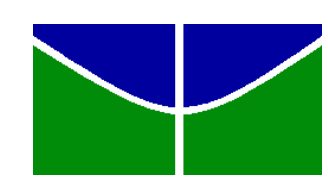

\author{
UNIVERSIDADE DE BRASÍLIA \\ FACULDADE DE EDUCAÇÃO \\ PROGRAMA DE PÓS-GRADUAÇÃO EM EDUCAÇÃO
}

JOSIMARA XAVIER

\title{
A FORMAÇÃO CONTINUADA DOCENTE NO ESPAÇO/TEMPO DA COORDENAÇÃO PEDAGÓGICA
}

\author{
Brasília - DF
}

Fevereiro de 2015 
JOSIMARA XAVIER

\section{A FORMAÇÃO CONTINUADA DOCENTE NO ESPAÇO/TEMPO DA COORDENAÇÃO PEDAGÓGICA}

Dissertação apresentada à Faculdade de Educação da Universidade de Brasília para obtenção do título de Mestre em Educação, sob a orientação da Prof ${ }^{a}$. Dra Cleide Maria Quevedo Quixadá Viana - UnB.

Linha de pesquisa: Profissão Docente, Currículo e Avaliação. 
Ficha catalográfica elaborada pela Biblioteca Central da Universidade de Brasília. Acervo 1020735.

Xavier, Josimara.

X3f A formação continuada docente no espaço/tempo da coordenação pedagógica / Josimara Xavier. - 2015. $166 \mathrm{f} . ; 30 \mathrm{~cm}$.

Dissertação (mestrado) - Universidade de Brasília, Faculdade de Educação, 2015.

Orientação: Cleide Maria Quevedo Quixadá Viana.

Inclui bibliografia.

1. Professores - Formação. 2. Educação permanente. I. Viana, Cleide Maria Quevedo Quixadá. II. Título.

CDU 371.13 


\section{A FORMAÇÃO CONTINUADA DOCENTE NO ESPAÇO/TEMPO DA COORDENAÇÃO PEDAGÓGICA}

Dissertação apresentada à Faculdade de Educação da Universidade de Brasília para obtenção do título de Mestre em Educação.

BANCA EXAMINADORA:

Prof $^{\mathrm{a}}$ Dr $^{\mathrm{a}}$ Cleide Maria Q. Quixadá Viana Orientadora - UnB/FE

Prof $^{a}$ Dr $^{a}$ Otília Maria A. da N. A. Dantas Examinadora Interna - UnB/FE
Prof $^{\mathrm{a}} \mathrm{Dr}^{\mathrm{a}}$ Ilma Passos Alencastro Veiga Examinadora externa - UnB/FE - UniCEUB

Prof $^{\mathrm{a}} \mathrm{Dr}^{\mathrm{a}}$ Shirleide Silva Cruz

Examinadora Interna Suplente - UnB/FE

Trabalho aprovado em:

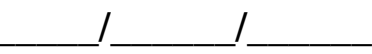


À Osmarina e Xavier, pais dedicados que desde pequena me ensinaram o que é integridade, honestidade, humildade e respeito. Foi com vocês que aprendi a lutar, a acreditar na possibilidade de viver em um mundo sem opressores e oprimidos, e a realizar sonhos.

Vó Dauta (in memorian), princípio de tudo. 


\section{AGRADECIMENTOS}

A Deus, pelos momentos de inspiração e graça, fortalecimento e fé.

Aos meus lindos, carinhosos e amados filhos, Filipe Xavier e Tiago Xavier pela compreensão, apoio e respeito às minhas escolhas e ausências. Por serem hoje, parte principal da minha vida. Por serem a minha escola. Com vocês, tenho aprendido a cada dia ser melhor.

A meu marido amigo, pelo apoio nos momentos que mais precisei. Também pelas divergências e discussões acaloradas que me fizeram fundamentar melhor meus argumentos, mas principalmente pelo incentivo e respeito às minhas posições filosóficas. Obrigada, Amorzão.

Aos meus irmãos consanguíneos: Daltinha, por compartilhar o conhecimento construído em anos de docência, supervisão e orientação pedagógica; Julinho, Deise, Vida, Vida Mírian, Tom, Marcos, Sérgio, Vladi, Jana, Sandra e Andréia, pelo incentivo, pelo amor! Por serem aguerridos em tudo que se dedicam, todos são bons exemplos para mim.

Aos meus irmãos escolhidos, Wanderson Quixadá e Kelly Barreto pelos almoços reflexivos, pelos sorrisos espontâneos, pelos trabalhos em grupo, pelas apreciações e conselhos, por compartilharem anseios e vitórias, por me permitirem amá-los do meu jeito.

Aos irmãos da crescente e feliz Família Quixadá: Aldinha, Ju, Marcos, Edu e Simone por compartilharem conhecimentos, produções, momentos de aprendizado e sorrisos.

À minha orientadora Cleide Quixadá por toda alegria, espontaneidade, jovialidade, por respeitar e valorizar a minha história de vida e trajetória profissional. Por me ver e me compreender na minha singularidade, limitações e potencialidades. Pela orientação rigorosa, mas sempre terna. Pela alegria constante. Por estabelecer uma relação de confiança, respeito, amizade e amor, e principalmente por acreditar que eu seria capaz me permitindo realizar, ao meu modo, o meu projeto de pesquisa. Levarei muito de ti, Queridona.

Aos professores do programa de Pós-Graduação da Faculdade de Educação da Universidade de Brasília, Lívia Borges, José Vieira, Carlos Alberto, Liliane Campos Machado, Wivian Weller por compartilharem conhecimentos importantes que contribuíram para minha aprendizagem e para o embasamento teórico dessa pesquisa. Levo-os em meu coração.

Às professoras Ilma Passos de Alencastro Veiga, Rosana César de Arruda Fernandes e Otília Dantas pelas contribuições durante o exame de qualificação e defesa de dissertação. 
Ao Grupo de Estudo e Pesquisa sobre Marxismo e Formação do Educador MarxEduca PPGE/PDCA/FE/UnB, pelos momentos de discussão e reflexão que me propiciaram compreender teoricamente o que ouvia desde pequena da boca dos meus pais sobre suas experiências "comunistas". Os encontros, as leituras e os diálogos favoreceram o conhecimento, a compreensão e o aprofundamento na teoria marxista.

À minha amiga, Elis Mundim, pelo incentivo, pela paciência e disponibilidade em ler meus textos, desde o pré-projeto. Pelas conversas produtivas e pelas construções colaborativas da prática docente. Pelos momentos de trabalho e de escrita árduos, mas também pelos momentos de conversas bobas e riso espontâneo. Elis, Mulher virtuosa, que sempre me acolheu, aconselhou, zelou e orou por mim. Deus te abençoe!

Ao OBEDUC, espaço de pesquisa e de aprendizagem que me possibilitou ampliar horizontes. Às professoras Carmem Tacca e Cristina Madeira pelo acolhimento e por contribuírem grandemente para a minha constituição docente com a possibilidade da pesquisa no "chão da escola", pelas leituras, pelos estudos e pelos momentos de confraternização e afeto sincero.

A todas as amigas do OBEDUC que de uma maneira ou de outra contribuíram para minhas reflexões e minha prática. Em especial às meninas da Equipe do Guará: Elis Mundim, Cíndia Carpina, Cris Clussner e Rejane Lúcia que amam educar e se preocupam em realizar um trabalho colaborativo. Aprendi muito com vocês!

Aos alunos de graduação das turmas de Didática pelas discussões que oportunizaram inúmeras reflexões e fortaleceram o meu amor pela docência.

Às minhas amigas da Secretaria de Educação, Aldenice Solino e Márcia Brants por todos os momentos que precisei e sempre obtive ajuda, apoio. Eterna gratidão.

À querida Sandra Campêlo pela ajuda no momento de tensão. Você é incrível!

Aos meus colegas de trabalho, pelo respeito, pela riqueza das conversas e pela troca de saberes.

Aos interlocutores das escolas pesquisadas por confiarem nesta pesquisa.

Enfim, a todos que tive a oportunidade e o prazer de conviver, aprender, pensar, refletir e que de algum modo contribuíram para a realização desse trabalho. 
Tudo tem o seu tempo determinado, e há tempo para todo o propósito debaixo do céu.

Há tempo de nascer, e tempo de morrer; Tempo de plantar, e tempo de arrancar o que se plantou;

Tempo de matar, e tempo de curar; Tempo de derrubar, e tempo de edificar; Tempo de chorar, e tempo de rir; Tempo de prantear, e tempo de dançar; Tempo de espalhar pedras, e tempo de ajuntar pedras; Tempo de abraçar, e tempo de afastar-se de abraçar; Tempo de buscar, e tempo de perder; Tempo de guardar, e tempo de lançar fora;

Tempo de rasgar, e tempo de coser; Tempo de estar calado, e tempo de falar;

Tempo de amar, e tempo de odiar;

Tempo de guerra, e tempo de paz. Que proveito tem o trabalhador naquilo em que trabalha?

Tenho visto o trabalho que Deus deu aos filhos dos homens, para com ele os exercitar. Tudo fez formoso em seu tempo; também pôs o mundo no coração do homem, sem que este possa descobrir a obra que Deus fez desde o princípio até ao fim.

Já tenho entendido que não há coisa melhor para eles do que alegrar-se e fazer bem na sua vida; E também que todo o homem coma e beba, e goze do bem de todo o seu trabalho; isto é um dom de Deus.

Eclesiastes 3:1-13 


\section{RESUMO}

A formação continuada docente no espaço/tempo da coordenação pedagógica é o tema central desse trabalho. Busca-se contribuir para a ampliação do debate sobre a importância o fortalecimento da temática em uma perspectiva emancipadora. Tem-se por objetivo central analisar as contribuições que a formação continuada docente desenvolvida pelos coordenadores pedagógicos locais no espaço/tempo da coordenação pedagógica oferece aos professores dos anos iniciais de duas escolas rurais da Rede Pública de Ensino do DF. De forma específica busca-se: analisar as influências e implicações dos aspectos históricos, sóciopolíticos e culturais na formação continuada dos professores dos anos iniciais do DF no contexto atual; analisar as concepções de formação continuada dos coordenadores locais e dos professores regentes; discutir as estratégias de formação empreendidas pelos coordenadores pedagógicos dos anos iniciais no espaço/tempo da coordenação pedagógica; analisar as perspectivas/concepções das estratégias da formação continuada que se fazem presentes no espaço/tempo da coordenação pedagógica dos professores dos anos iniciais. São eixos orientadores do percurso: o trabalho como fundamento do processo formativo; a formação continuada docente como possibilidade emancipadora e a formação no espaço/tempo da coordenação pedagógica como possibilidade de mudança ou de perpetuação da ideologia dominante. Trata-se de um estudo de caso múltiplo na abordagem qualitativa, realizado no primeiro semestre de 2014. Os interlocutores foram duas diretoras, duas coordenadoras pedagógicas locais e vinte e dois professores regentes. Os instrumentos utilizados para a coleta de dados foram: observação; complemento de frases; entrevista e questionário. A pesquisa de natureza teórico-prática utilizou-se da análise documental e da pesquisa bibliográfica. A fundamentação teórica apoia-se em Marx (1983); Saviani (1988, 2002); Saviane e Duarte (2012); Tonet (2005a, 2005b); Lessa e Tonet (2008); Veiga (2012); Veiga e Quixadá Viana (2012); Fernandes (2012); Zeichner (1998); Placco e Silva (2011); Soares (2012); Lima (2013), dentre outros. Verifica-se que o espaço/tempo da coordenação pedagógica é privilegiado para a formação continuada docente, assim, sua importância e organização não podem ser ignoradas; esse espaço/tempo pode favorecer o desenvolvimento pedagógico e docente. Sua estrutura atual favorece a formação continuada docente na escola a partir de suas reais necessidades, todavia ainda são muitos os desafios a serem enfrentados como a pouca valorização da conquista desse espaço/tempo, a falta de formação continuada do próprio coordenador pedagógico, pelo não reconhecimento da figura do coordenador 
pedagógico como formador, a pouca conscientização do coordenador da necessidade de se constituir como sujeito no seu espaço de atuação. Espera-se que as reflexões suscitadas a partir desse trabalho contribuam para a constituição do espaço/tempo da coordenação pedagógica como campo de uma formação continuada docente embasada na práxis como possibilidade de transcender os marcos do capital.

Palavras-chave: Trabalho como princípio educativo. Trabalho docente. Formação continuada. Coordenação pedagógica. 


\begin{abstract}
The teacher continued education in space / time teaching coordination is the central theme of this work. The aim is to contribute to the expansion of the debate on the importance of strengthening the subject in an emancipatory perspective. It has been a central goal analyze the contributions that the teaching continuing education developed by local coordinators in space / time teaching coordination offers teachers the early years of two rural schools Public Network of the Federal District Education. To achieve this goal, were drawn also specific objectives: to analyze the influences and implications of the historical, socio-political and cultural in the continuing education of teachers in the early years of the Federal District in the current context; analyze the conceptions of ongoing training of local coordinators and school teachers; discuss training strategies undertaken by the coordinators of the early years in space / time teaching coordination; analyze the prospects / conceptions of the strategies of continuing education that are present in the space / time of the pedagogical coordination of the early years teachers. It is used as guiding axes of the route: work as a foundation for the training process; teacher continuing education as emancipatory possibility and training in space / time teaching coordination as a possibility for change or perpetuation of the dominant ideology. This is a multiple case study in the qualitative approach, which was held in the first semester of 2014. The interlocutors were two directors, two local pedagogical coordinators and twenty-two school teachers. The instruments used to collect data were observation, the complement of sentences, the interview and the questionnaire. The research of theoretical and practical nature made use of document analysis and literature. The theoretical foundation is supported by Marx (1983); Saviani (1988, 2002); Saviane and Duarte (2012); Tonet (2005a, 2005b); Lessa and Tonet (2008); Veiga (2012); Veiga e Quixadá Viana (2012); Fernandes (2012); Zeichner (1998); Placco and Silva (2011); Soares (2012); Lima (2013), among others. It appears that the space / time of teaching coordination is privileged for teacher continuing education, so their importance and your organization can not be ignored, since their recovery work in this space / time will favor the pedagogical development, development teaching and the development of postures that seek to transform the social context. Its current structure favors the teacher continuing education within the school from the real needs of the school community, however there are still many challenges that are configured for this space / time to materialize its broad possibilities, especially for the little achievement to valorize this space / time, lack of continued education of own pedagogical coordinator, not to recognize the
\end{abstract}


figure of the pedagogical coordinator and trainer, passing by the still little awareness of own coordinator of the need to be as a subject in their sphere of action. It is expected that the thinking generated from this work will contribute to the formation of the space / time of teaching coordination as a field of teaching continuing education grounded in praxis as possibility of transcending the capital's landmark.

Keywords: Work as an educational principle. Teaching. Continuing education. Teaching coordination. 


\section{LISTA DE QUADROS}

Quadro 1 - Outras questões e objetivos específicos da pesquisa ......................................... 17

Quadro 2 - Tempo destinado à Coordenação Pedagógica nas UE de Anos Iniciais................ 65

Quadro 3 - Quadro de Quantidade de Supervisores Pedagógicos por UE..............................69

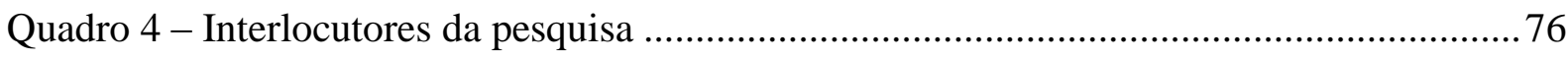

Quadro 5 - Organização do trabalho pedagógico nas UE's segundo os interlocutores.............96 


\section{LISTA DE SIGLAS}

BIA Bloco Inicial de Alfabetização

CEAM Centro de Estudos Avançados Multidisciplinares

CFE Conselho Federal de Educação

CFORM Centro de Formação Continuada de Professores

CNE Conselho Nacional de Educação

CRE Coordenação Regional de Ensino

CP Coordenadora Pedagógica

DF Distrito Federal

DR Diretora

EAPE Escola de Aperfeiçoamento dos Profissionais de Educação

EJA Educação de Jovens e Adultos

FEDF Fundação Educacional do Distrito Federal

LDB Lei de Diretrizes e Bases da Educação

PNAIC Pacto Nacional pela Alfabetização na Idade Certa

PPP Projeto Político Pedagógico

PR Professor Regente

SINPRO-DF Sindicato dos Professores do Distrito Federal

SEEDF Secretaria de Estado de Educação do Distrito Federal

OBEDUC Observatório da Educação

UE Unidade Escolar

UnB Universidade de Brasília 


\section{SUMÁRIO}

1 INTRODUÇÃ

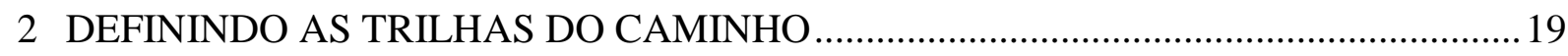

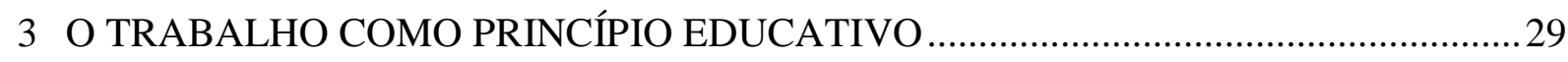

3.1 Trabalho docente: Intelectual? Prático? Onde fica a práxis? ......................................31

3.2 O sentido da escola e o trabalho pedagógico......................................................................36

4 FORMAÇÃO CONTINUADA DOCENTE: um contexto de contradições ........................ 40

4.1 A Formação continuada como possibilidade de emancipação docente .........................44

4.2 A formação continuada por dentro da escola ...................................................................47

5 A FORMAÇÃO CONTINUADA DOCENTE NO ESPAÇO/TEMPO DA

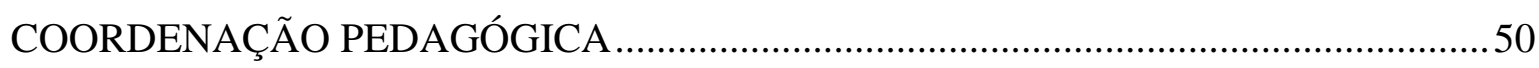

5.1 Um olhar histórico sobre a coordenação pedagógica: perspectiva histórica ...............52

5.2 A Coordenação Pedagógica no Distrito Federal .............................................................59

5.3 O Coordenador Pedagógico e seu papel formador......................................................71

6 O ESPAÇO/TEMPO DA COORDENAÇÃO PEDAGÓGICA E A FORMAÇÃO CONTINUADA DOCENTE: ANÁLISE DO DITO, VISTO E VIVIDO ..........................74

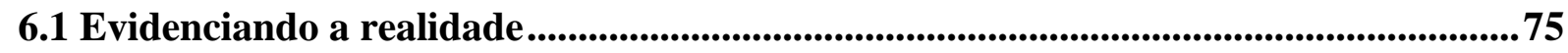

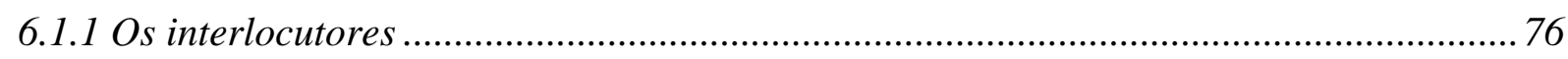

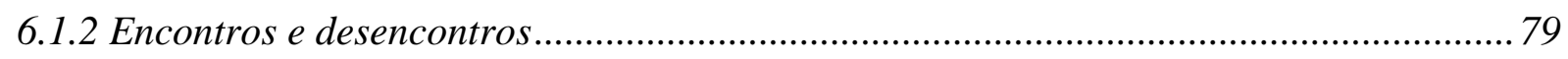

6.1.3 A estrutura física e o reflexo na organização do trabalho pedagógico ........................... 82

6.2 O espaço e o tempo da coordenação pedagógica: as ações, espelho das concepções ..95

6.2.1 A formação continuada: o ideal e o real......................................................................... 95

6.2.2 A formação continuada e a formação do formador ....................................................... 98

6.2.3 A formação continuada e a constituição do sujeito coordenador .................................. 102

6.2.4 A formação continuada e o desafio de fortalecer o espaço/tempo da coordenação

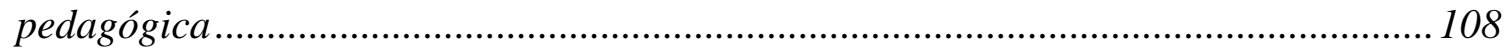

6.2.5 A Formação continuada e o desafio de fortalecê-la no espaço/tempo da coordenação

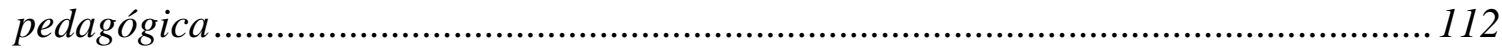

6.2.6 A formação continuada e a filosofia da práxis.......................................................... 116

6.2.7 A formação continuada e o desafio de superar o trabalho individualizado .................. 120

6.2.8 A formação continuada e a constituição da identidade das UE's ................................. 122

6.2.9 A formação continuada e o desafio da organização do trabalho pedagógico............... 125

7 A CHEGADA... REFLEXÕES SOBRE OS ACHADOS NO CAMINHO ......................131 
APÊNDICE A - Termo de consentimento livre e esclarecido................................................ 146

APÊNDICE B - Roteiro para entrevista do coordenador pedagógico...............................147

APÊNDICE $\mathrm{C}-1^{\circ}$ questionário aberto para professores regentes..................................149

APÊNDICE D - $2^{\circ}$ questionário aberto para professores regentes...................................150

APÊNDICE $E-3^{\circ}$ questionário aberto para professores regentes e $2^{\circ}$ questionário aberto para coordenadoras pedagógicas

APÊNDICE F - Complemento de frases para professores regentes e coordenadoras pedagógicas

APÊNDICE $G-1^{\circ}$ questionário aberto para coordenadoras pedagógicas 154

APÊNDICE $\mathrm{H}-3^{\circ}$ questionário aberto para coordenadores pedagógicos 156

APÊNDICE I - Questionário aberto para diretoras 158

ANEXOS

ANEXO A - Quadro de Planejamento Quinzenal UE 02. 160

ANEXO B - Quadro de Planejamento Semestral - Matemática/UE 02. 161

ANEXO C - Quadro de Acompanhamento de aluno - Matemática/UE 02 162

ANEXO D - Quadro de Acompanhamento de aluno - Matemática/UE 02 163

ANEXO E - Quadro de Acompanhamento de aluno - Língua Portuguesa/UE 02 164

ANEXO F - Formulário para registro de reunião pedagógica UE 01 165 


\section{INTRODUÇÃO}

O fortalecimento da formação continuada docente no espaço/tempo da coordenação pedagógica tem sido objeto de investigação e discussão de vários pesquisadores, fato que a tem tornado expressiva na esfera educacional.

Acredito que a coordenação pedagógica, embora apresentando características fundamentadas no modelo da racionalidade técnica, é importante para a concretização dos processos de aprendizagem docentes em diferentes níveis, porque possibilita aos professores a reflexão sobre o próprio trabalho; valorizá-lo; identificar as teorias que o embasam; a análise e a crítica de suas próprias práticas, além de favorecer o compartilhamento de experiências e a proposição de superação das dificuldades que se apresentam na busca pela transformação da realidade na qual atuam.

Nesse sentido, Imbernón afirma que a formação é um processo que aparentemente começa na prática, mas na verdade começa "da práxis, já que a experiência prática possui uma teoria, implícita ou explícita, que a fundamenta" (2010, p. 37) e o professor, a partir da análise de sua prática, em meio a muitas ponderações fará escolhas que determinam sua ação e isso seria a concretização do seu processo formativo.

Esse processo considera o professor em sua condição de sujeito, aquele que “constrói, produz e transforma os instrumentos da sua prática, conhecimentos, modos de ação técnica, linguagem, valores, sentimentos, entre outros aspectos" (CARNEIRO; SILVA, 2008, p. 139), explicitando que a aprendizagem está intrinsecamente relacionada com o conjunto de fatores que constituem e são constituídos pela história humana.

Esse é o grande desafio da formação docente, relacionar teorias às experiências dos professores para que a aprendizagem interfira de forma positiva nas ações desses sujeitos que poderão ressignificar as dimensões pessoal, profissional e social, impelindo-os à “intervenção crítica, comprometida e intencional num determinado espaço social historicamente situado, a fim de que se realize um trabalho pedagógico voltado para a formação humana" (CARNEIRO; SILVA, 2008, p. 139).

Levando em conta tal perspectiva é que apresento minha proposta de pesquisa, apoiada nos pressupostos da pesquisa qualitativa, trazendo um estudo de caso múltiplo, o qual me possibilitou investigar o contexto histórico e social da formação continuada docente no espaço e no tempo da coordenação pedagógica, opção justificada pela possibilidade de 
apreendermos as determinações sociais mais amplas das condições de existência dos sujeitos da pesquisa (MINAYO, 2011).

Meu interesse por esse tema despontou a partir da minha experiência como coordenadora em uma escola de uma Coordenação Regional de Ensino - CRE, da rede pública do Distrito Federal, mas de fato se consolidou durante um curso de especialização lato sensu em Coordenação Pedagógica realizado por meio de convênio firmado entre a Secretaria de Estado de Educação do Distrito Federal - SEEDF e a Reitoria da Universidade de Brasília - UnB, via Centro de Estudos avançados Multidisciplinares - CEAM, pela Coordenação de Formação Continuada - CFORM.

O referido curso provocou em mim muitos questionamentos sobre as limitações da coordenação pedagógica, mas também revelou as possibilidades que a formação continuada docente no próprio local de trabalho pode apresentar. Nesse sentido, elegi como objeto de pesquisa a formação continuada docente desenvolvida no espaço/tempo da coordenação pedagógica em duas escolas rurais de uma CRE - SEEDF.

Nesse contexto surgiu a questão central na qual defini o problema da pesquisa: Quais são as contribuições que a formação continuada docente desenvolvida pelos coordenadores pedagógicos locais no espaço/tempo da coordenação pedagógica oferece para a formação do professor dos anos iniciais?

A partir da questão central, apresento o objetivo geral do presente estudo:

- Analisar a proposta de formação continuada docente desenvolvida pelos coordenadores pedagógicos locais no espaço/tempo da coordenação pedagógica e sua contribuição para a formação dos professores dos anos iniciais.

Além da questão central, outras questões também foram levantadas para melhor compreensão do meu objeto de estudo e a partir delas surgiram objetivos específicos como os apresentados a seguir: 
Quadro 1 - Outras questões e objetivos específicos da pesquisa

\begin{tabular}{|l|l|}
\hline \multicolumn{1}{|c|}{ OUTRAS QUESTÕES } & \multicolumn{1}{|c|}{ OBJETIVOS ESPECÍFICOS } \\
\hline $\begin{array}{l}\text { Quais as influências e implicações dos aspectos } \\
\text { históricos, sócio-políticos e culturais na formação } \\
\text { continuada dos professores dos anos iniciais do DF no } \\
\text { contexto atual? }\end{array}$ & $\begin{array}{l}\text { Analisar as influências e implicações dos aspectos } \\
\text { históricos, sócio-políticos e culturais na formação } \\
\text { continuada dos professores dos anos iniciais do } \\
\text { Distrito Federal no contexto atual. }\end{array}$ \\
\hline $\begin{array}{l}\text { Quais as concepções de formação continuada dos } \\
\text { coordenadores locais e dos professores regentes? }\end{array}$ & $\begin{array}{l}\text { Analisar as concepções de formação continuada dos } \\
\text { coordenadores locais e dos professores regentes. }\end{array}$ \\
\hline $\begin{array}{l}\text { Quais são as estratégias de formação empreendidas } \\
\text { pelos coordenadores pedagógicos dos anos iniciais no } \\
\text { espaço/tempo da coordenação pedagógica? }\end{array}$ & $\begin{array}{l}\text { Discutir as estratégias de formação empreendidas } \\
\text { pelos coordenadores pedagógicos dos anos iniciais no } \\
\text { espaço/tempo da coordenação pedagógica. }\end{array}$ \\
\hline $\begin{array}{l}\text { Que concepção de formação continuada se faz } \\
\text { presente no espaço/tempo da coordenação pedagógica } \\
\text { dos professores dos anos iniciais? }\end{array}$ & $\begin{array}{l}\text { Analisar as perspectivas/concepções das estratégias da } \\
\text { formação continuada que se fazem presentes no } \\
\text { espaço/tempo da coordenação pedagógica dos } \\
\text { professores dos anos iniciais. }\end{array}$ \\
\hline
\end{tabular}

Fonte: Elaborado pela autora. Pesquisa de mestrado, 2015.

Considerando a complexidade das situações enfrentadas hoje nas escolas com a fragmentação dos processos de trabalho, de ensino, de formação, entendi a importância de partir de uma sólida fundamentação teórica sobre a concepção de trabalho como princípio educativo e sua relação com a educação. Nesse sentido, me apoio em Marx (1983) e em autores que discutem a relação trabalho e educação a partir da ótica marxista, como, Mello (1982), Mészáros (2012); Saviani (2002), Sousa (2012), Souza Júnior (1999), entre outros. Na discussão sobre a formação docente continuada como possibilidade emancipadora trago, Veiga (2012), Veiga e Quixadá Viana (2012), Fernandes (2012), Zeichner (1998), Tonet (2005a, 2005b), Lessa e Tonet (2008), entre outros, como também a discussão de autores que tratam do tema espaço/tempo da coordenação pedagógica como possibilidade de transformação da realidade educacional: Placco e Silva (2011), Soares (2012), Saviani (1988), Lima (2013), Fernandes (2012), entre outros.

Organizei o estudo utilizando como eixos orientadores do percurso: o trabalho como fundamento para o processo formativo; a formação continuada docente como possibilidade emancipadora e a formação no espaço/tempo da coordenação pedagógica como possibilidade de fortalecimento ou de rompimento com a ideologia capitalista.

No segundo capítulo, "Definindo as trilhas do caminho", justifico a minha opção pela pesquisa qualitativa, a partir do estudo de caso múltiplo por se tratar de duas unidades escolares e pela possibilidade de captar o fenômeno em sua essência, no seu próprio contexto.

No terceiro capítulo, "O trabalho como princípio educativo", parto da concepção de trabalho na perspectiva marxista, para a compreensão de questões que envolvem o fundamento da formação do homem como ser social, a natureza do trabalho docente, o 
sentido social da escola e o trabalho pedagógico nela desenvolvido que definem o fazer docente e contribuem para a constituição do ser professor.

No quarto capítulo, "A formação continuada docente: um contexto de contradições" discuto a formação continuada do docente, seus objetivos, suas finalidades e as possibilidades dessa formação se dar em uma perspectiva emancipatória, mesmo em um contexto de contradições protagonizadas pela ideologia dominante.

No quinto capítulo, "A formação continuada docente no espaço/tempo da coordenação pedagógica", abordo as questões políticas e históricas que marcaram a constituição da função do coordenador pedagógico e as determinações do seu fazer e apresento o cenário no qual se organiza a coordenação pedagógica nas escolas da Secretaria de Estado de Educação do DF, analisando a função formadora do coordenador pedagógico na escola.

Nesse percurso, identifiquei fragilidades, conflitos, tensões e contradições da formação continuada docente que acontece no espaço e no tempo da coordenação pedagógica, mas também vislumbrei inúmeras possibilidades de transcendência dessas mesmas limitações e seu potencial para abrigar discussões, reflexões e ações transformadoras de concepções e de práticas visando à transformação social.

Nas minhas considerações aponto para a necessidade de, por meio de uma visão crítica, se repensar a formação continuada docente que acontece no espaço/tempo da coordenação pedagógica, a formação continuada do coordenador pedagógico, assim como repensar também a organização desse espaço/tempo para que ele de fato se configure como possibilidade de superação das limitações de uma formação continuada docente descontextualizada e fragmentada.

É oportuno destacar que com esta pesquisa não busquei limitar a discussão das contribuições que a formação continuada docente no espaço e no tempo da coordenação pedagógica da rede pública do Distrito Federal pode oferecer à prática do professor, mas, antes, proponho a ampliação do debate acerca da formação continuada docente que acontece dentro da escola, em estreita relação com o trabalho como princípio educativo e no confronto de concepções que analisam o desenvolvimento profissional docente no contexto das relações sociais estruturadas pela ordem social vigente. 


\section{DEFININDO AS TRILHAS DO CAMINHO}

Existem muitos questionamentos em relação à produção de conhecimento científico na busca por conhecer o mundo real. Tal fato se dá porque há diferentes correntes do pensamento contemporâneo que desenvolvem suas teorias a respeito dessa problemática e caminham separadamente na intenção de avançar nas maneiras de se conhecer o objeto pesquisado.

Em meio a essa diversidade de correntes de pensamento e segundo Triviños (2012), diante da fraqueza intelectual do pesquisador, tem havido de forma recorrente a incoerência entre o arcabouço teórico e as práticas que este realiza. Essa fraqueza tem sido explicitada nos trabalhos científicos que trazem uma miscelânea de pensamentos filosóficos e citações fora do contexto. O citado autor, com essa afirmação, não rejeita a possibilidade de haver um diálogo entre os pensamentos, ideias e conceitos filosóficos diferentes e afirma que

\footnotetext{
Estamos conscientes de que o investigador pode usar em seus trabalhos conceitos que tenham as suas raízes em ideologias divergentes, inclusive, opostas. [...] As aquisições do ser humano pertencem à humanidade. $\mathrm{O}$ homem pode recorrer a elas não importando seu lugar intelectual no cosmos. Mas o pesquisador, por coerência, por disciplina, deve ligar a apropriação de qualquer ideia à sua concepção de mundo, em primeiro lugar, e, em seguida, inserir essa noção no quadro teórico específico que lhe serve de apoio para o estudo dos fenômenos sociais. (TRIVIÑOS, 2012, p. $13)$.
}

Trazendo para a minha realidade de pesquisa que é a formação continuada docente no espaço/tempo da coordenação pedagógica, ou seja, a formação continuada que acontece no próprio local de trabalho, senti a necessidade de fundamentá-la a partir de pressupostos que viessem favorecer o estabelecimento de uma compreensão mais esclarecedora sobre a formação docente na perspectiva do trabalho como princípio educativo, assim como favorecer a reflexão a respeito da necessidade de superação de práticas reprodutivistas do modelo tradicional de ensino e da superação da dicotomia teoria e prática, na constituição da práxis.

Logo, me apoiei também em pesquisadores que trabalham na perspectiva emancipatória do professor, Mello (1982); Saviani (1988, 2002); Saviani e Duarte (2012); Tonet (2005a; 2005b); Lessa e Tonet (2008); Veiga (2012); Veiga e Quixadá Viana (2012); Fernandes (2012); Zeichner (1998); para embasar minha reflexão a respeito da sua condição de sujeito ativo no contexto sócio-político-econômico, capaz de ressignificar sua prática a 
partir da produção de conhecimentos críticos que possibilitem mudanças de concepções e os coloquem no caminho para a emancipação do gênero humano.

Desse modo, considero que o delineamento da metodologia por mim adotado fundamentou as etapas da pesquisa de forma que estas, ao serem concretizadas, constituíramse em parte essencial para que os objetivos propostos inicialmente fossem atingidos.

Pelas razões expostas, optei por pautar a pesquisa na abordagem qualitativa devido à natureza do estudo que pretendi desenvolver. Quando me propus a compreender o problema da pesquisa, minha intenção foi a de manter uma relação significativa entre a questão a ser pesquisada e os pressupostos da pesquisa qualitativa. Trabalhando nessa perspectiva, Lüdke e André apontam cinco características básicas deste tipo de pesquisa:

1. A pesquisa qualitativa tem o ambiente natural como sua fonte direta de dados e o pesquisador como seu principal instrumento.

2. Os dados coletados são predominantemente descritivos.

3. A preocupação com o processo é muito maior do que com o produto.

4. O significado que as pessoas dão às coisas e à sua vida são focos de atenção especial pelo pesquisador.

5. A análise dos dados tende a seguir um processo indutivo. (LÜDKE; ANDRÉ, 1986, p. 11).

Considerando as cinco características acima citadas, constato que a partir de uma abordagem qualitativa, o pesquisador não se deterá ao simples registro da frequência com que acontecem os fenômenos no ambiente pesquisado. Ele irá além, no intuito de fazer a análise dos elementos do seu objeto de investigação, propondo reflexões que gerem o posicionamento crítico dos envolvidos.

Esse posicionamento crítico produzirá novas reflexões e gerará a busca por novos conhecimentos. Acredito que o conhecimento não nasce do isolamento ou da individualidade dissociada de um contexto, mas tem um caráter social, nasce a partir da interação histórica entre os seres. Os participantes e o pesquisador produzirão parcela significativa de conhecimento que contribuirá para a emancipação humana e para a evolução da sociedade.

Esta emancipação fundamenta-se não nos marcos do sistema capitalista, mas como aponta Tonet (2005a), no princípio de combater a lógica que preside fundamentalmente a sociabilidade regida pelo capital buscando a transformação radical da sociedade tendo como base a racionalidade do trabalho na busca de uma sociabilidade verdadeiramente livre, na qual os indivíduos ao realizarem suas objetivações comuns ao gênero humano poderão construir-se como membros deste gênero. 
Dessa forma, pensando na educação, me deparo com a riqueza da oportunidade de pesquisar o fenômeno em seu ambiente real, em um contexto específico, de conhecer a realidade do ambiente pesquisado e a importância dos elementos contextuais que são fundamentais para a pesquisa de relevante caráter social.

Ademais, acredito que das minhas conclusões emergirão respostas que buscarão apresentar o contexto do como e por que o fenômeno da formação, das relações e do aprendizado docente se concretizará daquela forma, naquele ambiente, naquele momento histórico.

Em relação à pesquisa qualitativa, Triviños (2008, p. 124) defende que os fatores que ajudam a delimitar a definição qualitativa de uma pesquisa são "as bases teóricas do pesquisador”. Ampliando a justificativa da abordagem escolhida, afirmo que o objeto a ser pesquisado me remeteu a esta abordagem por permitir a reunião de um conjunto de técnicas interpretativas a partir da percepção da especificidade do fenômeno visto naquele dado momento histórico e no contexto específico.

$\mathrm{Na}$ abordagem qualitativa segue-se uma rota metodológica ao ser realizada a investigação e na perspectiva de revelar o objeto, optei pelo estudo de caso como procedimento metodológico que, de acordo com Gil (2009) é um delineamento de pesquisa que investiga o fenômeno contemporâneo sem retirá-lo de seu contexto, preservando o seu caráter unitário utilizando diversos métodos ou técnicas de coleta de dados, como, por exemplo, a observação, a entrevista e a análise documental.

Mesmo não apresentando rigidez dos levantamentos e experimentos, o estudo de caso é rigoroso, pois envolve etapas que requerem tempo e sensibilidade do pesquisador para lidar diretamente com os sujeitos pesquisados e as situações reais no ambiente natural da pesquisa.

Considerando que "a pesquisa do estudo de caso inclui tanto estudos de caso único quanto de casos múltiplos" (YIN, 2010, p. 41), considerando ainda a minha escolha e as características apontadas, posso afirmar que o caso estudado é múltiplo, assim como são os resultados alcançados nos contextos da pesquisa, dos quais tirei um conjunto de conclusões e fiz o cruzamento de dados ${ }^{1}$.

Com esse estudo de caso múltiplo e lançando mão da lógica da replicação literal e teórica, evidencio os resultados exemplares obtidos a partir das investigações, na busca pelas respostas às questões de pesquisa. Dentre tantos motivos optei por realizar um estudo de caso

\footnotetext{
1“Cross-case”, segundo Yin (2010, p. 42).
} 
múltiplo porque o estudo de caso único pode ser vulnerável, como afirma Yin (2010). Ele, ainda, acrescenta que "possuir dois casos pode começar a reduzir as críticas e o ceticismo" (YIN, 2010, p. 86), o que leva a crer que, dessa forma, o estudo será fortalecido tornando os achados mais vigorosos.

Escolhi duas instituições públicas, de educação básica da SEEDF, localizadas em área rural. As duas escolas atendem alunos que moram em núcleos rurais próximos. A maioria dos estudantes atendidos mora em regiões que não possuem infraestrutura adequada como outras escolas públicas, praças, hospitais, saneamento básico, transporte público que atenda a demanda.

Uma das escolas possui 10 turmas desde a educação infantil ao $5^{\circ}$ ano dos anos iniciais, funcionando apenas no diurno e a outra atende a 45 turmas desde a educação infantil ao ensino médio, funcionando no diurno com ensino regular e no noturno com ensino médio regular e os três segmentos da $\mathrm{EJA}^{2}$.

Para Triviños (2008), em uma pesquisa, geralmente, há uma relação entre o problema de pesquisa, objetivos e público-alvo. Em outras palavras, o que definiu meu público-alvo foram os objetivos de pesquisa, pois necessariamente, precisei trazer à tona as opiniões e declarações dos coordenadores e dos professores das escolas pesquisadas sobre as questões que a pesquisa se dispôs responder.

Participaram dessa pesquisa de forma voluntária (Apêndice A), duas diretoras, duas coordenadoras pedagógicas dos anos iniciais e vinte e duas professoras regentes que atuam do primeiro ao quinto ano. Tais sujeitos foram escolhidos porque trabalham naqueles ambientes de maneira ampla e singular me possibilitando compreender o fenômeno a ser pesquisado à luz das práticas por eles desenvolvidas.

Partindo das concepções epistemológicas da pesquisa qualitativa e visando uma produção de análise qualificada, utilizei instrumentos de embasamento teórico que se complementam, privilegiando as relações dialógicas e dando apoio à análise dos dados obtidos, evitando que as considerações de análise se estabeleçam apenas a partir do pensamento empírico do próprio pesquisador.

No meu caso, trouxe como fonte de recurso para auxiliar a estratégia de análise geral, a pesquisa bibliográfica. Ela serviu de base teórica para a análise do objeto da pesquisa nos aspectos históricos, sócio-políticos e culturais tornando claras as implicações destes na

\footnotetext{
${ }^{2}$ A Educação de Jovens e Adultos - EJA é dividida em três segmentos nos quais o $1^{\circ}$ corresponde aos anos iniciais, o $2^{\circ}$ aos anos finais do Ensino Fundamental e o $3^{\circ}$ segmento corresponde ao Ensino Médio. Cada segmento é subdividido em etapas e cada etapa é cursada semestralmente.
} 
instituição do espaço/tempo da coordenação pedagógica como destinado para a formação continuada docente.

Neste levantamento, com a intenção de caracterizar melhor o caso, identifiquei produções científicas de diversos autores que já investigaram experiências de desenvolvimento profissional docente no tempo/espaço da coordenação pedagógica nas escolas públicas.

Segundo Gil, a revisão de literatura bem elaborada contribui para:

(1) centrar e refinar o problema, (2) indicar o estágio atual de conhecimento em relação ao tema; (3) proporcionar o estabelecimento de um sistema conceitual coerente; (4) identificar contribuições teóricas aplicáveis ao estudo; (5) verificar os métodos de investigação utilizados por outros pesquisadores para investigar o tema; (6) identificar possíveis resultados contraditórios na investigação prévia. (GIL, 2009, p. 47).

Como fonte de evidência, recorri à pesquisa documental, pois de acordo com Yin (2010), "para os estudos de caso, o uso mais importante dos documentos é para corroborar e aumentar a evidência de outras fontes". Nesse sentido, Gil (2009, p. 76) acrescenta que "a consulta a fontes documentais é imprescindível em qualquer estudo de caso", pois se constitui como fonte importante de complementação a outros instrumentos de coleta de dados tais como a entrevista e o questionário.

Dessa forma, fiz uso da legislação vigente e de documentos oficiais que versam sobre a formação continuada do docente, a formação no espaço/tempo da coordenação pedagógica, implantação/implementação da coordenação pedagógica como espaço de formação continuada do docente e dos percursos desta no Distrito Federal, pois creio que tais documentos se constituem como importante fonte de informações a respeito das políticas públicas do DF.

Outra fase importante da pesquisa foi a de coleta dos dados. Afinal, é nessa fase e a partir da utilização adequada dos instrumentos de coleta que tratei do problema a partir do estabelecimento da relação entre o referencial teórico, a metodologia e os dados.

Para tanto, utilizei as entrevistas semiestruturadas (Apêndice B) com as coordenadoras das duas instituições responsáveis pela formação docente no espaço/tempo da coordenação pedagógica, buscando compreender o trabalho de formação continuada que tem sido desenvolvido junto aos professores. 
Entrevistei as duas coordenadoras locais ${ }^{3}$, que compõem a equipe formadora, uma de cada instituição de ensino e a partir das entrevistas busquei compreender as suas concepções de formação continuada, as estratégias de formação empreendidas por elas nos anos iniciais no espaço/tempo da coordenação pedagógica, bem como em que perspectiva/concepção a formação se faz presente no espaço/tempo da coordenação pedagógica dos professores regentes dos anos iniciais.

A esse respeito, Triviños (2008, p. 145) afirma que "a entrevista semiestruturada é um dos principais meios que tem o investigador para realizar a Coleta de Dados". Por sua vez, Gil (2009, p. 63) acrescenta que "a entrevista é uma técnica eficiente para a obtenção de dados em profundidade acerca dos mais diversos aspectos da vida social" e por seu caráter valioso, tem sido utilizada em muitos estudos de caso.

Na perspectiva de compreender de maneira mais aprofundada os fenômenos que me propus investigar e tendo a clareza dos meus objetivos, os quais nortearam e delimitaram o percurso, fiz a análise e exploração do material coletado para interpretação.

Após as entrevistas, fiz a transcrição literal para análise do conteúdo buscando dar visibilidade e sentido ao que o sujeito pretendeu transmitir buscando relacionar ao contexto sócio-histórico, pois segundo Bardin (2011), todo dizer traz marcas ideológicas. Dessa maneira, o discurso das coordenadoras também traz em si o sentido, as marcas de suas histórias e das ideologias que representam.

Em outro momento, apliquei questionários que facilitaram a expressão da maior quantidade de informações possíveis por parte dos professores regentes das duas instituições que participam da formação desenvolvida pelos coordenadores pedagógicos no espaço/tempo da coordenação pedagógica. No decorrer da investigação e pela falta de elementos que deixassem claras as ações das coordenadoras pedagógicas, também elaborei um questionário para as próprias coordenadoras locais.

Os questionários tiveram perguntas abertas. Por meio deles, procurei analisar as concepções de formação dos professores, a visão dos professores sobre a formação continuada realizada nos momentos da coordenação pedagógica, o que eles pensam a respeito das propostas, ações e contribuições dos coordenadores locais para sua formação continuada.

O uso desse tipo de questionário se justifica porque "Um questionário consiste basicamente em traduzir os objetivos de pesquisa em questões específicas. As respostas a

\footnotetext{
${ }^{3}$ Coordenadores locais são os coordenadores que são lotados e atuam nas escolas. No Distrito Federal, também há a figura do coordenador intermediário que atua nas Coordenações Regionais de Ensino e os coordenadores centrais que atuam na SEEDF. Para maiores esclarecimentos, ver Regimento das escolas públicas do DF.
} 
essas questões é que irão proporcionar os dados requeridos para testar as hipóteses ou esclarecer o problema de pesquisa" (GIL, 2009, p. 129).

Gil comenta, ainda, que com o uso de questionários é possível observar as seguintes vantagens:

- economia de recursos materiais e humanos;

- possibilidade de atingir grande número de pessoas;

- atendimento ao ambiente pesquisa que é uma escola;

- minimização das possibilidades de distorções e de enviesamento oriundos da participação direta do pesquisados;

- mais segurança ao público-alvo em decorrência do anonimato. (GIL, 2009, p. 145).

Os questionários aplicados ao público-alvo previamente definidos (Apêndices $\mathrm{C}$, $\mathrm{D}, \mathrm{E}, \mathrm{G}$ e H), apresentaram questões abertas nas quais o esforço de abordar os elementos referentes à compreensão da coordenação pedagógica como espaço privilegiado para a formação docente nas escolas em questão foi uma constante.

Sobre as questões, estas foram formuladas com base no que diz Triviños (2008, p. 146) ao afirmar que “[...] elas são resultados não só da teoria que alimenta a ação do investigador, mas também de toda a informação que ele já colheu sobre o fenômeno social que interessa".

Além dos questionários, utilizei com o grupo de professores o complemento de frases (Apêndice F) com cinco indutores curtos que foram preenchidos pelos sujeitos. Essa opção se deu porque segundo González Rey (2005a, p. 57), “os indutores são de caráter geral e também podem referir-se a atividades, experiências, ou pessoas, sobre as quais queremos que o sujeito se expresse intencionalmente".

O complemento de frases foi organizado com frases incompletas que os participantes da pesquisa completaram com ideias próprias que foram surgindo ao longo do preenchimento. Ele foi entregue a cada professor e a duas coordenadoras após a apresentação do projeto de pesquisa para conhecimento dos interlocutores e do estabelecimento de vínculo tanto pelos objetivos traçados como pelo interesse ao tema da pesquisa. É importante destacar que tal instrumento possibilitou o levantamento de hipóteses sobre o tema estudado levando os interlocutores assumirem uma postura mais reflexiva diante do tema e dos objetivos da pesquisa.

No decorrer da pesquisa marquei encontros com os sujeitos pesquisados para que fosse criado um vínculo que se transformasse em um canal de diálogo e gradativamente esse 
canal levasse ao desenvolvimento satisfatório da pesquisa. Segundo Triviños (2008, p.150), quando alcançado certo grau de "[...] simpatia recíproca, confiança mútua, entre informante e pesquisador, podemos dizer que os dados fornecidos são vitais para a pesquisa", porque o pesquisado demonstra interesse e participa ativamente no decorrer da investigação.

Também lancei mão da observação da dinâmica de formação nos momentos da coordenação coletiva, pois segundo Alves-Mazzotti e Gewandsznajder (2000), a observação constitui-se em um importante momento da pesquisa qualitativa, o qual valoriza o potencial humano, devido a sua condição de favorecer a compreensão da dinâmica da ação dos interlocutores em tempo real.

Além de considerar as relações humanas dentro do próprio contexto pesquisado, a observação favorece a construção de informações a respeito dos comportamentos não intencionais dos sujeitos, permitindo ainda a possibilidade de exploração de questões sobre as quais os participantes da pesquisa demonstrem algum tipo de dificuldade em se expressar, discutir, expor. Desse modo, houve a familiaridade com o contexto a ser pesquisado e aos poucos pude constituir certo grau de confiança mútua.

Foram doze encontros nas quartas-feiras, dias de coordenação coletiva. Com a seguinte dinâmica: Na UE 01 observando a coordenação pedagógica no período matutino e na UE 02 observando a formação no período vespertino e na semana seguinte invertendo os horários das observações. Nesse período houve um encontro inicial para a apresentação projeto de pesquisa e para a realização do convite aos futuros sujeitos da pesquisa. Os demais encontros foram de observação, entrevistas, respostas aos questionários e complemento de frases. Nem todas as quartas feiras contei com a presença dos professores na escola e em função da dinâmica da própria SEEDF, em algumas quartas não houve o momento coletivo da coordenação pedagógica.

Os momentos de observação da dinâmica pedagógica nos dias de coordenação coletiva me possibilitaram construir significados que foram compostos tanto pelo meu olhar de pesquisadora como pelo olhar dos interlocutores, oportunizando-me reconhecer momentos bastante significativos para a pesquisa.

No decorrer da pesquisa, surgiu a necessidade de eu também coletar dados e expressões dos gestores, afinal o espaço/tempo da coordenação pedagógica e a formação continuada docente que acontece naquele espaço é legitimada, fortalecida, impulsionada também pelo agir dos gestores. Então, com as duas diretoras eu utilizei questionários 
(Apêndice I) e a dinâmica conversacional individualizada que se constituiu em momentos de conversa após as observações dos momentos da coordenação pedagógica.

Segundo González Rey (2005), essa dinâmica permite que os interlocutores despertem para a corresponsabilidade das ações que são empreendidas no espaço pesquisado. Nessa dinâmica, pude depreender das falas das diretoras apontamentos expressivos a respeito das necessidades de formação do grupo e vê-las reconhecerem ao final, o quanto esses momentos de conversa sobre o objeto da pesquisa geraram boas reflexão em ambas.

Ainda segundo o citado autor,

As conversações caracterizam todo o processo de pesquisa e podem resultar do desdobramento de outros instrumentos aplicados. Portanto, os sistemas de conversação expressam qualidade da relação que define o espaço de pesquisa, relação que tem uma especial significação para o compromisso do sujeito com os diferentes instrumentos usados no processo. (GONZÁLEZ REY, 2005, p. 48).

E essa dinâmica foi justamente desenvolvida a partir das questões dos questionários aplicados para as diretoras, a partir de algumas dúvidas que foram surgindo no decorrer das minhas observações, mas principalmente quando o que eu via não era compatível com o que era expresso pelos professores regentes e pelas coordenadoras pedagógicas.

Também recorri aos documentos, tais como quadros e formulários criados pelas Coordenadoras Pedagógicas, pois segundo Yin (2010), todo documento é criado com alguma finalidade específica e para algum público específico. Logo, ao buscar identificar tais finalidades tive a possibilidade de interpretar mais objetivamente as concepções de formação continuada docente que se fazem presentes no espaço e no tempo da coordenação pedagógica em ambas as escolas.

A análise e a interpretação de dados não são "atividades simples, pois o trabalho analítico nos estudos de caso é altamente intuitivo" (GIL, 2009, p. 92). Assim, para que o leitor do trabalho confie nos resultados ali apresentados, a análise deverá ser bem detalhada mostrando que os dados fazem sentido.

Considerando essa complexidade e pensando em superá-la, todavia evitando a simplificação exacerbada ou a procrastinação na fase analítica como Yin (2010) alerta, segui uma estratégia analítica geral.

Destaco aqui três fases deste processo: a codificação dos dados; a apresentação de modo compreensível e adequado à pesquisa e uma análise aprofundada dos mesmos com base no contexto deste trabalho e no quadro teórico (BODGAN; BIKLEN, 1994). 
Ao analisar os questionários das professoras regentes, busquei compreender seu pensamento por meio do conteúdo expresso nos textos utilizando categorias temáticas a partir das quais busquei significações apreendidas a partir de categorias que realmente fossem relevantes à pesquisa. De acordo com Bardin (2011), a análise por categorias funciona com o desmembramento do texto em unidades reagrupando por afinidade analógica.

Os dados coletados foram organizados, tabulados e analisados, visando não perder de vista os objetivos propostos e buscando responder de maneira inteligível ao problema posto, afinal, "a busca da compreensão e da interpretação à luz da teoria aporta uma contribuição singular e contextualizada do pesquisador” (MINAYO, 2011, p. 27). Assim, os dados levantados e categorizados emergiram para a ampliação do debate do campo epistemológico da formação continuada dos professores da educação básica e das políticas públicas de formação docente ora vigentes no DF.

Considerando o referencial teórico e suas contribuições para as reflexões e críticas à formação continuada do docente no espaço/tempo da coordenação pedagógica das escolas públicas do DF, a importância social do tema e das possibilidades que surgem nesse percurso para desenvolver estudos mais aprofundados, estou convicta que a pesquisa contribuirá para a literatura educacional no âmbito da coordenação pedagógica, da formação continuada de professores, do planejamento do projeto político pedagógico e da organização do trabalho pedagógico nas instituições educacionais públicas do Distrito Federal.

Muitos desafios emergiram no caminho, mas cada um me levou a repensar a formação continuada dos professores da educação básica das escolas públicas do DF e a propor o rompimento com questões que impedem sua concretização em uma perspectiva emancipadora. 


\section{O TRABALHO COMO PRINCÍPIO EDUCATIVO}

O trabalho como princípio educativo vem sendo discutido por diversos autores contemporâneos como, Ciavatta, Franco, Frigotto, Kuenzer, Nosella, Mello (1982), Saviani (1988, 2002), entre outros. Ao afirmar sobre o caráter educativo do trabalho é necessário considerar a relação trabalho e educação, na qual se compreende o caráter formativo do trabalho como uma ação humanizadora que busca desenvolver todas as potencialidades do ser humano. Para tanto, fundamento esta pesquisa na perspectiva histórico-ontológica da formação humana da obra de Karl Marx.

Marx em um trecho do capítulo V do seu célebre livro, O Capital, afirma que “[...] antes de tudo, o trabalho é um processo entre o homem e a Natureza, um processo em que o homem, por sua própria ação, medeia, regula e controla seu metabolismo com a Natureza" (MARX, 1983, p. 149) e completa afirmando de forma inequívoca que nesse movimento de modificá-la, o homem também se modifica, se forma.

A partir da concepção marxista de que transformando a natureza, o homem transforma a si mesmo e a sociedade, pode-se afirmar que vindo de um longo caminho evolutivo, o homem, como ser social, tem o trabalho como atividade vital. Essa atividade assegura sua vida como espécie na qual “[...] incorpora, de forma historicamente universalizadora, a natureza ao campo dos fenômenos sociais" (SAVIANI, 2012, p. 21) de onde surgem tantas outras necessidades precipuamente sociais.

Esse salto, do homem orgânico ao homem social, não advém de heranças genéticas ou biológicas, ele se dá a partir do trabalho, da interação do homem com a natureza e de sua transformação concreta, o que vai possibilitar que a cada dia ele se afirme como homem, ser histórico e cultural, que alcance um maior nível de consciência sobre si e, consequentemente, produza novas situações formativas.

Essa produção social é fundada no trabalho, “[...] um tipo de atividade na qual o indivíduo humano primeiro elabora na consciência (como ideia, como ideação) para depois transformar a natureza naquilo que necessita" (LESSA, 2011, p. 142).

Nesse processo de transcendência das necessidades meramente orgânicas, 0 homem não apenas construiu materialmente a sociedade, mas também veio se formando como indivíduo e "[...] ele mesmo se defronta com a matéria natural como uma força natural. Ele põe em movimento as forças naturais pertencentes à sua corporalidade, braços e pernas, cabeça e mão, a fim de apropriar-se da matéria natural numa forma útil para sua própria vida" 
(MARX, 1983, p. 149-150). E nesse movimento, “[diferente do que ocorre no mundo animal] o que distingue, de antemão, o pior arquiteto da melhor abelha é que ele construiu o favo em sua cabeça, antes de construí-lo em cera" (MARX, 1983, p. 149-150).

Dessa forma, o homem, “[...] ao converter a natureza nos meios de produção e meios de subsistência, não apenas transforma a natureza, mas ao mesmo tempo, modifica sua própria natureza de ser social” (LESSA, 2011, p. 70), obtendo o resultado que desde o início do trabalho existia na sua imaginação.

Nessa perspectiva, compreendo que não há sociabilidade sem trabalho e nem sociedade sem história, pois a todo instante os homens ao influenciarem e ao receberem influência da sociedade, se formam e vão formando as novas gerações, pois o trabalho é "[...] um momento fundante da vida humana, ponto de partida no processo de humanização" (ANTUNES, 2010, p. 14).

Nessa relação indivíduo/objeto levando à generalização do conhecimento, este se torna patrimônio de toda a sociedade, fato de extrema importância para a humanidade, pois segundo Lessa e Tonet (2008), quanto mais genéricas as relações, maior a possibilidade de evolução social, sendo útil em inúmeras outras circunstâncias, isto é, essa dimensão social que promove modificações na história concreta é formação efetiva.

Saviani resume em poucas, mas inquestionáveis palavras o que seria o trabalho como princípio de formação do homem:

\footnotetext{
$\mathrm{Na}$ verdade, todo sistema educacional se estrutura a partir da questão do trabalho, pois o trabalho é a base da existência humana, e os homens se caracterizam como tais na medida em que produzem sua própria existência, a partir de suas necessidades. Trabalhar é agir sobre a natureza, agir sobre a realidade, transformando-a em função de objetivos, das necessidades humanas. A sociedade se estrutura em função da maneira pela qual se organiza o processo de trabalho (SAVIANI, 1988, p. 14).
}

Como é possível constatar, o trabalho é o princípio educativo, forma o homem e o torna capaz de levá-lo a atingir seus objetivos a partir da unificação de ideia, técnica e política, ou seja, de outorgar ao homem, à humanidade, sentido histórico e concretude ao que pode e ao que deve ser ensinado e aprendido, evitando abstrações desarticuladas aos temas e conteúdos necessários à formação humana.

A partir dessa noção ampla do trabalho como princípio vital para a formação do ser social, elejo-o também, como princípio pedagógico no processo de formação docente, pois 
transformando conscientemente a própria realidade, o professor também se (trans)forma, evolui.

Mas, além dessa questão mais filosófica/sociológica, é preciso considerar o trabalho na sociedade contemporânea, na qual a produção dos meios de existência se faz no sistema capitalista. Tal sistema se sustenta na lógica de se reproduzir pela apropriação do tempo de trabalho do trabalhador, que vende sua força de trabalho ao empregador que detém os meios de produção e remunera o trabalhador com salários que não contemplam o tempo de trabalho excedente ao valor contratado que é apropriado pelo dono do capital.

$\mathrm{Na}$ perspectiva marxista, o trabalho forma, entretanto, vivemos os ideais da burguesia em que o trabalho é embrutecedor e alienante. Assim, cabe questionar: de que maneira o trabalho pode se tornar educativo, humanizador, formar o ser humano?

Acredito que é a partir daí que se inicia a reflexão a respeito do trabalho do professor...

\subsection{Trabalho docente: Intelectual? Prático? Onde fica a práxis?}

No intuito não de responder ao questionamento anteriormente formulado, mas de iniciar reflexões a respeito da problemática em questão, trago aqui outros questionamentos relevantes, suscitados por Therrien (2012) a respeito das certezas e incertezas que permeiam o trabalho docente e que podem motivar novas buscas pela constituição da identidade do professor como agente de transformação do real.

Entenda-se bem, não pretendo aqui tratar da questão da perspectiva que embasa o trabalho do autor, mas dos questionamentos em si que ele traz e que podem nos levar a algumas reflexões importantes a respeito do trabalho docente.

[...] - Quem somos: Profissionais da educação? - Que trabalho é este: Mediadores de formação? - Para que atuamos? Produzir aprendizagem? - Que racionalidade rege nossa prática: A epistemologia da prática? - Que tempos configuram a aprendizagem? - O que sabemos de nossa competência: o que nos dizem as avaliações da educação? - Afinal, emancipação de quem? (THERRIEN, 2012, p. 110).

Diante de tais questionamentos considero importante lançar um olhar sobre o trabalho docente entendendo que a educação é tomada como um elemento fundamental para a consolidação das racionalidades instituídas no decorrer da história da humanidade e a para a 
consumação da seleção social, ou seja, para auxiliar o sistema a dizer quem fica no centro ou quem vai para as margens dele, ou dependendo do sistema, para agregar, unir, socializar.

Dessa forma, ela vai ter finalidades distintas de acordo com o tipo de dominação que é exercida em uma determinada sociedade e o seu funcionamento organizacional será fruto de um compromisso entre a estrutura formal em conexão com grupos que apresentam interesses distintos.

Considerando as reflexões expostas, compreendo que o trabalho docente poderá se colocar a serviço tanto da manutenção como da superação da ordem social vigente, pois como é possível perceber ele não se realiza apenas em um espaço físico, mas em um espaço/tempo político no qual se estabelecem poderes, hierarquias, negociações, compromissos etc.

Todavia, a despeito das relações dominantes, o princípio que fundamenta o trabalho docente é o processo de ensino e aprendizagem que se constitui como foco e deve ser concretizado. Não estou questionando aqui os meios de atingi-lo que também vão variar de acordo com a ideologia dominante, mas considerando ser o processo de ensino e aprendizagem, o grande objetivo do trabalho docente, pode-se afirmar que ele se corporifica pela prática profissional, ou seja, na docência em si.

Segundo Veiga (2012, p. 24), "no sentido etimológico, docência tem suas raízes no latim docere, que significa ensinar, instruir, mostrar, indicar, dar, atender”. Nesse sentido, caberá ao professor a responsabilidade de produzir situações que favoreçam a aprendizagem de conteúdos, mediando os processos de aprendizagem para a vida dos cidadãos, daqueles que futuramente se tornarão sujeitos na sociedade.

E aqui, vale retornar a Therrien (2012) quando este autor comenta a respeito da racionalidade que rege o trabalho do professor, afinal, todo trabalho é regido por um tipo de racionalidade e será essa a força motriz para se buscar ou não, a transcendência dos valores instituídos pela lógica do capital.

Saviani, a partir de um breve histórico da educação no Brasil, afirma que no final da década de 1970 , diante das evidências do caráter reprodutivista ${ }^{1}$ da pedagogia oficial, os professores começaram a se questionar:

Esta pedagogia oficial que se tentou generalizar é inconsciente, é passível de contestação, atende a interesses minoritários, atende à tentativa dos grupos dominantes de impor a toda a sociedade a sua dominação. Mas, e então? Se essa educação, essa forma de ensinar, não é adequada, qual será? Havia, pois, uma

\footnotetext{
${ }^{1}$ Reprodutivista: que tem a função de reproduzir as relações sociais vigentes (SAVIANI, 2012, p. 78).
} 
expectativa muito grande entre os professores no intuito de se responder à questão: como devo me conduzir no processo educativo? (SAVIANI, 2012, p. 78).

É interessante perceber a postura crítica do professor diante do que está posto. Acredito que indagações como as propostas por Saviani (2012) muito contribuirão para trazer à luz um olhar diferenciado do professor a respeito do seu trabalho. Esse posicionamento político será fundante para que o trabalho docente confira à educação o poder que lhe é devido, o poder de emancipar os indivíduos.

Considerando as reflexões feitas até aqui, vejo a importância não só da "competência técnica", mas igualmente da "competência política" (SAVIANI, 2012, p. 27), pois, para a concretização do objetivo do trabalho docente que é ensinar, na perspectiva emancipatória, o professor deverá ter conhecimento das especificidades da docência tendo uma visão articulada dos aspectos relevantes à sua própria prática com as questões sociais. Esta, como meio de realizar o compromisso ético que aponte para o cumprimento das vitais e históricas funções de mudança da sociedade, extinguindo com a exploração do homem pelo homem.

Diante da utilização dos termos "competência técnica" e "compromisso político" (SAVIANI, 2012), considero oportuno esclarecer que ao me referir à competência ${ }^{2}$, não estou fazendo alusão ao professor competente no sentido tecnicista, que começa a surgir na literatura sociológica no Brasil a partir dos anos de 1990 e que traz o conceito de competência em termos da qualificação dos trabalhadores nos moldes do "saber, saber-fazer e saber-ser", tornando-os pilares da educação para o século XXI (DELORS, 1999). Mas, sob a visão de Mello, ao afirmar que a competência

[...] inclui o saber técnico, começa muito aquém deste e o ultrapassa. Mas não o exclui, isso é importante; ao contrário, subentende-o como mediador da sua própria superação. [...] começa no domínio dos próprios conteúdos que tradicionalmente constituem o currículo, ou seja, numa reapropriação satisfatória do saber escolar. Inclui o domínio das técnicas e métodos de ensino que permitam a transformação desse saber, passa pela aquisição de uma visão mais integrada da própria prática e uma reapropriação dos processos do trabalho docente (método, planejamento, avaliação). E projeta-se a partir dessa base, numa visão mais crítica desse ensino, dessa escola e de seu conteúdo, a qual não se dissocia de um questionamento de suas condições de trabalho e remuneração, e de uma prática coletiva de organização e reivindicação (MELLO, 1982, p. 55-6, grifos do original).

E completa indicando a perspectiva do termo político como sendo aquele que "se realiza pela mediação da competência técnica e constitui condição necessária, embora não

${ }^{2}$ Grifo nosso. 
suficiente, para a realização desse mesmo sentido político da prática docente para o professor" (MELLO, 1982, p. 44).

É óbvio que educacionalmente há de se considerar a influência das mudanças políticas, sociais e econômicas que vem acontecendo no cenário mundial, inclusive na busca em se consolidar a noção de competência advinda do padrão toyotista de produção com a fragmentação e precarização do trabalho visando atender os imperativos do mercado (JIMENEZ; MAIA, 2013, p. 122).

E, ainda, segundo Jimenez e Maia, os quatro pilares da educação popularizaram um novo paradigma educacional fundamentado no que eles denominam de CHAVE (C de conhecimento, $\mathrm{H}$ de habilidade, $\mathrm{A}$ de atitude, $\mathrm{V}$ de valores e $\mathrm{E}$ de existencial), evidenciando nos nossos dias a hipervalorização do cognitivo e do prático como o ensino baseado em conteúdos e habilidades que se ligam a determinada qualificação para o mercado, "em detrimento de outras dimensões fundamentais do ser humano" (JIMENEZ; MAIA, 2013, p. 113-114).

Esse modelo de competências, em tese, levaria à superação de problemas educacionais,

[...] em primeiro lugar, por sintonizar-se com as importantes mudanças econômicas, políticas e sociais ocorridas no mundo; em segundo lugar, por integrar as quatro dimensões centrais do processo de aprendizagem humana e, assim, superar os problemas postos pelos paradigmas que focavam o processo em uma, ou no máximo, em duas esferas (e, mais grave, não conectadas) do saber. (JIMENEZ; MAIA, 2013, p. 115).

Todavia, seria pueril crer que apenas um projeto educacional, mesmo que de proporções mundiais, seria suficiente para resolver os problemas oriundos do próprio sistema que o concebeu. Ademais, vale ressaltar que sendo financiado pelo Banco Mundial, não há como negar que tal projeto seja visto apenas, como mais uma tentativa de superação da crise estrutural do capital.

O Banco Mundial passou a investir maciçamente na esfera educacional com a finalidade de produzir as ideologias necessárias para que os trabalhadores sejam paulatinamente conformados às "perversas condições infligidas por esse mercado" (JIMENEZ; MAIA, 2013, p. 121) e, convencidos por seus discursos, acolham-nas automaticamente, ou seja, sem reflexão, sem crítica, sem contestação. Entretanto, na verdade, tais discursos são inerentes aos objetivos do projeto educacional tendo por missão conservar o modo de produção capitalista. 
Acolhendo a competência técnica como pretexto para o desenvolvimento das transformações que o próprio sistema diz serem necessárias para a constituição de uma sociedade melhor e de oportunidades igualitárias, os professores a cada dia que passa vão sendo formados para a reprodução do cotidiano alienado determinado pela lógica do capital.

Tendo clareza dos intentos da formação do professor competente, é interessante perceber a necessidade de se fortalecer o movimento do trabalho docente tendo como núcleo a sistematização e a fundamentação na "filosofia da práxis"3 (SAVIANI, 2012, p. 47), em que o professor, a partir do seu trabalho, na docência, cerne de sua profissão, começa a se enxergar como sujeito que observa, que estuda a sua realidade, que se posiciona criticamente e que dessa forma, tem possibilidades reais de alavancar transformações na realidade social, sua e de seus alunos.

No intuito de enriquecer a compreensão da necessidade tanto da teoria como da prática no trabalho docente, me reporto a Vázquez, ao afirmar que

[...] a teoria em si [...] não transforma o mundo. Pode contribuir para a sua transformação, mas para isso tem que sair de si mesma, e, em primeiro lugar, tem que ser assimilada pelos que vão ocasionar, com seus atos reais, efetivos, tal transformação. Entre a teoria e a atividade prática transformadora se insere um trabalho de educação das consciências, de organização dos meios materiais e planos concretos de ação: tudo isso como passagem indispensável para desenvolver ações reais, efetivas. Nesse sentido, uma teoria é prática na medida em que materializada, através de uma série de mediações, o que antes só existia idealmente, como conhecimento da realidade, ou antecipação de sua transformação (VÁZQUEZ, 1977, p. 206-207).

De fato, o trabalho docente se constitui no nível intelectual, no sentido de ter o momento para estudar e refletir acerca de teorias e ideias, de modo que seu intelecto possa criar novas situações que tenham uma relevância social e coletiva; como no nível prático, o agir, o fazer em si.

Por isso, é tão importante que o professor busque reorganizá-lo a partir da "superação da dicotomia entre trabalho manual e trabalho intelectual, entre pensar e fazer, entre teoria e prática" (LOMBARDI; SAVIANI, 2008, p. 27), em que a atividade prática se submete, se conforma à teoria e a teoria se modifica em função das necessidades e exigências do próprio real constituindo a práxis.

\footnotetext{
${ }^{3}$ No sentido marxista, práxis diz respeito à atividade livre, universal, criativa e autocriativa, por meio da qual o homem cria (faz, produz) e transforma (conforma) seu mundo humano e histórico, a si mesmo (Dicionário Marxista).
} 


\subsection{O sentido da escola e o trabalho pedagógico}

Historicamente, a escola, desde que foi instituída, “[...] alterna modelos ideais, métodos e metodologias pedagógicas, incorporando influências e mudanças" (FURTADO, 2012, p. 215). Considerando essa premissa, pergunto: O que será que o professor pensa a respeito do papel da escola para a sociedade? Será que o trabalho pedagógico desenvolvido na escola expressa claramente seu pensamento sobre esse papel social da escola?

Até aqui, parece clara a estreita ligação entre a educação e a história humana, história materializada pelo trabalho do homem que vem se formando e ao se formar, forma a história da humanidade. No entanto, diante de um novo paradigma produtivo expresso em novas formas de produção baseadas nas novas tecnologias e na chamada globalização, o modelo educacional, de acordo com o modelo econômico, tem sido usado para atender a lógica da subordinação da sociedade às leis do mercado, sempre visando o lucro e lançando mão da eficiência, da produtividade e da competitividade.

Diante desse panorama, tem-se então uma escola "[...] comprometida com o desenvolvimento de habilidades e competências exigidas pelo mundo moderno" (COÊLHO, 2012, p. 15), se debatendo na incompreensão de inúmeras questões sociais que a envolve e vivendo incontáveis mudanças estabelecidas pelo sistema. Essas mudanças, em termos práticos, vêm impactando na imagem social da escola e o trabalho pedagógico que nela é organizado e a organiza.

O trabalho pedagógico aqui defendido é aquele que é efetivamente realizado na escola, oferecendo suporte ao professor, auxiliando na estruturação do Projeto Político Pedagógico, refletindo sobre a gestão, desenvolvendo a formação docente e que tomando por base um referencial teórico, discute acerca das questões demandadas pelo grupo em voga socialmente (SILVA; DE SORDI, 2006).

Na contemporaneidade, a partir do paradigma burguês, busca-se ampliar o acesso, diminuir a idade de ingresso e o tempo de permanência ${ }^{4}$ dos alunos na escola, alteram-se os conteúdos a serem trabalhados e institui-se um discurso romântico de que é por meio da educação que se atinge os níveis mais altos de cidadania, o que significa participação ativa das classes menos favorecidas no processo de construção social.

Esse discurso da cidadania apresentado e difundido pela ótica neoliberal implica em afirmar que a partir da existência de classes sociais antagônicas, cabe ao Estado apenas,

\footnotetext{
${ }^{4}$ Esse fenômeno é denominado por Saviani de "hipertrofia da escola" (2012, p. 84). Na sociedade moderna
} ocidental, a forma dominante de educação é a escolar, qualquer outra forma de educação é vista negativamente. 
“[...] o papel de mediador para que as desigualdades sociais não se ampliem de tal modo a ferir o direito de todos ao acesso a um mínimo razoável de riqueza social” (TONET, 2005b, p. $81)$.

A meu ver, ser cidadão não é ser efetivamente livre, mas apenas formalmente. Por mais direitos que o cidadão tenha e por mais que estes direitos sejam aperfeiçoados, a desigualdade jamais será eliminada, pois no interior da ordem social burguesa há uma barreira intransponível. Consequentemente, esse discurso cidadão pode atender temporariamente a necessidade popular, mas jamais será uma forma de sociabilidade na qual os homens sejam efetivamente livres.

A emancipação, como abordado em outro momento, supõe a erradicação do capital e de todas as suas categorias. Sem o seu fim se torna impossível a constituição de uma autêntica comunidade humana. E esta erradicação não significa, de modo algum, o aperfeiçoamento da cidadania, mas, ao contrário, a sua mais completa superação.

Grosso modo, pode-se concluir que no âmbito desse discurso vem justamente a intenção de reforçar a ideia de conformação com as desigualdades sociais, visto que elas não são suprimíveis, apenas minimizáveis. É nesse modelo social, no qual o homem aceita a degradação do próprio homem, que a escola vem sendo conformada, aceitando e perpetuando regras incontestáveis sobre a natureza e a naturalidade da exploração do homem pelo próprio homem.

Entretanto, a escola tem, ou pelo menos deveria ter a função educativa ligada às questões do conhecimento, do saber, não se tratando, pois,

[...] de qualquer tipo de saber. Portanto, a escola diz respeito ao conhecimento elaborado e não ao conhecimento espontâneo; ao saber sistematizado e não ao saber fragmentado; à cultura erudita e não à cultura popular. Em suma, a escola tem a ver com o problema da ciência. Com efeito, ciência é exatamente o saber metódico, sistematizado (SAVIANI, 2012, p. 14).

Eis aí a contradição discutida por Saviani (2012). Desse modo, faz-se necessário resgatar essa razão de ser da escola que é de sistematizar o conhecimento e transmiti-lo a todos de forma não discriminatória (SAVIANI, 2012), transcendendo a imagem deturpada de que ela tem que atender às demandas do Estado e, por consequência, às demandas do mercado.

Como é possível observar, a escola, com base na organização do trabalho pedagógico pode colocar o saber a serviço da manutenção ou da transformação das relações sociais, servindo para alienar ou emancipar o homem. 
Essa contradição do papel da escola hoje tem origem na própria natureza do trabalho na sociedade capitalista e nos leva a compreender o campo de luta hegemônica no qual está inserida. Portanto, não é possível ignorar o modelo social organizacional vigente e a dinâmica das relações de poder que estabelecem o seu controle social.

Enquanto for banalizada “[...] a leitura, a escrita, o estudo, o pensamento, a crítica e a criação", esquecendo e silenciando a "[...] natureza e a temporalidade própria do humano, da cultura e da educação, bem como a dimensão educativa da escola e dos processos formativos" (SAVIANI; DUARTE, 2012, p. 15) que ela possibilita, esse espaço de socialização e democratização do saber de nada servirá para formar a ideologia contrahegemônica.

Em larga medida, a escola tem sido vista, definida e aceita como um lugar de assistência social destinado à minimizar as mazelas intrínsecas ao capitalismo e o trabalho docente do mesmo modo, sendo reduzida a cuidar de questões tais como, direitos humanos, educação em gênero e sexualidade, educação das relações étnico-raciais, diversidade, sustentabilidade e cidadania ${ }^{5}$, não que tais temas não sejam relevantes para a formação do ser humano, mas a educação não pode se restringir apenas a isso.

A escola deve estar voltada ao ensinar, buscando a concretização do processo de ensino e de aprendizagem, equilibrado entre teoria e prática de modo a favorecer a formação de sujeitos críticos e emancipados. De igual modo, o trabalho pedagógico deve ser organizado para superar o processo de proletarização da profissão docente facilitando o acesso e a participação do professor na organização da gestão, tanto no âmbito pedagógico como no âmbito administrativo, colocando-o em condição de ver as contradições do mundo moderno e questioná-las buscando a superação.

Apesar de ser nítido o esvaziamento da função da escola, compreendo a organização do trabalho pedagógico como fundamental para o desenvolvimento de uma cultura que contribui para a formação do homem enquanto homem. Para tanto, o professor deverá tomar consciência de sua profissionalidade, de sua responsabilidade ética e de modo intencional e sistematizado, vir a produzir novos conhecimentos para serem compartilhados com seus alunos e com seus pares.

Entendo, então, que a ausência da organização do trabalho pedagógico para nortear o fazer docente ou a provisoriedade das ações pautadas em atender demandas imediatistas do dia-a-dia escolar, pode vir a ser um tanto quanto problemática para o

${ }^{5}$ Eixos estruturantes do Currículo em Movimento, SEEDF-2012. 
rompimento de determinados paradigmas que fortalecem hegemonias do campo econômico, ora transferidas para o campo educacional.

A partir da lógica que rege a sociedade, tenho a convicção de que a escola jamais resolverá os problemas gerados pelo modelo econômico atual, pois estes são inerentes ao próprio capital, mas acredito que ela possa se constituir como forte colaboradora para a emancipação humana transmitindo o vasto patrimônio histórico produzido pela humanidade.

Talvez, essa consciência não seja construída apenas a partir de reflexões individuais pontuais, nem da prática cotidiana e espontânea do professor. Talvez ela deva ser mediatizada pela formação continuada docente articulando subjetividade e objetividade. 


\section{FORMAÇÃO CONTINUADA DOCENTE: UM CONTEXTO DE CONTRADIÇÕES}

Há décadas que se discute a formação docente no Brasil e se levantam questões e apontamentos reflexivos a respeito desta temática que vem impactando no contexto educacional. No entanto, apesar da temática interessar aos órgãos governamentais e não governamentais, intelectuais e instituições educacionais, a formação continuada docente ainda transita em um território ideológico contraditório (ZEICHNER, 1998).

Com objetivo de fortalecer meu percurso reflexivo, trago agora, duas questões levantadas por Veiga e Quixadá Viana (2012, p. 13): “A formação está voltada para qual contexto social? A formação de professores está voltada para qual escola básica?”.

Segundo as citadas autoras, "no sentido etimológico, a palavra "formação" vem do latim formare, que, como verbo transitivo, significa dar forma; como verbo intransitivo, significa colocar-se em formação e, como verbo pronominal, significa ir-se desenvolvendo uma pessoa" (VEIGA; QUIXADÁ VIANA, 2012, p. 20).

Considerando tal definição, compreendo que a formação terá um começo, mas nunca um fim. Logo, a formação continuada docente realizada no espaço escolar, entre outros aspectos, deverá considerar o professor como um ser em formação, que a partir da reflexão de suas experiências profissionais individuais ampliará seu foco de atuação incorporando boas práticas e contribuindo para a transformação dos sujeitos que com ele transitam naquele espaço. Como é possível observar, a formação implica ação e interação. Quando se pensa no que vem a ser formar ${ }^{1}$, encontra-se uma infinidade de termos que hoje fazem parte do vocabulário da formação docente de onde nascem várias interpretações e defesas ideológicas. Cabe aqui ressaltar que para muitos, formar significa profissionalizar ou dotar de competência ${ }^{2}$, mas para mim, apoiada em Veiga e Quixadá Viana (2012), formar é o meio de desenvolvimento profissional contínuo e singular que leva o professorado a estabelecer uma nova relação com o conhecimento e com a sua prática.

\footnotetext{
${ }^{1}$ Grifo meu.

${ }^{2}$ Termos e expressões encontrados no Livro Iluminismo às avessas (MORAES, 2003).
} 
No entanto, mesmo diante de tantos termos e interpretações do termo formar, o que é mais preocupante é quando ele é utilizado com o significado (con)formar. Pois daí, o professor ao se conformar ao sistema, passa a transmitir o que é produzido pela classe dominante e sucumbe à sua lógica perdendo a capacidade de se apropriar criticamente de pontos essenciais para a sua emancipação.

Fazendo uma breve leitura dos Referenciais para a formação de professores do MEC, é interessante refletir a respeito da formação docente, a partir deste documento oficial. A formação preconizada pelo Estado nos Referenciais traz questões importantes do panorama educacional brasileiro tais como, a necessidade da formação docente possibilitar práticas inovadoras e pesquisa e recomposição salarial (BRASIL, 1999, p.28-29).

Entretanto, ao continuar a leitura, percebe-se que seu discurso utiliza termos que são utilizados mais como slogan (SANTOMÉ, 1998), estão ali postos porque o povo quer ouvir $^{1}$, trazendo em si, ora de maneira explícita ora de maneira velada, a ideologia burguesa e não uma proposta de superar a contradições existentes.

Há no mesmo documento proposições como:

É preciso que todos aprendam a valorizar o conhecimento e os bens culturais e a ter acesso a eles autonomamente, [...] E que aprendam a ler criticamente diferentes tipos de texto, utilizar diferentes recursos tecnológicos, expressar-se em várias linguagens, opinar, enfrentar desafios, criar, agir de forma autônoma. (BRASIL, 1999, p. 24).

Mas, ao mesmo tempo o documento traz restrições baseando o conhecimento e o convívio social nos pilares: "aprender a conhecer, aprender a fazer, aprender a viver junto e aprender a ser" (BRASIL, 1999, p. 26). Alega que essa perspectiva traz nova concepção de educação e por isso a formação docente deve ser redimensionada para o exercício profissional $^{2}$ que seja capaz de realizar um trabalho educativo que garanta o desenvolvimento de "[...] capacidades imprescindíveis para que crianças e jovens não só conquistem sucesso escolar, mas, principalmente, capacidade pessoal que lhes permita plena participação social num mundo cada vez mais exigente sob todos os aspectos" (BRASIL, 1999, p. 26).

Fica claro no discurso que a formação docente está voltada para o exercício profissional, isto é, corresponder às exigências do mercado. E a autonomia, como slogan, tem por objetivo tornar tanto professor como aluno, responsáveis por sua própria formação,

${ }^{1}$ Grifo meu.

${ }^{2}$ Grifo meu. 
tirando a responsabilidade do Estado e que essa formação atenda às necessidades de um mundo a cada dia mais exigente, ou seja, um mercado sedento por pessoas especializadas.

Contudo, o que mais me chamou a atenção foi o jogo velado de culpa/desculpa quando o documento se referiu à ligação da desqualificação ${ }^{3}$ profissional com a deterioração dos salários, à feminilização da profissão como símbolo de desvalorização social, ao baixo nível sócio econômico dos professores como sendo um dos motivos deles terem uma formação geral insuficiente e ao fato de o professor estar sempre desatualizado por escrever e ler pouco.

Outro ponto intrigante é o fato de que em nenhum momento se ver referência ao que sustenta teoricamente as falas, a não ser o apoio no senso comum, como é possível aferir nos trechos transcritos, “[...] a feminilização da função [...] tem se convertido num símbolo de desvalorização social. O imaginário social foi cristalizando uma representação de trabalho docente destinado a crianças [...]” (BRASIL, 1999, p. 31), “[...] a partir da observação, de depoimentos pessoais e de estudos que começam a surgir" (BRASIL, 1999, p. 32) - Que estudos? Torna-se explícita a precariedade dos alicerces no qual o documento se embasa.

É um tanto intrigante o fato de o citado documento declarar que o perfil do professor apesar de não ser "o" problema da baixa qualidade da educação é um dos responsáveis pela baixa qualidade do ensino e dos níveis de fracasso escolar e, mais uma vez, sem qualquer embasamento efetivo, conforme aponta o trecho que segue:

\footnotetext{
Conforme vão se evidenciando os níveis inaceitáveis de fracasso escolar dos alunos, intensifica-se a crítica aos professores como responsáveis pela ineficiência do sistema educacional. Entretanto, apontá-los como principais - e às vezes únicos responsáveis pelos índices de insucesso escolar é revelar a incapacidade para uma análise séria e global da questão. O professor não pode ser visto como "o" problema, mas como imprescindível para a superação de parte dos problemas educativos. (BRASIL, 1999, p. 33).
}

Afirmo ser intrigante pelo fato de os professores, os quais o documento se refere, serem formados a partir da legislação e de políticas públicas efetivadas pelo próprio Estado. Logo, a precariedade dessa formação tem a sua responsabilidade pelo insucesso do sistema educacional e não só o professor. Sem dúvida que o reconhecimento pelos próprios professores do seu papel de agente social, é fator importante para a superação dos problemas educacionais vivenciados. 
No entanto, mais uma vez me reporto à formação docente, tanto inicial quanto continuada, como fatores preponderantes para esse reconhecimento e sem dúvida, não poderia deixar de destacar a formação não nos moldes do sistema atual estrategicamente idealizada para alimentar o mercado, mas em uma perspectiva emancipatória, estruturada a partir da realidade, das necessidades da comunidade escolar.

Excede os limites desse trabalho o aprofundamento da discussão sobre esse ponto, mas com ele, é possível compreender um dos porquês da precariedade da formação docente na atual realidade brasileira que, lamentavelmente não tem se dado na perspectiva de superação do modelo econômico atual, ao contrário, tem formado o professor “[...] a dominar um conjunto de competências que de acordo com as demandas da sociedade do conhecimento sejam processuais e se cultivem ao longo da vida" (MORAES; TORRIGLIA, 2003, p. 50).

Está claro que a formação oferecida pelo Estado, em geral, não é pensada a partir das necessidades reais do contexto educacional. Mais uma vez, ela surge das demandas ideológicas da classe hegemônica. Compreendo que ela assume enfaticamente esse ideal de qualificar força de trabalho para a manutenção e a garantia da acumulação do capital nas mãos de poucos, principalmente por não ser idealizada e estruturada partindo dos processos de reflexão e de crítica da realidade vivida pelos professores da escola.

Diante desse contexto contraditório, retomo as questões levantadas por Veiga e Quixadá Viana (2012) a partir das quais, compreendo que a formação continuada docente no local de trabalho pode sim, vir a ter o preponderante papel de despertar os professores para a necessidade de romper com a formação precarizada, instituída unilateralmente pelo governo.

Todavia, quero crer que nem tudo está perdido, pois a formação na perspectiva do capital também pode ser a detonadora da necessidade transgressora de romper com sua lógica e se tornar meio de desenvolvimento profissional contínuo e singular levando os professores a estabelecerem uma nova relação com o conhecimento e com a sua prática, reelaborando a práxis social (RABELO; RIBEIRO, 2003, p. 227).

Para tanto, a formação docente deve ganhar materialidade não se restringindo a refletir apenas sobre as ações do professor em sala de aula buscando o aprimoramento da prática, mas favorecendo a "[...] apropriação crítica das essenciais determinações do real", por meio do aprofundamento epistemológico (PLACCO; SILVA, 2011). Dessa forma, ela será motivadora do professor, provocando-o a atuar de forma surpreendente, criativa e dialética com o novo na constituição da práxis. 
Ela deverá também, possibilitar a reflexão dos professores a respeito dos aspectos que possibilitam a produção de conhecimento capaz de gerar transformações dos valores estabelecidos socialmente e que não condizem com sua formação de ser social e cognoscente, de forma que venha a contribuir para a formação de novas concepções que fundamentem o seu ato de ensinar em uma perspectiva emancipatória.

A formação docente que preconizo, é compreendida em seu aspecto fundamental para a concretização de uma educação cada vez mais preocupada com o político, histórico e social, ou seja, na perspectiva da omnilateralidade "[...] devendo atingir uma gama muito variada de aspectos da formação do ser social, portanto, com expressões nos campos da moral, da ética, do fazer prático, da criação intelectual, artística, da afetividade, da sensibilidade, da emoção etc" (SOUZA JUNIOR, 1999, p. 101), representando uma formação ampla e avançada.

Deverá buscar, ainda, romper com a perspectiva do homem limitado da sociedade capitalista, proporcionar aos docentes o desenvolvimento de habilidades críticas e de investigação da própria realidade. E, fundamentada no currículo vigente ter como objetivo desenvolver o fazer pedagógico buscando atender às necessidades educacionais e sociais dos envolvidos no processo educativo, levando-os à condição de sujeitos de suas histórias. Contudo,

[...] essa ruptura não implica [...] a compreensão de uma formação de indivíduos geniais, mas, antes, de homens que se afirmam historicamente, que se reconhecem mutuamente em sua liberdade e submetem as relações sociais a um controle coletivo, que superam a separação entre trabalho manual e intelectual e, especialmente, superam a mesquinhez, o individualismo e os preconceitos da vida social burguesa (SOUZA JUNIOR, 1999, p. 102).

Creio que a formação continuada deve despertar o professor a compreender que "[...] a nossa tarefa educacional é simultaneamente, a tarefa de uma transformação social, ampla e emancipadora" (MESZÁROS, 2012, p. 76) e que esta pressupõe o agir pedagógico/crítico/dialógico de produzir conhecimentos para uma educação que ultrapassará os muros das escolas, uma educação para a vida.

\subsection{A Formação continuada como possibilidade de emancipação docente}

“É possível a emancipação humana?” (TONET, 2005a, p. 149). É assim que este autor inicia o capítulo que fala a respeito da emancipação da humanidade no seu livro Educação, cidadania e emancipação humana. Ele continua com as seguintes indagações: 
"Pode o homem transformar radicalmente a realidade social? [...] Quais as condições gerais de possibilidade - histórico-estruturais - necessárias para que esse objetivo seja alcançado? Quais as mediações (condições específicas, ações concretas, estratégias, táticas etc.) para realizá-las?" (TONET, 2005a, p. 149).

Partindo desses questionamentos e dos desdobramentos que deles decorrem, busquei fundamentar o meu pensamento a respeito da imprescindível e indissociável ligação entre a formação docente e a emancipação do professor.

Emancipação é um termo muito utilizado, não só por marxistas, mas também encontrado nos documentos oficiais ${ }^{4}$. Mas de qual emancipação se fala? No dicionário Houaiss de língua portuguesa, emancipação é, “tornar-se independente, libertar-se" (TONET, 2005b, p. 268). Sim, e qual é o sentido de liberdade para nós? Que emancipação defendo? Sustentada a partir de que fundamento teórico?

O meu ponto de partida então é o fundamento do ser social, isto é, o trabalho. O trabalho é o ato originário do ser social, mas não significa que ele se esgota na natureza deste ser, ao contrário, por sua própria natureza, ele se caracteriza por se constituir em uma atividade que tem a possibilidade produtiva cada vez mais ampla. Segundo Tonet (2005a, p. 132), “[...] ele é a mediação que permite o salto ontológico da natureza para o homem, como também continuará a ser este fundamento na medida em que é condição natural eterna da vida humana, independente da forma como ela se realize".

Essa afirmação de Tonet é fundamental para a compreensão da formação continuada como possibilidade de emancipar o professor, justamente por esse caráter natural e eterno de formação que o homem traz em si. O professor é um ser social, é um ser radicalmente histórico e social, isso significa dizer que não existe algo nele que não possa mudar e que a sua totalidade é sempre o resultado dos atos humanos. Logo, as relações que são estabelecidas entre os professores como características do trabalho docente e suas condições reais de atuação no espaço escolar possibilitam que eles, em especial nos momentos formativos, tomem consciência da realidade objetiva, concebam antecipadamente o fim que pretendem alcançar e atuem sobre a sua realidade a fim de transformá-la de acordo com os objetivos previamente estabelecidos no coletivo.

Mas será que isso seria suficiente para favorecer a emancipação docente?

Acredito que não. Principalmente pelo fato de a escola, instituição social que em diferentes níveis está atrelada ao sistema dominante, pensar e fundamentar a formação

\footnotetext{
${ }^{4}$ Referenciais de Formação do Professor e Currículo em Movimento.
} 
continuada docente de forma prática, ou seja, “[...] tendo como finalidade a instrução de homens capazes de atender às necessidades práticas imediatas postas na ordem do dia" (GUIMARÃES, 2012, p. 131).

Contraditoriamente, ao invés de formar para emancipar, a formação tem servido para conformar, para atender às exigências da sociedade constituída. A formação está a serviço da luta pelo alcance da liberdade para a busca da satisfação individual desprezando as ações que visam o bem comum.

Nessa perspectiva, a formação tem servido para levar os homens a aceitarem a realidade como algo imutável e sua tarefa sendo apenas a de se ajustar, se adequar, estar em conformidade com os valores estabelecidos socialmente pela classe dominante.

No meu entendimento, para que a formação docente seja concretizada como possibilidade emancipatória, ela deve ter como pressuposto fundamental, o conhecimento "[...] da natureza do fim que se pretende atingir, no caso, a - própria - emancipação humana" (TONET, 2005a, p. 226), cabendo aos formadores a estruturação do projeto de formação não baseado em ideias vagas, mas fundamentado no compromisso com a teoria, com o conhecimento sistematizado distinguindo o tradicional do clássico 5 .

Minha defesa é da formação que contribua para a efetiva libertação dos indivíduos conscientizando-os da sua condição de sujeitos solidários - sujeitos porque tem nas próprias mãos a real possibilidade de compreenderem e transformarem a própria história e solidários porque de fato constroem sua história com o outro, sem querer subjugá-lo.

Formação que preconize o "[...] homem omnilateral, aquele que se define não propriamente pela riqueza do que o preenche, mas pela riqueza do que lhe falta e se torna absolutamente indispensável e imprescindível para o seu ser: a realidade exterior, natural e social criada pelo trabalho humano como manifestação humana livre" (SOUZA JUNIOR, 1999, p. 100). Nessa minha defesa encerra-se o posicionamento oposto à formação na atual ordem social.

Segundo Tonet, uma formação emancipatória deve pautar-se na consciência da necessidade de uma educação eficaz e para isso ela tem que oferecer

[...] uma compreensão, a mais ampla e profunda possível, da situação do mundo atual; da lógica que preside fundamentalmente a sociabilidade regida pelo capital; das características essenciais da crise por que passa esta forma de sociabilidade; das consequências que daí advêm para o processo de autoconstrução humana; da

\footnotetext{
${ }^{5}$ Saviani nos alerta a respeito da necessidade dessa diferenciação em que tradicional seria o ultrapassado e clássico como o que resistiu ao tempo, o incontestável (SAVIANI, 2012, p. 87).
} 
maneira como esta crise se manifesta nos diversos campos da atividade humana: na economia, na política, na ideologia, na cultura, na educação; e também da forma como esta crise se apresenta na realidade nacional e local. (TONET, 2005a, p. 232).

Embora seja grande a distância do ponto em que estamos ao ponto que desejamos chegar, é gratificante pensar que a caminhada já começou. Afinal, acredito que a formação continuada docente, atividade com uma especificidade própria de transformar situações, pode contribuir para transformar mentes que transformarão a humanidade.

Sem dúvida, o professor tem uma árdua tarefa pela frente, principalmente considerando que não terá apenas que se apropriar do saber, mas se posicionar criticamente diante dele, apesar de estar vivendo em um contexto que o impele a contrariar tudo isso.

É nesse contexto de contradições que a necessidade de se pensar e repensar o espaço/tempo da coordenação pedagógica, as atribuições e as ações do coordenador pedagógico nesse espaço, emerge, de forma incontestável, e é a essa visão da história, do espaço, das atribuições e das superações que tratarei a seguir.

\subsection{A formação continuada por dentro da escola}

Contemporaneamente, o que tenho visto e vivido no meu contexto profissional é uma formação continuada de cima para baixo, padronizada, implementada por especialistas na qual se desconsidera o conhecimento que o professor amealhou na sua trajetória (IMBERNÓN, 2010).

O "ser professor", como afirma Nóvoa, implica

[...] compreender os sentidos da instituição escolar, integrar-se numa profissão, aprender com os colegas mais experientes. É na escola e no diálogo com os outros professores que se aprende a profissão. O registro das práticas, a reflexão sobre o trabalho e o exercício da avaliação são elementos centrais para o aperfeiçoamento e a inovação. São estas rotinas que fazem avançar a profissão. (NÓVOA, 2011, p. 49).

Logo, a formação continuada docente deve assumir a práxis embasada no contexto escolar voltada para a aprendizagem dos alunos tendo como referências as situações reais que nascem cotidianamente na escola. Mesmo sabendo que caminho na contramão da formação que hoje vigora na rede pública de ensino do Distrito Federal, eu acredito e preconizo a inversão dessa formação que vem tradicionalmente sendo imposta pela lógica dominante, trazendo o planejamento, a reflexão e a crítica do fazer pedagógico para dentro da escola, partindo das situações que dela emergem. 
No meu entendimento, a formação continuada deve estar a serviço da aprendizagem, ou seja, deve trazer em si, o objetivo de levar o professor a reconhecer as singularidades dos alunos e a partir daí elaborar estratégias de ação que favoreçam a aprendizagem do aluno.

Desse modo, a formação que vem de fora da escola dificilmente atenderá as reais necessidades que surgem do contexto escolar com suas especificidades, ao contrário, poderá apenas se configurar como uma formação transmissora, não trazendo grandes impactos na prática e nem no modo de pensar e de agir dos professores. Pois, segundo Imbernón (2010), basicamente o que apoia a formação que vem de fora para dentro é a ideia de treinamento a qual prescreve técnicas e comportamentos a serem reproduzidos pelos professores sem passar pela contextualização, pela reflexão, pela crítica e tenta resolver um ilusório problema comum.

Se a diversidade social é evidente, a diversidade de situações educativas no contexto escolar também é realidade influenciando e sendo influenciada pelo contexto. Como então pressupor uma formação generalizada que venha atender às demandas singularizadas que surgem de contextos de igual modo singulares? A alternativa que ora visualizo a essa formação continuada padronizada é a sua substituição por uma formação que nasça das situações reais que surgem nas unidades escolares.

Segundo Nóvoa (2011, p. 6), “[...] é preciso passar a formação de professores para dentro da profissão", pois para ele, "não haverá nenhuma mudança significativa se a "comunidade dos formadores de professores" e a "comunidade dos professores" não se tornarem mais permeáveis e imbricadas".

O referido autor, fazendo uma analogia com a formação dos médicos traz quatro lições que julga serem fundamentais para influenciar a formação docente:

[...] a referência sistemática a casos concretos, e o desejo de encontrar soluções que permitam resolvê-los, [...] a importância de um conhecimento que vai para além da "teoria" e da "prática" e que reflete sobre o processo histórico da sua constituição, [...] a procura de um conhecimento pertinente, que não é uma mera aplicação prática de uma qualquer teoria, mas que exige sempre um esforço de reelaboração, [...] a importância de conceber a formação de professores num contexto de responsabilidade profissional, sugerindo uma atenção constante à necessidade de mudanças nas rotinas de trabalho, pessoais, coletivas ou organizacionais. A inovação é um elemento central do próprio processo de formação. (NÓVOA, 2011, p. 52-53).

É partindo dessa ótica que defendo a formação dentro do espaço escolar, ou seja, no espaço/tempo da coordenação pedagógica, a partir das questões que brotam do chão da 
escola, pois a formação, nessa perspectiva, favorecerá a reflexão coletiva sobre o trabalho pedagógico e mobilizará conhecimentos que se constituirão não só em um importante salto no processo pedagógico, mas também em um exemplo de responsabilidade e de compromisso com a comunidade escolar e a sociedade de modo geral.

Nesse sentido, a reflexão partilhada coletivamente não será apenas uma mera palavra escrita no Projeto Político Pedagógico, será concreta. Nenhum professor se resignará com o fracasso dos alunos, ao contrário, iniciará um movimento real no sentido de efetivar a melhoria da qualidade do ensino e a mudança da prática docente na busca pela efetivação da aprendizagem e da transformação da realidade social.

Ao defender a formação continuada nessa perspectiva não estou afirmando categoricamente que esse é $o$ modo de formar professor, mas acredito que é $u m \operatorname{modo}{ }^{6}$ de formação que pode gerar a reflexão dos professores sobre o próprio trabalho, a conscientização crítica a respeito da sua condição de agente social e favorecer ainda, a criação de novas estratégias de ensino que possibilitem a aprendizagem dos alunos.

${ }^{6}$ Grifo meu. 


\section{A FORMAÇÃO CONTINUADA DOCENTE NO ESPAÇO/TEMPO DA COORDENAÇÃO PEDAGÓGICA}

Diante de uma sociedade que se autodenomina sociedade do conhecimento, o trabalho do professor se torna um tanto quanto desafiador no sentido de ter que dar conta de compreender o que está imbricado nas questões educacionais, sociais, econômicas, políticas, culturais, contemporâneas e ensinar para atender as necessidades que daí surgem.

Muitas exigências feitas hoje "[...] ultrapassam as condições de trabalho dos professores, por serem questões estruturais que atingem a todos" (FERNANDES, 2012, p. 84). Cobram deles a resolução de problemas que dizem respeito às diversas instâncias da sociedade e nessa dinâmica o professor muitas vezes se sente sobrecarregado, atordoado, sem ter a quem recorrer.

Nesse sentido, é fundamental a reflexão sobre a formação continuada docente no espaço/tempo da coordenação pedagógica como possibilidade ou impossibilidade de mudança, isto é, mudança no sentido de transformação, “[...] de fazer a crítica do saber produzido na perspectiva dominante, em suas variadas formas, e de construir um outro saber, com aquele caráter radicalmente crítico" (TONET, 2005a, p. 23), pois acredito que dependendo da perspectiva que embasa o trabalho do formador, no caso o coordenador pedagógico, os caminhos poderão ser completamente antagônicos.

É diante dessas exigências e compreendendo que o professor não tem a função de dar conta de atender às demandas que lhes são impostas pelo mundo em que vivemos, que Fernandes $(2012$, p. 88) afirma que a formação do professor precisa "[...] contemplar temas que possibilitem a reflexão crítica da realidade social, pois todos almejamos que o mundo possa ser um lugar mais justo, plural e solidário".

Ao fazer tal afirmação, em hipótese alguma quero dizer que é tarefa do professor resolver as questões da violência, das drogas, dos abusos, da indisciplina e tantas outras situações advindas da sociedade em crise e que são evidenciadas no contexto escolar. Pelo contrário, afirmo que o papel do professor deve ser de crítica ao sistema que produz essas mazelas sociais.

É nessa certeza que considero que a formação de professores deve se desenvolver na perspectiva da consolidação da educação crítica e emancipadora, na qual ele poderá compreender seu papel nessa trama social e considerar o contexto no qual está situado. Mas, para que isso verdadeiramente se torne realidade, a formação continuada docente que 
acontece no espaço/tempo da coordenação pedagógica deverá levar o professor a pensar e agir em favor do lado social mais fragilizado, pois como afirma Veiga (2012, p. 21), “[...] precisamos inovar, urgentemente, a proposta de formação de professores a fim de atender as necessidades dos alunos provenientes das camadas mais pobres da população".

É premente a necessidade de se abrir os olhos para as contradições sociais e se ter consciência de que o professor não pode e nem será o grande "salvador da pátria", mas poderá assumir a sua condição de agente social. Nesse sentido,

[...] as perspectivas de formação devem ser analisadas no âmbito do contexto social mais amplo, bem como no bojo da concepção de profissão, profissionalismo e profissionalização. É preciso, também, perceber como os profissionais do magistério vêm inserindo-se nesse cenário e quais os limites e as possibilidades do desempenho de suas tarefas no cotidiano das escolas. Temos que estar conscientes da necessidade de articular, dialeticamente, as diferentes dimensões da profissão docente: científica, técnica, político-social, psicopedagógica, ética, estética e cultural (VEIGA, 2012, p. 21).

Formar o professor consciente do seu papel transformador e sensível às questões sociais significa necessariamente fortalecer o aluno para enfrentar e transformar sua condição social. Nessa perspectiva, caberá ao formador, no caso, o coordenador pedagógico, a responsabilidade de iniciar o movimento de fortalecimento do trabalho coletivo e de propor ações que ajudem o grupo a superar a fragmentação do trabalho pedagógico.

Quando o trabalho pedagógico é pautado na individualização, segue na contramão das transformações sociais e fortalece a subsunção do trabalho docente ao rígido roteiro estabelecido pela burguesia, levando a escola a perder cada dia mais o seu valor e a sua posição privilegiada de construtora e disseminadora de conhecimentos (FERNANDES, 2012).

Sendo assim, pensando com Fernandes (2012), surgem mais alguns questionamentos: a qual formação me refiro? Formar o professor com que finalidade e a partir de qual perspectiva? Uma formação tradicional que concebe as práticas instrumentais como garantia de resolução dos problemas da sala de aula totalmente baseada na racionalidade técnica?

Observo que nenhuma estrutura escapa das contradições próprias do capital, fato constatado inclusive nos discursos políticos oficiais da atualidade, pois essa racionalidade não mais se esconde, ela se expõe e a cada dia reafirma o seu papel no contexto educacional e no contexto da formação docente.

Acredito que o espaço/tempo da coordenação pedagógica pode ser de fato utilizado para a formação docente na perspectiva crítica, mas de igual modo pode se colocar a 
serviço do ideal capitalista, dependendo apenas da perspectiva na qual se tem construído a consciência dos formadores e, consequentemente, dos docentes que se formam naquele espaço.

É nesse cenário que defendo a formação continuada do docente no espaço/tempo da coordenação pedagógica como possibilidade de desenvolvimento do olhar crítico do professor e que este promova "avanços na prática pedagógica, na organização do trabalho pedagógico e na reivindicação de melhores condições de trabalho e qualidade das escolas públicas" (FERNANDES, 2012, p. 89).

Através da problematização das questões que envolvem o próprio ambiente de trabalho do professor, o agir e o pensar docente, essa formação contextualizada se constituirá como importante fonte de produção de saberes que possibilitam a ampliação da visão crítica dos professores para além do contexto vivido. Caberá ao grupo a sua valorização.

\subsection{Um olhar histórico sobre a coordenação pedagógica: perspectiva histórica}

O ato de supervisionar é muito antigo. Segundo Saviani (2002), a função supervisora já se fazia presente nas comunidades primitivas, pois nessas comunidades o modo de produção ainda era coletivo, ou seja, os homens ainda não estavam separados em classes sociais e produziam tudo em comum.

Dessa forma, iam se educando e educando as novas gerações, a educação acontecia com a própria vida. Nesse período, já se fazia presente a função supervisora, isto é, os adultos educavam os mais novos e por meio de uma vigilância discreta, os protegiam e os orientavam supervisionando-os e ajudando-os nas suas dificuldades (SAVIANI, 2002).

A partir do momento que o homem se fixou na terra, dando origem à propriedade privada e criando a divisão da sociedade em classes, os proprietários se tornaram dominadores tendo servos e escravos debaixo de seu jugo. Com essa nova configuração social, a educação assume novos contornos e surge daí a escola, que era chamada de lugar do ócio, onde só a classe dominante dispunha de tempo livre para frequentá-la, pois a classe menos favorecida era educada pelo trabalho.

No período antigo e medieval, a escola tinha uma estrutura simples e elementar baseada na relação dos mestres com os discípulos onde a função supervisora se caracterizava no trabalho de acompanhamento dos trabalhos e atividades do discípulo pelo mestre. Ela 
acontecia na ação do mestre por meio do controle, da fiscalização e até mesmo da coerção, expressa nas punições e castigos físicos.

$\mathrm{Na}$ Grécia, a supervisão se estabelecia na figura do pedagogo ${ }^{1}$ que tinha por função vigiar, controlar, supervisionar todos os atos das crianças e levá-los ao paedagogium ${ }^{2}$. A função supervisora também se fazia presente na educação - vigilância - dos trabalhadores escravos pelo intendente ou capataz.

No período moderno, estabeleceram-se relações sociais de dominação que não permitiam mais o pleno acesso ao saber, a cultura não era mais produzida de modo espontâneo e sim de forma deliberada e sistemática, o que impulsionou a generalização da escola, pois foi por meio dela que o povo passou a ter acesso à cultura.

Com a apropriação da ciência pelo processo produtivo, o ensino passou a se constituir em uma atividade voltada para atender às demandas do mercado, necessitando de trabalhadores formados e qualificados profissionalmente. Com esse processo de institucionalização da educação, a ideia de supervisão pedagógica começa a ser esboçada evidenciando-se na organização da instrução pública.

O ato de supervisionar no Brasil despontou na educação jesuítica no século XVI. Contudo, é somente após a morte do Padre Manoel de Nóbrega (1570) que passaram a adotar um plano de estudos chamado Ratio Studiorum ${ }^{3}$. Como destaca Soares (2012, p. 75), “[...] esse conjunto de normas ganha força quando copia o modelo de supervisão dos Estados Unidos, cuja principal função é a Inspeção Escolar, pautada na "super" visão como forma de desenvolver certo controle dos professores e alunos".

A figura do Prefeito de Estudos tinha caráter supervisor, e de auxiliar do reitor, cujas funções eram reguladas por trinta regras ${ }^{4}$, dentre as quais algumas relacionadas à supervisão onde se estabeleceram ser dever do Prefeito, organizar os estudos, orientar e dirigir as aulas; se incumbir de lembrar aos professores que deveriam explicar toda a matéria de modo a esgotar toda a programação; ouvir e observar os professores e, de vez em quando, assistir suas aulas e também ler os apontamentos dos alunos (SILVA, 2006).

\footnotetext{
${ }^{1}$ Escravo que tomava conta das crianças e os conduzia até o mestre. Fonte: <http://pt.wikipedia.org/wiki/Pedagogia>. Acesso em: 16 out. 2013.

${ }^{2} \mathrm{O}$ chamado Pedagogium foi a instituição para educar crianças escravas destinadas a servir as classes superiores, lá aprendiam a leitura e a escrita. Não está claro que tipo de ensino foi oferecido, às vezes foi ensinado ler e escrever, mas com mais frequência as fontes falam de educação para preparar e servir os alimentos. Fonte: <http://it.wikipedia.org/wiki/Paedagogium> (Original em italiano). Acesso em: 18 out. 2013.

${ }^{3}$ Linhas mestras da organização didática criadas para regulamentar o ensino nos colégios jesuíticos. Ganhou status de norma para toda a Companhia de Jesus. Foi ponte entre o ensino medieval e o moderno.

${ }^{4}$ Regras do Ratio Studiorum. Fonte:

<http://www.histedbr.fae.unicamp.br/navegando/fontes_escritas/1_Jesuitico/ratio\%20studiorum.htm>. Acesso em: 22 out. 2013.
} 
Com a Reforma Pombalina e a expulsão dos jesuítas do Brasil extinguiu-se o sistema de ensino jesuítico e dessa forma, diluiu-se o caráter orgânico da função supervisora.

Entretanto, o Alvará de 28 de junho de 1759, que expulsou os jesuítas, previa a criação do cargo de Diretor Geral dos Estudos, assim como a designação de comissários para fazerem o levantamento do estado das escolas. Nesse caso, a ideia de supervisão envolvia os aspectos políticos-administrativos na figura do Diretor Geral e a direção, fiscalização, coordenação e orientação do ensino aos comissários ou Comissão de Diretores de Estudos sempre sob a orientação do Diretor Geral.

Com a independência do Brasil, a Lei Geral de 15 de outubro de 1827 (BRASIL, 1827) instituiu as escolas de primeiras letras e o artigo $5^{\circ}$ da lei, determinava o estudo a partir do "Método de Ensino Mútuo", a ser trabalhado com monitores que eram alunos em estágios mais avançados de aprendizagem e que auxiliavam o professor, ensinando outros alunos mais novos ou em estágios menos avançados de aprendizagem. Esses monitores eram escolhidos pelos mestres e recebiam instrução à parte (NEVES, 2008). Nesse método, o professor assume a função de docência e também de supervisão, pois além de instruir os alunos também supervisionava os instrutores nas atividades do ensino.

No período da Regência, em 1834, com o Ato Adicional há a descentralização da educação e cada província passa a ser responsável por sua organização educacional. O ministro do Império reclama a necessidade da criação do cargo de Inspetor de Estudos. Em seu relatório declara a situação deplorável em que as escolas se encontram e ele mesmo adverte, “[...] um desses remédios teria sido o estabelecimento de uma supervisão permanente" (SAVIANI, 2002, p. 23).

Em 1854, com a Reforma Couto Ferraz, se estabeleceu como missão do Inspetor supervisionar todas as escolas, cabendo a ele também, presidir os exames dos professores e conferir-lhes os diplomas, autorizar a abertura de escolas particulares e também fazer a correção dos livros. Nesse período entra em pauta a necessidade de se organizar um sistema nacional de educação, baseado na organização administrativo-pedagógica do sistema e a ideia de supervisão se fortalece a partir dessa necessidade de organização dos serviços educacionais.

Em 1892, a Reforma Benjamim Constant cria o Conselho Superior da Instrução Pública, com a finalidade de assessorar o Ministério da Instrução Pública no controle das escolas de ensino superior. A Reforma Rivadária, de1911, instituiu o Conselho Nacional de Educação e o Conselho Superior de Ensino. E a Reforma Rocha Vaz, de 1925, transmuda o 
Conselho Superior de Ensino em Conselho Nacional de Ensino (CURY, 2000). Nesses meandros, há a predominância de atribuições burocráticas do Inspetor em detrimento das técnico-pedagógicas.

Carneiro Leão, quando Secretário de Interior, Justiça e Educação, em 1929-1930, com a Reforma nos Estados em Pernambuco, afirma a prioridade da criação de uma diretoria técnica para a educação. Ele acreditava que já passava da hora de o Estado romper com os modelos de organização educacional que confundiam a parte administrativa com a parte técnica da educação e essa separação foi condição para o surgimento da figura do supervisor diferenciada da figura do inspetor e, também, da figura do diretor. Ao diretor coube coordenar a parte administrativa e ao supervisor, coordenar a parte técnica da educação.

Apesar de toda essa longa trajetória, essa Coordenação Pedagógica somente é estabelecida pela primeira vez em 1931 com a Reforma Francisco Campos, por meio do decreto n. 19.890, de 18 de abril (BRASIL, 1931). O Decreto se referia às tarefas de acompanhamento pedagógico, “[...] porém com a nomenclatura de Inspeção Escolar, assumindo, no entanto, um papel bem diferente daquele que vinha sendo realizado: o de fiscalizar e de inspecionar o trabalho docente" (SOARES, 2012, p. 75), cabendo "[...] também ao inspetor geral presidir os exames dos professores e lhes conferir o diploma, autorizar a abertura das escolas e até rever os livros, corrigi-los ou substituí-los por outros" (SAVIANI, 2002, p. 23). Como podemos observar, a inspeção escolar à época era muito rígida e o inspetor apenas aparecia na escola para fiscalizar, desde o trabalho administrativo até o pedagógico.

Em 1932, com o Manifesto dos Pioneiros da Educação Nova formula-se um plano conjunto para reconstrução educacional no país e inicia-se um período de grande valorização dos meios de organização dos serviços educacionais, ganhando relevância a figura dos técnicos, também chamados de especialistas em educação, entre eles, o supervisor.

A Lei Orgânica do Ensino Secundário que foi promulgada pelo Decreto-Lei 4.244 de 09 de abril de 1942 (BRASIL, 1942), em seu artigo 75, parágrafo $1^{\text {o }}$ menciona: “A inspeção far-se-á, não somente sob o ponto de vista administrativo, mas com o caráter de orientação pedagógica", assumindo, assim, o caráter de inspeção.

$\mathrm{Na}$ década de 1950, “[...] a nomenclatura inspetor é alterada para Coordenador Pedagógico" (SOARES, 2012, p. 76), mas essa nomenclatura foi atribuída aos profissionais que atuariam no ensino primário, aos que atuariam no ensino superior, atribuiu-se o nome de supervisor. 
Em meio a muitas mudanças políticas, na década de 1960, a educação passou explicitamente a atender os interesses econômicos e de segurança do país (LIMA, 2013). O Parecer $n^{\circ}$ 252/1969 de 11 de abril, do CFE, reformulou o curso de Pedagogia, buscou especializar o professor fragmentando sua formação em diversas funções denominando-as, habilitações. Eram quatro habilitações na área técnica sendo elas: administração, inspeção, supervisão e orientação.

[...] com as demais habilitações educacionais criadas e oficialmente institucionalizadas na educação brasileira, a partir da regulamentação da lei 5540/68, a supervisão escolar passa a ter sua formação em cursos de graduação, sendo processada a partir da linha em que se davam os cursos de graduação promovidos pelo Pabaee e Pamp. Isto é, fundamentada nos pressupostos da pedagogia tecnicista - que se apoia na neutralidade científica e se inspira nos princípios da racionalidade, eficácia e produtividade do sistema (SAVIANI, 1988, p. 15).

Nesse contexto, no anseio da pedagogia tecnicista que se instalou, era preciso garantir a eficiência e a produtividade do processo educativo aplicando a taylorização ao trabalho pedagógico. Assim, o Coordenador Pedagógico assumiu o “[...] papel de controlar a qualidade e promover a melhoria do ensino; acreditava-se que controlando a ação docente e fiscalizando a prática pedagógica promover-se-ia a melhoria do ensino" (SOARES, 2012, p. 76).

Na década de 1970, com a Lei de Diretrizes e Bases do Ensino de $1^{\circ}$ e $2^{\circ}$ graus, lei 5.692/71 (BRASIL, 1971) oficializou-se a profissão do Supervisor pedagógico, porém, foram surgindo questionamentos no sentido de desmascarar a pretensa neutralidade com que se buscava justificar o caráter técnico da educação, centrado na diversidade de habilitações pedagógicas, em detrimento de sua dimensão política, pois para Saviani (2002, p. 106) "a função do supervisor é uma função precipuamente política e não principalmente técnica", quanto mais ela se apresentar com caráter técnico, tanto mais será eficaz na defesa dos interesses econômicos socialmente dominantes.

Chegando aos anos de 1990, “[...] retoma-se a supervisão com a LDB n. 9394/96 que propõe que a formação de especialistas seja oferecida nos Cursos de Pedagogia em nível de Pós-Graduação ou Complementação, com o intuito de formação em exercício das práticas pedagógicas" (SOARES, 2012, p. 77). Propõe, ainda, como essas práticas devem ser desenvolvidas colocando o Coordenador como responsável por contextualizar, auxiliar, pesquisar, coordenar as atividades pedagógicas em parceria com os professores (SOARES, 2012). 
Atualmente, com o Projeto de Lei n. 4.106, de 2012, o Congresso Nacional decretou a regulamentação da profissão de Supervisor Educacional dizendo:

\begin{abstract}
Art. $2^{\circ} \mathrm{O}$ Supervisor Educacional tem como objetivo de trabalho articular crítica e construtivamente o processo educacional, motivando a discussão coletiva da Comunidade Escolar acerca da inovação da prática educativa a fim de garantir o ingresso, a permanência e o sucesso dos alunos, através de currículos que atendam as reais necessidades da clientela escolar, atuando no âmbito dos sistemas educacionais Federal, Estadual e Municipal, em seus diferentes níveis e modalidades de ensino e em instituições públicas e privadas.

Parágrafo Único: O Supervisor Educacional coordenará e irá contribuir nas atividades de planejamento, execução, controle e avaliação do Projeto Político Pedagógico, juntamente com os demais especialistas, direção e professores da Unidade Educativa.

Art. $3^{\circ} \mathrm{O}$ exercício da profissão de Supervisor Educacional é exclusivo dos portadores de diploma de curso superior em Pedagogia ou em nível de pósgraduação devidamente registrado e reconhecido pelo Conselho Nacional de Educação, nas seguintes modalidades:

I - de licenciatura plena em Pedagogia e/ou Habilitação em Supervisão Escolar;

II - de pós-graduação em Supervisão Educacional.

Parágrafo Único: Os diplomas expedidos por instituições estrangeiras devem obedecer ao disposto no parágrafo $2^{\circ}$ do art. 48 da Lei $n^{\circ} 9.394$, de 1996, que

"Estabelece as diretrizes e bases da educação nacional”. (BRASIL, 2012).
\end{abstract}

Identifico no texto do Projeto de Lei n. 4.106, de 2012 (BRASIL, 2012), alguns problemas no que se refere à concepção que traz em si explicitada nos termos utilizados. Vou brevemente pontuar alguns para fortalecer a crítica ao distanciamento do instituído, do possível e do necessário.

A palavra crítica é utilizada, mas vem dissociada de um contexto mais amplo, não se esclarece o que se pretende criticar nem para que criticar. Entendo que o ato de criticar deve vir embasado em um pressuposto que favoreça transformações tanto nos que a concretizam, assim como no contexto para o qual ela foi dirigida.

Outro ponto a ser observado que dá margem para inúmeras discussões é o trecho que se refere à inovação da "prática educativa a fim de garantir o ingresso, a permanência e o sucesso dos alunos através de currículos que atendam as reais necessidades da clientela escolar" (BRASIL, 2012), mas vou por partes.

Primeiro, considerando as discussões para a inovação da prática ficam claros os pressupostos hegemônicos com uma "pedagogia que desvaloriza o conhecimento escolar e uma epistemologia que desvaloriza o conhecimento teórico/científico/acadêmico" (DUARTE, 2003, p. 602) que emerge não para transcender o pragmatismo neoliberal, mas para reforçá-lo.

Em segundo lugar, o texto traz a expressão: garantia de ingresso e de sucesso dos alunos através de currículos. Mas, será que as discussões suscitadas pelo supervisor 
pedagógico teriam o poder de garantir algo? E teriam a função de assegurar o ingresso do aluno na instituição e o sucesso na vida escolar?

Sabe-se que a repetência e a evasão são problemas que se evidenciam a cada dia e entendo que uma prática competente do supervisor pedagógico - Coordenador, no caso do DF, pode até levar à constituição de um grupo bem articulado, autônomo e cônscio do seu papel histórico na educação (FERREIRA, 2012), sentindo-se capaz de contribuir para as transformações sociais necessárias, mas não com o poder de garantir coisa alguma. Até porque a garantia tanto do ingresso dos alunos, de seu sucesso e de currículos inovadores vai além da vontade de um único indivíduo.

Terceiro ponto a ser refletido é o da utilização do termo controle. Segundo Ferreira, há de fato a necessidade de controle no trabalho educacional para que ele seja redefinido e construa uma nova pedagogia. Assim,

o controle necessário é o que se fará na construção coletiva do projeto acadêmico/educacional à luz dos princípios e elementos mencionados e do saber e do saber científico na sua forma mais elaborada, que possibilite o domínio de conteúdos e de habilidades cognitivas superiores, que devem ser estudados, discutidos, rediscutidos e incorporados à prática supervisora que o profissional da educação deverá exercer no âmbito educacional/escolar. (FERREIRA, 2012, p. 99).

Entretanto, considerando a racionalidade que estabelece as relações e institui a legislação, vale atentar para que o termo não seja utilizado no sentido de frear ou de cercear o pensamento e o agir pedagógico dos professores levando-os a se submeterem ao pensamento dominante e à perpetuação da sua ideologia.

E, por último, no que diz respeito a quem pode assumir a função de supervisor pedagógico, talvez por ser uma lei recente, o Distrito Federal ainda não se adequou a ela, permitindo que professores que tenham todo tipo de licenciatura e não tenham a especialização em supervisão pedagógica assumam o cargo que é comissionado e normalmente feito por meio de convite pelo próprio diretor da unidade educacional a um professor.

Depois desses apontamentos e da viagem histórica empreendida, compreendo que a questão da identidade do Coordenador Pedagógico foi, é, e continuará em discussão, mas o desafio que se coloca hoje para ele é: $\mathrm{O}$ seu trabalho poderá se restringir apenas ao contexto pedagógico?

Espero que a resposta a essa pergunta seja negativa, pois desejo que o trabalho de coordenar, mesmo sendo precipuamente pedagógico, transcenda as questões pedagógicas e 
passe a considerar questões políticas e sociais do contexto atual, contribuindo para o desenvolvimento de uma consciência que promova a transformação da atual configuração social.

\subsection{A Coordenação Pedagógica no Distrito Federal}

Apresento aqui um breve histórico da estrutura da coordenação pedagógica na rede pública de ensino do Distrito Federal para possibilitar o conhecimento de elementos para a compreensão da dinâmica em que a coordenação pedagógica ocorre.

Para isso, passo a relatar a respeito dos vários tipos de estruturas que já fizeram parte da organização pedagógica da Secretaria de Estado de Educação do Distrito Federal, bem como a estrutura organizacional que atualmente está em vigor.

Tal reconstituição e análise se fazem necessárias porque retratam as implicações das reformas educacionais para a construção da identidade dos coordenadores pedagógicos e a consolidação do espaço/tempo da coordenação pedagógica e sua contribuição no processo de formação continuada do docente.

O espaço/tempo da coordenação pedagógica no DF teve várias configurações, isto é, passou por várias mudanças. Fernandes (2007), em sua pesquisa de mestrado se refere a um estudo datado de 1969 que tem por título, O ensino primário no Distrito Federal. A autora destaca que o documento se refere a um "horário complementar", em que os professores com a carga horária de 20 horas semanais em regência de classe, tinham também 4 horas semanais em turno contrário ao da regência de classe como horário complementar, as atividades eram realizadas pelos Orientadores de Ensino e esse horário era destinado ao planejamento e avaliação dos estabelecimentos de ensino, de acordo com as diretrizes da época.

Além dessas atividades, também eram desenvolvidas ações de formação continuada:

[...] desencadeamos o seguinte esquema de ação:

a) Treinamento de professores para $1^{a}$ fase, em cursos especiais e em serviço;

b) Treinamento de orientadores e diretores para acompanhamento do trabalho e orientação aos professores. Essa orientação é feita semanalmente em 4 (quatro) horas do chamado horário complementar;

c) Organização de uma equipe central para a supervisão dos trabalhos de $1^{a}$ fase, com professores de reconhecida experiência no trabalho de alfabetização;

d) Estabelecimento experimental de equipes de professores especializados em alfabetização em duas escolas em Taguatinga, para aulas de demonstração e descentralização do trabalho de supervisão da $1^{\text {a }}$ fase. (DISTRITO FEDERAL, 1969, p. 17). 
É interessante destacar aqui as expressões "treinamento", "acompanhamento", “orientação" e "supervisão" como princípios da ação dos orientadores de ensino na época, bem como "aulas de demonstração" o que equivale dizer que neste período ainda não havia a perspectiva da formação como reflexão do próprio trabalho e nem a construção coletiva das ações educativas.

Fernandes (2007), afirma ainda, que desde 1979, como resultado de acordos coletivos entre o Sindicato dos Professores do Distrito Federal (SINPRO/DF) e o Governo do Distrito Federal, os professores 40h passaram a ter a carga horária dividida em 32h/semanais de regência de classe e $8 \mathrm{~h}$ de coordenação. E nessas horas de coordenação, a formação continuada no local de trabalho acontecia de forma isolada, por meio de estudos individuais.

Entretanto, também havia momentos nas Escolas de Aplicação e nos Centros de Alfabetização, que eram unidades de ensino nas quais os professores planejavam e davam aulas-modelo para outros professores da rede pública, como forma de compartilhar e disseminar conhecimentos práticos. Nesse momento, a formação continuada dos professores era marcada pela prescrição de receitas para ensinar o professor a dar boas ${ }^{5}$ aulas.

O coordenador pedagógico não tinha como função refletir sobre o fazer pedagógico para propor mudanças, e nem tão pouco se percebia como produtor de conhecimento. Dessa forma, tinha sua ação baseada na perspectiva da racionalidade técnica, na qual ele deveria adotar um posicionamento essencialmente técnico, tendo como foco principal sua instrumentalização técnica para que ele se constituísse um técnico eficiente. Essa racionalidade perdurou até meados dos anos de 1980.

Na segunda metade da década de 1990, a rede pública de ensino do Distrito Federal, adotou uma proposta pedagógica que foi intitulada de Escola Candanga: Uma lição de cidadania, projeto pedagógico do Governo Democrático e Popular liderado pelo então governador, Cristovam Buarque. Tal proposta concebia a prática da construção coletiva como princípio da democracia como uma invenção e construção cultural e

[...] se distanciava das concepções neoliberais por defender uma nova qualidade de ensino que, vinculada a valores éticos e humanistas tinha sua origem na cooperação e não na competição. Sugerindo a construção de um currículo contrário ao tecnicismo e próximo do interacionismo sócio-histórico, vislumbra no professor um mediador do processo ensino-aprendizagem". (SOUSA, 2008, p. 130).

${ }^{5}$ Grifo meu. 
A referida proposta trouxe a implantação dos ciclos de aprendizagem, se autodenominava "revolucionária" e negava o título de "reformista" (DISTRITO FEDERAL, 1996, p. 20), “[...] sua natureza transformadora a fez assumir o compromisso de questionar a realidade, apontar mecanismos para sua superação e defender a criação coletiva de uma nova cultura escolar" (SOUSA, 2008, p. 129), trazendo novas concepções sobre o fazer pedagógico ao mencionar:

Compreendemos o trabalho como uma atividade coletiva, por meio da qual os homens transformam e humanizam, ao mesmo tempo, a natureza e a si mesmos. Nas escolas, a discussão sobre organização do trabalho tem provocado inquietação e, consequentemente, mudanças. Algumas escolas tem percebido que a rígida e desumanizadora organização do trabalho é passível de transformação. (DISTRITO FEDERAL, 1996, p. 32).

Ainda segundo Sousa (2008, p. 130), esta se trata “[...] de uma proposta pedagógica que adota uma nova lógica de organização curricular e redimensiona o tempo, o espaço e os conteúdos escolares, sugerindo o rompimento com a compartimentalização e a fragmentação das disciplinas”. É possível afirmar que realmente foi a partir dela que se teve uma nova organização para o ensino no Distrito Federal.

Nesse período, foi instituída a chamada jornada ampliada de aula, na qual a carga horária passou a ser de 25 horas semanais para a regência de classe e 15 horas semanais de coordenação pedagógica. Vale lembrar que essa ampliação foi gradativa, pois a FEDF $^{6}$ tinha como objetivo debater a nova proposta e os seus pressupostos, e com a ressignificação da coordenação pedagógica ela passou a ser “[...] concedida como um momento essencial de constituição da ação coletiva, de reflexão e troca de conhecimentos que contribuam para a construção de uma prática pedagógica eficaz, e para a implantação de uma nova qualidade de ensino nas escolas públicas do Distrito Federal” (DISTRITO FEDERAL, 1996, p. 10).

A partir dessa perspectiva, o espaço e o tempo da coordenação pedagógica confirmaram-se como propícios para discussão, reflexão, crítica e planejamento das ações coletivas, socialização de conhecimentos e informações, avaliação do processo educativo ocorrido na escola, buscando ter a realidade como base da investigação coletiva e permanente.

\footnotetext{
${ }^{6}$ A FEDF - Fundação Educacional do Distrito Federal foi constituída em 1960 em substituição da CASEB Comissão de Administração do Sistema Educacional de Brasília e vigorou até o ano 2000. Nesse mesmo ano dois decretos alteraram a gestão do sistema, o Decreto $n^{0} 21.396$ dispondo sobre a extinção da FEDF e o Decreto $\mathrm{n}^{\circ} 21.397$ instituindo uma nova estrutura administrativa transformando as fundações em secretarias e a FEDF passou a denominar-se Secretaria de Estado de Educação do Distrito Federal - SEEDF.
} 


\begin{abstract}
A construção desse espaço de coordenação pedagógica vem ocorrendo a partir de iniciativas que trazem para o centro das preocupações a realidade vivenciada pelos alunos, suas demandas, interesses, dificuldades. O educador vem destacando-se, cada vez mais, como pesquisador e investigador, problematizador de sua prática, tendo oportunidade de construir e reconstruir, em grupo, com base na discussão de referenciais teóricos, o projeto político pedagógico da escola. (DISTRITO FEDERAL, 1996, p. 34).
\end{abstract}

Contudo, em 2000, o governador Joaquim Roriz assumiu o seu $4^{\circ}$ mandato, como consequência, as políticas educacionais não tiveram continuidade e uma nova política educacional foi adotada pela até então FEDF. A jornada ampliada não foi perdida, ao contrário, foi obrigatoriamente ampliada para todas as escolas públicas de ensino fundamental. No entanto, voltou a organização seriada e ocorreu um retrocesso nas ações voltadas para a formação dos professores, pois a SEEDF, já substituindo a antiga FEDF, implantou um novo currículo para o ensino fundamental/séries iniciais que foi distribuído para as escolas públicas, todavia sem implementar momentos de discussão dos pressupostos teóricos contidos no documento o que gerou um clima de insegurança em toda a rede e grande descontentamento nos professores e coordenadores pedagógicos.

Porém, com a jornada ampliada generalizada, o professor passou a ter tempo para estudar, pesquisar, preparar materiais, compartilhar conhecimento com seus pares, se formar. A formação continuada docente passou a ser uma das atribuições do coordenador pedagógico e este teve que buscar clareza e determinar sua intencionalidade na ação pedagógica, bem como o domínio de pressupostos teóricos que embasassem tanto a sua prática como a formação que desenvolveria no espaço/tempo da coordenação pedagógica.

A partir de 2005, com a implantação do Bloco Inicial de Alfabetização (BIA), realidade vivenciada ainda hoje, a concepção de formação continuada passou a exigir mais que em outros tempos, a otimização do espaço/tempo da coordenação pedagógica.

Tal formação vem se constituindo como possibilidade de construção coletiva, de vivências significativas, de trocas para o aprimoramento do fazer pedagógico e da conscientização dos professores a respeito das diferentes dimensões da profissão docente como já vimos em Veiga (2012, p. 21), “científica, técnica, político-social, psicopedagógica, ética, estética e cultural", isto é, do seu papel de agente social.

Sendo assim, compreendo que a coordenação pedagógica é o espaço/tempo destinado à reflexão e à organização do trabalho pedagógico da escola e do professor, constituído a partir das ações e da criação de estratégias de formação continuada dos coordenadores pedagógicos para ressignificar a prática docente (FERNANDES, 2007). 
Para que essa dinâmica seja consolidada como promotora de transformações não apenas da prática docente, mas para que venha a ser estruturada e desenvolvida na perspectiva de uma proposta emancipadora, o espaço/tempo da coordenação pedagógica deverá se fortalecer " $[. .$.$] deixando de ser espaço e tempo de trabalho fragmentando, no qual poucos$ pensam e muitos executam, para se constituir em trabalho coletivo - concebido, planejado, executado e avaliado por todos" (FERNANDES, 2007, p. 85). Nele há de haver diálogo, articulação teoria e prática, aprendizagem, ensino, avaliação, formação e transformação nas práticas a partir de um movimento dialético.

Desse modo, a formação tanto dos coordenadores pedagógicos como dos professores não poderia de forma alguma ficar por conta de iniciativas individuais. Essa formação devia partir de uma iniciativa institucional, da SEEDF, sendo capaz de gerar propostas que viessem a dar sustentação às ações dos coordenadores pedagógicos no espaço/tempo da coordenação pedagógica e eles darem sustentação às ações dos professores na escola, afinal a coordenação pedagógica passou a ter a função de dar suporte às ações pedagógicas desenvolvidas na escola, como é possível observar no trecho a seguir:

Da Coordenação Pedagógica

Art. 20 - A Coordenação Pedagógica tem por finalidade planejar, orientar e acompanhar as atividades didático-pedagógicas, a fim de dar suporte à Proposta Pedagógica, promovendo ações que contribuam para a implementação das Orientações Curriculares da Secretaria de Estado de Educação em vigor.

Parágrafo único. A Coordenação Pedagógica está sob a responsabilidade do Coordenador Pedagógico, designado de acordo com a legislação vigente (DISTRITO FEDERAL, 2009, p. 21).

Percebo que essas mudanças foram cruciais para que a coordenação pedagógica fosse vista como uma possibilidade de promover momentos de inovação das práticas pedagógicas tornando-as significativas para o desenvolvimento de todos os envolvidos no contexto escolar.

O espaço/tempo da coordenação pedagógica foi conquistado pela luta da classe dos professores por melhorias nas condições de trabalho e, hoje, como se pode perceber nas normas para a coordenação pedagógica 2013, ele passou a fazer parte da estrutura organizacional escolar, de acordo com o apontado:

1. A coordenação pedagógica local abrigar-se-á no Projeto Político Pedagógico da unidade escolar, no que se refere às atividades individuais e coletivas, bem como às atividades internas e externas.

1.1 A coordenação pedagógica deverá constar do Projeto Político Pedagógico da unidade escolar. 
2. As horas de trabalho destinadas às atividades de coordenação pedagógica local constarão do horário do professor, devendo ser planejadas, cumpridas e registradas na folha de frequência.

3. Para os professores regentes que atuam 40 (quarenta) horas semanais, no turno diurno, com jornada ampliada na Educação Infantil, no Ensino Fundamental - Anos Iniciais e na Educação Especial, inclusive o professor intérprete educacional, a coordenação pedagógica dar-se-á no turno contrário ao de regência, totalizando 15 (quinze) horas semanais, devendo atender, no mínimo, a disposição abaixo:

a) as quartas-feiras destinadas à coordenação coletiva na unidade escolar;

b) as terças-feiras e quintas-feiras destinadas à coordenação pedagógica individual na unidade escolar e formação continuada;

c) as segundas-feiras e sextas-feiras destinadas à coordenação pedagógica individual, podendo ser realizada fora do ambiente da unidade escolar (DISTRITO FEDERAL, 2013b, p. 11).

Com essa organização pode-se ver favorecida "[...] a construção do espaço de discussão, a ser concretizado pela ação do coordenador pedagógico, nos momentos coletivos do trabalho de organização do fazer educativo" (ARAÚJO; MUNDIM, 2012, p. 162). E o espaço/tempo da coordenação se constituindo como lócus formativo e de transformação da prática educativa tendo coordenador e professor como protagonistas desse processo.

Considerando, então, esse espaço/tempo como histórico, político e social é possível estabelecer sua importância para a busca e a constituição de um sistema social no qual a razão humana seja reconhecida como característica imanente do homem, capaz de instrumentalizá-lo para o domínio e o controle das mais variadas práticas, sustentadas por uma conduta crítica na concretização do trabalho que emancipa.

Na Lei n 4.075/2007-DF, antigo plano de carreira dos professores, no Art. 10, já havia a garantia mínima:

[...] ao servidor da Carreira Magistério Público do Distrito Federal e do PECMP no exercício da regência de classe nas instituições educacionais o percentual de, no mínimo, $20 \%$ (vinte por cento) de sua carga horária semanal para atividades de coordenação pedagógica, na forma a ser regulamentada pela Secretaria de Estado de Educação. (DISTRITO FEDERAL, 2007, art. 10).

Hoje, com a regulamentação da Lei n ${ }^{\circ}$ 5.105, de 03 de maio de 2013 que revogou a lei anteriormente citada e instituiu o novo Plano de Carreira do Magistério Público do Distrito Federal, houve um aumento na definição do tempo destinado à Coordenação Pedagógica, tempo que de fato já era nesse percentual:

Art. 10. Ficam assegurados ao professor de educação básica, em regência de classe nas unidades escolares, os seguintes percentuais mínimos de coordenação pedagógica:

I - trinta e três por cento para regime de trabalho de vinte horas semanais; 
II - trinta e sete e meio por cento para regime de trabalho de quarenta horas semanais.

$\S 1^{\circ} \mathrm{O}$ professor de educação básica submetido ao regime de quarenta horas semanais, em dois turnos de vinte horas, tem, para cada turno, o disposto no inciso I. (DISTRITO FEDERAL, 2013a).

Não há como negar que essa organização das horas da coordenação pedagógica trouxe outras possibilidades à organização do trabalho pedagógico nas escolas e ampliou em especial as possibilidades de transformação da perspectiva da formação docente que acontece naquele espaço/tempo.

É possível visualizar mais claramente na tabela abaixo como está organizado o tempo da Coordenação Pedagógica no DF, segundo a atual portaria de distribuição de carga horária da coordenação dos professores dos anos iniciais ${ }^{7}$.

Quadro 2 - Tempo destinado à Coordenação Pedagógica nas UE de Anos Iniciais

\begin{tabular}{|c|c|c|c|c|c|}
\hline H/Dia & Segunda & Terça & Quarta & Quinta & Sexta \\
\hline \multirow{6}{*}{3} & Coordenação & Coordenação & Coordenação & Coordenação & Coordenação \\
& pedagógica & pedagógica & coletiva na & pedagógica & pedagógica \\
& individual, & individual na & unidade escolar. & individual na & individual, podendo \\
& podendo ser & unidade escolar & & unidade escolar e & ser realizada fora \\
& realizada fora & e formação & & formação & do ambiente da \\
& do ambiente da & continuada. & & continuada. & unidade escolar. \\
& unidade escolar. & & & & \\
\hline
\end{tabular}

Fonte: Elaborado pela autora. Baseado na Lei no 4.075, de 28/12/2007 (DISTRITO FEDERAL, 2007).

Com essa nova configuração, a coordenação pedagógica passou a ser responsabilidade da equipe gestora da escola, dos coordenadores locais em convergência com a Coordenação Intermediária e Central, como se pode ver no Regimento Escolar das Instituições Educacionais da Rede Pública de Ensino do DF:

Art. 22 - O planejamento e a realização da Coordenação Pedagógica Local são de responsabilidade dos integrantes da Direção da instituição educacional, bem como dos supervisores e dos coordenadores pedagógicos, com a participação da equipe de professores em consonância com as equipes de Coordenação Intermediária e Central (DISTRITO FEDERAL, 2009, p. 22).

A compreensão dessa responsabilidade compartilhada é fundamental para que seja construído um trabalho que venha a atender às demandas da educação nos dias atuais e

${ }^{7}$ Foco da minha pesquisa. 
possibilite o crescimento do coletivo que aos poucos deixará para trás as arbitrariedades, o individualismo, as impossibilidades.

É fundamental que o coletivo saia em busca de possibilidades de trabalhar para transformar não apenas a prática pedagógica, mas a dimensão social que está para além dos muros da escola, que se constitui e é constituída pelos alunos e por cada um que está envolvido no processo educativo.

Contreras afirma que

[...] a ideia de compromisso com a comunidade chama a atenção sobre o fato de que o próprio exercício da função de professor é um exercício público, que não pode responder ao exclusivo desejo ou definição construídos sobre as pretensões educativas dos profissionais, à margem da comunidade e seus interesses e valores (CONTRERAS, 2002, p. 200).

Sendo assim, compreendo que o espaço/tempo da coordenação pedagógica é um espaço de interações significativas, mas é também um espaço propício às manifestações de relações democráticas e de posicionamentos autônomos. Tais posicionamentos contribuirão "[...] para que o espaço de preocupações e decisões não se encontre limitado pela experiência presente do que hoje é a prática escolar, mas que possa ampliar seus horizontes em relação ao que deveria ser e ainda não é” (CONTRERAS, 2002, p. 203). Todavia, essa consciência não se constituirá em ações mecanizadas e irrefletidas, será constituída a partir da apropriação do sentido, do entendimento da autonomia.

De acordo Contreras, a autonomia é concebida

[...] como um processo de emancipação, pelo qual se pode ultrapassar as dependências ideológicas que impedem a tomada de consciência da função real do ensino, das limitações pelas quais nossa prática se vê submetida e da forma pela qual estas dependências são assimiladas como naturais e neutras. (CONTRERAS, 2002, p. 200).

O citado autor completa afirma que "[...] a autonomia, enquanto emancipação, requer análise das condições de nossa prática e do nosso pensamento" (CONTRERAS, 2002, p. 200) e resume a "[...] autonomia como emancipação: liberação profissional e social das opressões. Superação das distorções ideológicas. Consciência crítica. Autonomia como processo coletivo (configuração discursiva de uma vontade comum), dirigido à transformação das condições institucionais e sociais do ensino" (CONTRERAS, 2002, p. 193).

Logo, o trabalho do professor deverá partir das demandas da comunidade, mas deverá ir além, superando as ideologias controladoras que tem colocado a educação em 
condição de subserviência às suas vontades e dar condições ao professor de desempenhar seu papel de forma crítica resistindo e denunciando as injustiças, a marginalização e a dominação presentes na sociedade, encerrando um ciclo de reprodução e reforço de tais mazelas.

Contudo, apesar dessa dimensão colaborativa que o espaço/tempo da coordenação pedagógica pode desenvolver, caberá ao coordenador se constituir em uma liderança pedagógica e gerar ações que vão sustentar o trabalho pedagógico e a formação continuada docente na escola como indicado a seguir:

\footnotetext{
Art. 21 - O Coordenador Pedagógico deverá:

I - participar da elaboração, da implementação, do acompanhamento e da avaliação da Proposta Pedagógica da instituição educacional;

II - orientar e coordenar a participação docente nas fases de elaboração, de execução, de implementação e de avaliação da Proposta Pedagógica da instituição educacional; III - articular ações pedagógicas entre professores, equipes de direção e da Diretoria Regional de Ensino, assegurando o fluxo de informações;

IV - divulgar e incentivar a participação dos professores em todas as ações pedagógicas, promovidas pela instituição educacional, pela Diretoria Regional de Ensino e pela Subsecretaria de Educação Básica, inclusive as de formação continuada;

V - estimular, orientar e acompanhar o trabalho docente na implementação das Orientações Curriculares da Secretaria de Estado de Educação do Distrito Federal, por meio de pesquisas, de estudos individuais e em equipe e de oficinas pedagógicas locais;

VI - divulgar, estimular e propiciar o uso de recursos tecnológicos, no âmbito da instituição educacional, com as orientações metodológicas específicas;

VII - orientar os professores recém-nomeados e recém-contratados quanto ao desenvolvimento da Proposta Pedagógica;

VIII - propor reflexão avaliativa da equipe, objetivando redimensionar as ações pedagógicas; e

IX - propor ações educativas que visem ao avanço de estudos e a recuperação do processo de ensino e aprendizagem. (DISTRITO FEDERAL, 2009, p. 21).
}

Vê-se nesse trecho que o coordenador pedagógico tem a incumbência de se constituir como liderança formadora. Mas, muitos questionamentos surgem daí: Será que a formação que ele tem recebido o coloca em condição de desencadear tais ações formativas? Será que o coletivo tem se engajado na tarefa de constituir a sua identidade de sujeitos ativos e autônomos? Ou será que ao lerem esse trabalho veem apenas a prescrição de ações voltadas para atender às demandas do dia a dia escolar, não trazendo em si a preocupação de favorecer o reconhecimento do conhecimento científico como mola propulsora da consciência crítica na conquista da maturidade e da autodeterminação na busca pela emancipação humana?

Nesse sentido, torna-se imprescindível trazer os pressupostos legais que estão vigorando atualmente no âmbito das escolas públicas do Distrito Federal e que tratam da coordenação pedagógica como espaço/tempo destinado à formação docente para uma análise no sentido de suscitar questionamentos que levem tanto coordenadores quanto professores a 
refletirem sobre sua condição de sujeitos passivos ou ativos no processo social do qual a educação e cada um faz parte.

Trago então, pontos da legislação que versam sobre o tema. Destaco que a Lei $n^{\circ}$ 4.075 de 28/12/2007, de acordo com o Art. $2^{\circ}$, inciso X, apresentava a coordenação pedagógica como: “conjunto de atividades destinadas à qualificação, ao aperfeiçoamento profissional e ao planejamento pedagógico que, desenvolvidas pelos docentes, dão suporte à atividade de regência de classe". (DISTRITO FEDERAL, 2007, art. $2^{\circ}$ ).

E a comparo com a lei atual, $\mathrm{n}^{\circ} 5.105$, de 03 de maio de 2013 em seu Art. 2, inciso IX, “A Coordenação Pedagógica: é o conjunto de atividades destinadas à qualificação, à formação continuada ${ }^{8}$ e ao planejamento pedagógico que, desenvolvidas pelos docentes, dão suporte à atividade de regência de classe”. (DISTRITO FEDERAL, 2013a, art. $2^{\circ}$ ).

Vê-se ai a modificação dos termos buscando agora uma adequação aos anseios que eclodem no meio educacional e estão, hoje, nos livros e nas pesquisas, mas, além disso, trazem em si uma conotação mais ampla do que deve acontecer no espaço/tempo da coordenação pedagógica e deve ser destinado ao desenvolvimento da formação docente em sua amplitude.

No entanto, será que a pura mudança dos termos poderá influenciar no que de fato acontece no espaço/tempo da coordenação pedagógica? Ou a lógica seria o contrário? Ou a lógica vai além da utilização dos termos? Será que essa alteração por si só pode levar coordenadores e professores à reflexão e a superação do que o sistema lhes tem imposto como verdade intransponível? Acredito que não. Afinal, toda e qualquer legislação que seja idealizada sem uma “[...] sólida base metodológica de caráter histórico-ontológico, faz com que sua apropriação teórica do processo social não consiga ultrapassar o nível da superficialidade" (TONET, 2005b, p. 4) e não se coloca em condições de ir além do capital.

De todo modo, vejo a importância da regulamentação legal que versa sobre a coordenação pedagógica, o seu tempo, o seu espaço, a sua característica, a sua função, como são apresentadas nas leis e nas portarias citadas.

Vejo, igualmente, a importância da mobilização dos professores em obter conquistas significativas como a ampliação do tempo destinado à coordenação pedagógica, mas destaco que não basta apenas a letra da lei para garantir o direito, tem que haver a conscientização de todos os profissionais da educação sobre a importância da valorização dessas conquistas, utilizando de fato esse espaço/tempo para a efetiva organização do trabalho

\footnotetext{
${ }^{8}$ Grifos meus.
} 
pedagógico e para a formação docente, com o firme propósito de consolidar a coordenação pedagógica como espaço de reflexão, de crítica, de aprendizado e de transformações.

Até aqui me detive em falar apenas do coordenador pedagógico, mas esclareço que aqui no DF, existe a figura de dois profissionais que atuam no espaço/tempo da Coordenação Pedagógica, o Supervisor Pedagógico e o Coordenador Pedagógico, porém, nem todas as escolas tem o direito de ter o Supervisor Pedagógico.

A LDB determina que o DF e os estados organizem o seu próprio sistema de ensino, então na organização educacional da SEEDF hoje, nem todas as Unidades de Ensino fazem jus ao Supervisor Pedagógico.

De acordo com a Portaria $n^{\circ}$ 34, de 05 de fevereiro de 2013 (BRASIL, 2013c), considerando o resultado do Censo Escolar do Distrito Federal de 2012 a SEEDF estabeleceu a distribuição dos Supervisores nas Unidades Escolares de acordo com o número de alunos como podemos ver no quadro abaixo:

Quadro 3 - Quadro de Quantidade de Supervisores Pedagógicos por UE

\begin{tabular}{|c|c|c|c|c|c|}
\hline \multirow{2}{*}{ Tipologia } & \multirow{2}{*}{ Funcionamento } & \multicolumn{4}{|c|}{ Quantidade de estudantes por supervisores } \\
\hline & & Até 300 & $\begin{array}{c}\text { De } 301 \text { até } \\
1.000\end{array}$ & $\begin{array}{c}\text { De } 1.001 \text { até } \\
2.000\end{array}$ & Acima de 2.000 \\
\hline $\begin{array}{l}\text { - Jardim de Infância } \\
\text { - Escola Meninos e } \\
\text { Meninas do Parque }\end{array}$ & Diurno & - & 1 & 2 & 3 \\
\hline \multirow{2}{*}{$\begin{array}{l}\text { - Escola Classe } \\
\text { - Centro Educacional } \\
\text { - Centro de Ensino } \\
\text { Fundamental } \\
\text { - Centro de Ensino } \\
\text { Médio }\end{array}$} & Diurno & - & 1 & 2 & 3 \\
\hline & Noturno & 1 & 1 & 2 & 2 \\
\hline $\begin{array}{l}\text { - Centro de Educação } \\
\text { Infantil }\end{array}$ & Diurno & 1 & 1 & 2 & 3 \\
\hline \multirow{2}{*}{$\begin{array}{l}\text { - Centro de Educação } \\
\text { Profissional } \\
\text { - Centro Interescolar de } \\
\text { Línguas } \\
\text { - Centro integrado de } \\
\text { Educação Física } \\
\text { - Escola Classe } \\
\text { - Escola da Natureza } \\
\text { - Escola do Parque da } \\
\text { Cidade }\end{array}$} & Diurno & 2 & 2 & 2 & 2 \\
\hline & Noturno & 2 & 2 & 2 & 2 \\
\hline $\begin{array}{lll}\text { - Centro de Ensino } \\
\text { Especial }\end{array}$ & Diurno & 2 & 2 & 2 & 3 \\
\hline \multirow{2}{*}{$\begin{array}{l}\text { - Centro de Atenção } \\
\text { Integrado a Criança }\end{array}$} & Diurno & 2 & 2 & 2 & 3 \\
\hline & Noturno & 2 & 2 & 2 & 2 \\
\hline
\end{tabular}

Fonte: Agência Brasília, portal de notícias do Governo do Distrito Federal. 
Como se pode observar, nem todas as instituições tem direito ao Supervisor pedagógico, mas nesse caso, a SEEDF garante que cada UE tenha pelos menos um coordenador pedagógico, independente do quantitativo de alunos, como nos diz o item 26 do capítulo III, da Portaria $\mathrm{n}^{\circ}$ 29, de 29 de janeiro de 2013: “todas as unidades escolares, independente do número de turmas, terão 1 (um) Coordenador Pedagógico Local de 40 (quarenta) horas semanais [... $]^{9 ”, ~(D I S T R I T O ~ F E D E R A L, ~ 2013 b) . ~}$

Essa mesma portaria também determina o quantitativo de Coordenadores Pedagógicos por UE, mas agora de acordo com o número de turmas e não com o número de alunos, como no caso dos Supervisores, como podemos ver a seguir:

26.1 Nas unidades escolares, o quantitativo de Coordenadores Pedagógicos Locais será determinado pelo somatório total de turmas autorizadas na unidade escolar (Educação Infantil, Ensino Fundamental, Ensino Médio, Educação Especial e Educação de Jovens e Adultos $-2^{\circ}$ e $3^{\circ}$ segmentos), assegurando-se a seguinte proporção:

a) de 8 (oito) a 18 (dezoito) turmas: mais 1 (um) Coordenador Pedagógico Local;

b) de 19 (dezenove) a 32 (trinta e duas) turmas: mais 2 (dois) Coordenadores Pedagógicos Locais;

c) de 33 (trinta e três) a 45 (quarenta e cinco) turmas: mais 3 (três) Coordenadores Pedagógicos Locais;

d) de 46 (quarenta e seis) a 60 (sessenta) turmas: mais 4 (quatro) Coordenadores Pedagógicos Locais;

e) a partir de 61 (sessenta e uma) turmas: mais 5 (cinco) Coordenadores Pedagógicos Locais (DISTRITO FEDERAL, 2013b, p. 12).

Pela organização e determinação das funções tanto do supervisor pedagógico como do coordenador pedagógico, posso afirmar que elas praticamente se repetem e diante disso, pode-se deduzir que as UE que não possuem a figura do Supervisor terão as suas necessidades pedagógicas supridas pelo Coordenador Pedagógico.

Nos referenciais para a formação de professores (BRASIL, 1999, p. 131), no trecho que se refere ao coordenador pedagógico admite-se que este também é chamado de orientador ou supervisor, dependendo do sistema de ensino. Apesar de aqui no Distrito Federal ter nos ordenamentos a figura de ambos, escolhi os coordenadores pedagógicos e não os supervisores como sujeitos da pesquisa, primeiro pelo fato de poder encontrá-los em todas as unidades escolares e segundo por serem eles que efetivamente estão em contato com os professores e as questões que emergem do cotidiano escolar.

${ }^{9}$ Há algumas exceções. 


\subsection{O Coordenador Pedagógico e seu papel formador}

Foi reivindicação dos professores de todo o país que o processo de formação continuada dos professores viesse a ser desenvolvido em cada escola (BRUNO; CHRISTOV, 2010, p. 7), pelo fato deste ter acontecido durante anos com a saída do professor do seu local de trabalho. Contudo, “[...] há atualmente uma forte tendência em valorizar a escola como o lócus da formação contínua" (FUSARI, 2010, p. 17).

Nessa perspectiva, considero necessário afirmar que “[...] a atribuição essencial do coordenador pedagógico está, sem dúvida alguma, associada ao processo de formação em serviço dos professores" (CHRISTOV, 2010, p. 9), além de algumas outras ações que também fazem parte de suas atribuições e responsabilidades.

Considerando a trajetória histórico-política da coordenação pedagógica, é fundamental que a atuação do coordenador pedagógico objetive contribuir para as transformações possíveis e necessárias no espaço no qual atua, mas, para isso, ele terá que ter clareza das demandas da sua função não podendo se limitar a atender urgências e necessidades típicas do ambiente escolar, somente.

O coordenador pedagógico deverá ter habilidade gestora para fortalecer questões que sustentam o seu fazer pedagógico na escola. Essa habilidade servirá de apoio para que em meio aos conflitos cotidianos ele não venha a cair em profunda frustração diante do que não conseguiria administrar, pois a partir do momento que o professor assume a função de coordenador pedagógico, pressupõe que compreenda as implicações dessa função.

É importante que o coordenador pedagógico se constitua formador para pautar a sua atuação de forma consciente em teorias que venham a contribuir para suscitar questões e implementar ações que favoreçam a autonomia intelectual e do fazer do professor.

Fazendo uma crítica ao trabalho do coordenador, Christov considera essencial e importante o planejamento e viabilização de oportunidades para que professores: "Analisem teorias de ensino e de educação; elaborem suas próprias teorias de ensino e educação; avaliem e replanejem suas práticas; vivam a experiência da divergência, da diferença entre concepções e situem seus modos de ver a escola, os alunos e a profissão" (CHRISTOV, 2010, p. 43).

$\mathrm{Na}$ mesma perspectiva, Orsolon (2001) afirma que quando o coordenador pedagógico, posicionando-se como formador, cria condições para que sua prática seja objeto de reflexão desencadeando o processo de formação continuada in loco, transforma o ambiente da coordenação pedagógica, a prática docente e promove sua própria constituição como 
agente formador, ela parte da crença de que os coordenadores pedagógicos são protagonistas das mudanças por meio de um movimento dialético de ruptura e continuidade.

Nesse sentido, será com a apropriação da concepção de seu papel, da sua função de formador que o coordenador pedagógico deverá a cada dia compartilhar os conhecimentos que são fundamentais para que se estabeleça e se fortaleça no ambiente da coordenação pedagógica o foco da formação numa perspectiva emancipatória. Para isso, ele deverá ter atitude de curiosidade e busca do novo para que a sua prática seja o eixo orientador de ações intencionais com a finalidade de formar e transformar o trabalho docente por meio da " [...] práxis social transformadora de um sujeito (educador) em interação situada com outro sujeito (aprendiz)" (CARNEIRO; SILVA, 2008, p. 138).

O ato de coordenar possibilitará uma formação que estruture melhor a organização do trabalho coletivo levando à construção de diretrizes que apontem onde, como e quando os professores deverão intervir e essa intervenção não será aleatória, será a partir da reflexão crítica da realidade na qual atuam. À medida que a atuação do coordenador ganha força, se constrói um espaço de colaboração voltado para o diálogo, para a participação coletiva e para o desenvolvimento da autonomia dos docentes.

Christov (2010), citando Angel Perez Goméz, em 1995, diz que ela

afirma que para se superar a racionalidade técnica, ou seja, uma utilização linear e
mecânica do conhecimento científico, é preciso partir da análise das práticas dos
professores quando enfrentam problemas complexos da vida escolar, para
compreensão do modo como utilizam o conhecimento científico, como resolvem
situações incertas e desconhecidas, como elaboram e modificam rotinas, como
experimentam hipóteses de trabalho, como utilizam técnicas e instrumentos
conhecidos e como recriam estratégias e inventam procedimentos e recursos.
(CHRISTOV, 2010, p. 11).

Nessa perspectiva, o coordenador pedagógico deverá ter a clareza de que o ato da formação docente necessita ser planejado, refletido, para que atitudes imediatistas, descontextualizadas e desgastantes sejam evitadas, além de ser criativo, concedendo à formação a possibilidade de reconfiguração da vida social tendo como princípio a tomada de decisões sociais e tomando atitudes sociais inovadoras (CHRISTOV, 2010).

André e Vieira (2010) afirmam que esse envolvimento com as questões sociais, vivendo os sucessos e insucessos próprios do processo de se relacionar com as pessoas ao conhecer as diferentes histórias de formação dos professores, o coordenador se deparará com conflitos e incertezas que o levará, muito provavelmente, a pensar e repensar o seu próprio processo de formação e o processo de formação que desenvolve na escola. Esse fazer 
transformador instigará os professores a também pensarem e repensarem suas práticas, a transformarem seu ensino a partir da reflexão sobre suas próprias histórias.

Coordenar um grupo de seres diversos e tão singulares, com histórias de vida tão diferenciadas “[...] implica articular vários pontos de vista ou atividades em direção a um objetivo comum" (SOUZA, 2010, p. 48) que, no caso, é a formação da consciência autônoma do professor remetendo-o a uma atuação livre das amarras das exigências sociais e econômicas orientadas pela lógica capitalista.

O coordenador pedagógico "[...] enquanto líder do processo educativo na escola" (SOUZA, 2010, p. 99) deverá ter a sensibilidade e a sabedoria de conduzir o grupo à constituição da sua identidade, principalmente nesse contexto tão carente de liderança pedagógica consciente.

Estou ciente de que o coordenador no seu papel formador é um agente fundamental para suscitar questões e trazer proposições que venham a impactar na prática docente, começando pela sua conscientização do seu papel formador, passando pela valorização de seus pares, pelo reconhecimento da importância do seu trabalho, culminando na reorganização do tempo da coordenação pedagógica para que seja realmente proveitoso para o planejamento, os estudos e a formação continuada docente. 


\section{O ESPAÇO/TEMPO DA COORDENAÇÃO PEDAGÓGICA E A FORMAÇÃO CONTINUADA DOCENTE: ANÁLISE DO DITO, VISTO E VIVIDO}

Com a pesquisa, busquei identificar as concepções dos interlocutores sobre escola, coordenação pedagógica e formação continuada docente. Cabe ressaltar que tais concepções expressas nas respostas dos docentes ainda são marcadas pelo campo da idealização, muito mais do que o que é observado de fato em termos práticos da valorização da formação continuada no espaço/tempo da coordenação pedagógica e do papel do coordenador pedagógico como formador.

No presente capítulo tenho o propósito de analisar a proposta de formação continuada docente desenvolvida pelos coordenadores pedagógicos locais no espaço/tempo da coordenação pedagógica e sua contribuição para a formação dos professores dos anos iniciais; analisar as influências e implicações dos aspectos históricos, sócio-políticos e culturais na formação continuada dos professores dos anos iniciais do Distrito Federal no contexto atual; analisar as concepções de formação continuada dos coordenadores locais e dos professores regentes; discutir as estratégias de formação empreendidas pelos coordenadores pedagógicos dos anos iniciais no espaço/tempo da coordenação pedagógica e, por fim, analisar as perspectivas/concepções das estratégias da formação continuada que se fazem presentes no espaço/tempo da coordenação pedagógica dos professores dos anos iniciais.

Apresento uma análise que busca atingir os objetivos traçados tendo como embasamento teórico a análise de conteúdo das falas e expressões dos sujeitos investigados, buscando abstrair dos discursos as suas determinações mais concretas, no sentido de encontrar elementos que possibilitem responder as minhas questões e de igual modo atingir os objetivos iniciais.

A partir dessa análise categorial que emergiram da pesquisa considero a totalidade do texto tendo o cuidado de utilizar os crivos da classificação e do recenseamento segundo a frequência ou a ausência de itens que trouxessem sentindo e que fossem ao encontro dos meus objetivos.

Segundo Bardin (2011, p. 42),

[...] Análise de conteúdo é um conjunto de técnicas de análise das comunicações visando obter, por procedimentos sistemáticos e objetivos de descrição do conteúdo das mensagens, indicadores (quantitativos ou não) que permitam a inferência de conhecimentos relativos às condições de produção/recepção (variáveis, inferidas) destas mensagens. 
Tendo como base o referencial teórico já apresentado, esse movimento interpretativo-dialético foi bastante significativo, pois me ajudou a classificar os elementos de significação que constituem a mensagem ora explícita, ora implícita nas expressões dos interlocutores que revelou aspectos subjacentes ao que acontece no contexto pesquisado (BARDIN, 2011).

Essa leitura dos conteúdos das comunicações não foi de modo algum uma leitura ao "pé da letra", mas acima de tudo foi uma leitura que buscou abstrair e realçar os sentidos que se encontravam em segundo plano de tudo o que foi dito, escrito e executado.

Nesse sentido, busquei apoio em Bardin (2011, p. 33) ao afirmar: "a análise de conteúdo é um conjunto de técnicas de análise das comunicações”. E, em Franco (2008, p. 19), que fortalece essa perspectiva, ao afirmar que "o ponto de partida da Análise de Conteúdo é a mensagem, seja ela verbal (oral ou escrita), gestual, silenciosa, figurativa, documental ou diretamente provocada", de modo que o nível empírico e o nível teórico sejam verificados no corpo das hipóteses e no corpo do texto.

Compreendo a análise de conteúdo como fundamental e determinante para que o presente estudo venha atingir de maneira qualitativa os objetivos propostos de revelar comportamentos e concepções presentes, ou não, nos discursos dos interlocutores.

Portanto, tornou-se essencial que eu fizesse logo de início a descrição da estrutura física das escolas e da organização do trabalho pedagógico, para em seguida, ao abordar a organização do espaço/tempo da coordenação pedagógica, pudesse recorrer às expressões dos interlocutores depreendendo daí concepções de formação continuada docente, das funções do coordenador pedagógico e de escola, para só então, em sequência, a partir das dinâmicas descritas nas expressões dos professores e das coordenadoras pedagógicas, delineando as ações de acordo com tais expressões, construir a imagem da formação continuada docente nas duas escolas.

\subsection{Evidenciando a realidade}

Partindo do pressuposto de que a pesquisa qualitativa permite um envolvimento entre pesquisador e interlocutores, uma vez que as informações a respeito do objeto de pesquisa são partilhadas, a abertura desse espaço dialógico é concretizada pela frequência do pesquisador no ambiente pesquisado e pela aproximação com todos os participantes onde naturalmente e aos poucos vai estabelecendo um clima confiável entre todos. 
Na pesquisa estavam inseridos como participantes em cada escola: os gestores, as coordenadoras pedagógicas e os professores dos anos iniciais, todos eles identificados mais adiante.

Desse modo, na busca para estabelecer e estreitar vínculos procurei, a cada encontro, uma aproximação com os envolvidos na pesquisa. Tentei estabelecer com todos uma relação dialógica para criar um ambiente de confiança e de parceria, visando possibilitar que aquele espaço/tempo já construído fosse legitimado, também, nas falas e expressões de cada um e que todos pudessem sentir-se livres para se expressar, tomando como decisão pessoal o fato de participar ou não da pesquisa. Tendo isso em vista, delinearei a seguir a construção do cenário das escolas pesquisadas.

\subsubsection{Os interlocutores}

Participar de uma pesquisa nem sempre é fácil, pois o sujeito pesquisado pode não se sentir a vontade e ter dificuldade para agir com naturalidade. Mesmo assim, tanto as diretoras como as coordenadoras pedagógicas e os professores regentes de ambas as escolas objeto da pesquisa foram receptivos, acessíveis e colaborativos.

A princípio, foram vinte e três professores e as duas coordenadoras pedagógicas que se dispuseram a participar, contudo, após a aplicação do primeiro questionário, alguns professores da UE 01 optaram por não mais participar e com a aplicação dos demais questionários, outros professores desistiram por terem encerrado seus contratos temporários.

Com o desenvolvimento das observações, senti a necessidade de integrar ao grupo de sujeitos pesquisados as duas diretoras e, na UE 02, a professora da Sala de Recursos se propôs a participar. Desse modo, ficou assim o quadro dos interlocutores da pesquisa:

Quadro 4 - Interlocutores da pesquisa

\begin{tabular}{|c|c|c|}
\hline UE 01 & Formação & Tempo de serviço na SE \\
\hline Professor & Letras Português/Inglês & 23 anos \\
\hline PR 01 & Pedagogia & 15 anos \\
\hline PR 02 & Pedagogia & 18 anos \\
\hline PR 03 & Pedagogia & 19 anos \\
\hline PR 04 & História & 15 anos \\
\hline PR 05 & Artes Plásticas & Contrato Temporário \\
\hline PR 06 & Pedagogia & Contrato Temporário \\
\hline PR 07 & Pedagogia & 1 ano \\
\hline PR 08 & Não respondeu & 11 anos \\
\hline PR 09 & Pedagogia & Contrato Temporário \\
\hline PR 10 & Pedagogia & \\
\hline PR 11 & &
\end{tabular}




\begin{tabular}{|c|c|c|}
\hline Coordenadora & Formação & Tempo de serviço na SE \\
\hline CP 01 & Pedagogia & $\begin{array}{c}15 \text { anos } \\
2 \text { anos na função de Coordenadora } \\
\text { Pedagógica }\end{array}$ \\
\hline Diretora & Formação & Tempo de serviço na $\mathrm{SE}$ \\
\hline DR 01 & Matemática e Filosofia & $\begin{array}{c}24 \text { anos } \\
06 \text { anos no cargo }\end{array}$ \\
\hline UE 02 & \multirow[t]{2}{*}{ Formação } & \multirow[t]{2}{*}{ Tempo de serviço na $\mathrm{SE}$} \\
\hline Professor & & \\
\hline PR 01 & Pedagogia & 01 ano \\
\hline PR 02 & Pedagogia & 02 anos \\
\hline PR 03 & Pedagogia & Contrato Temporário \\
\hline PR 04 & Pedagogia & 17 anos \\
\hline PR 05 & Filosofia & 11 anos \\
\hline PR 06 & Pedagogia & 05 anos \\
\hline PR 07 & Pedagogia & Contrato Temporário \\
\hline PR 08 & Pedagogia & 01 ano \\
\hline PR 09 & Pedagogia & 05 anos \\
\hline PR 10 & Pedagogia & 20 anos \\
\hline PR 11 & Pedagogia & 14 anos \\
\hline PSR & Letras & 29 anos \\
\hline Coordenadora & Formação & Tempo de serviço na SE \\
\hline $\mathrm{CP} 02$ & $\begin{array}{c}\text { Estudos Sociais - História e } \\
\text { Geografia }\end{array}$ & $\begin{array}{c}25 \text { anos } \\
15 \text { anos na função de } \\
\text { Coordenadora Pedagógica }\end{array}$ \\
\hline Diretora & Formação & Tempo de serviço na $\mathrm{SE}$ \\
\hline DR 02 & Pedagogia & $\begin{array}{c}18 \text { anos } \\
03 \text { anos no cargo }\end{array}$ \\
\hline
\end{tabular}

Fonte: Elaborado pela autora. Pesquisa de mestrado, 2015.

Desse modo, os interlocutores da pesquisa foram vinte e dois professores regentes e uma professora da sala de recursos dos anos iniciais da educação básica, duas coordenadoras pedagógicas e duas diretoras das duas unidades de ensino. A escolha destes interlocutores se deu em função dos objetivos da pesquisa.

É importante esclarecer que apesar de, em muitas escolas, os professores que assumem a função de coordenador pedagógico serem os que "sobram", não foi o caso das interlocutoras CP 01 e CP 02, ambas optaram por assumir a função e foram referendadas pelo grupo de professores. E as diretoras passaram pelo processo de eleição, no qual toda a comunidade escolar participou votando, inclusive os estudantes acima de 12 anos.

Outro critério importante para a participação na pesquisa foi o da disponibilidade e do interesse no projeto. Assim sendo, todos eles assinaram o termo de consentimento livre e esclarecido (Apêndice A) sobre os objetivos científicos da pesquisa e da segurança de terem suas identidades mantidas em sigilo.

\footnotetext{
${ }^{1}$ Expressão utilizada para designar os professores que excedem ao número de turmas da escola e deveriam ser
} devolvidos à CRE. 
Antes de iniciar a pesquisa, apresentei nas duas UE's a proposta de pesquisa aos gestores e às coordenadoras e solicitei um espaço/tempo da coordenação pedagógica coletiva para a apresentação do projeto e para convidar os professores a participarem. Realizei as apresentações nas duas escolas no momento da coordenação coletiva em ambos os turnos para todos que tiveram interesse. Só depois, iniciei o trabalho de campo.

Com essa experiência, vi que adentrar territórios alheios nem sempre é uma tarefa fácil e no decorrer das observações pude perceber que a minha presença em ambas as escolas trazia certa mudança na dinâmica dos professores. Percebi, também, que eles, de certa forma, sentiam-se desconfortáveis em ter que responder aos questionários na minha presença. Por este motivo, passei a não esperar que eles respondessem no momento da entrega, deixando-os com as coordenadoras e recebendo-os na semana seguinte. No entanto, muitos professores só se lembravam de responder o questionário na semana seguinte quando me viam na escola. Respondiam às pressas e me entregavam.

Como pesquisadora, procurei encontrar os diferentes sentidos que levavam os participantes a tomarem algumas posturas, afinal quem pode garantir sempre o que acontecerá no ambiente de pesquisa? Coloquei-me em um movimento de constante observação, reflexão, construção e reconstrução do processo de formação como pesquisadora e busquei meios de fortalecer o processo comunicativo entre mim e os interlocutores. Busquei analisar as ações e reações de cada um deles para alcançar a compreensão de suas atuações no ambiente escolar.

Diante desse fato, descobri que para me constituir pesquisadora, eu deveria me destituir de quaisquer formas de melindres e de orgulho, pois, considerando os desafios que se impunham, compreendi com clareza que "na pesquisa qualitativa [...], o grupo não é uma soma de indivíduos, mas um espaço de reflexão coletiva" (GONZÁLEZ REY, 2005, p. 86), no qual transparece as individualidades e se constitui a coletividade. Logo, eu estaria lidando com um universo singular.

Assim, tomei ciência de que nesse processo investigativo, são as situações vivenciadas que vão propiciando a tessitura da pesquisa e vão revelando aos poucos, as concepções que se interrelacionam e são externalizadas por meio das falas e das atitudes dos sujeitos pesquisados. Compreendi que o papel de cada um nesse processo, inclusive o meu, se constrói por muitas idas, vindas e muitos olhares cuidadosos a respeito do que se deseja descobrir. 


\subsubsection{Encontros e desencontros}

A primeira visita que fiz às escolas foi no dia 02 de fevereiro de 2014 para conversar com os gestores e com as coordenadoras, falar sobre a pesquisa e pedir um tempo no espaço da coordenação coletiva para apresentar o projeto de trabalho. Acredito ser importante pontuar que nesse dia, encontrei a coordenadora da UE $01 \mathrm{em}$ sala de aula substituindo uma professora, entretanto, apesar disso, esta me recebeu prontamente e se colocou à disposição em organizar o grupo para participar do momento por mim proposto.

O segundo encontro, em função de algumas demandas da CRE, só foi agendado para o dia 19 de fevereiro de 2014, data na qual apresentei o projeto nos dois turnos para todos os professores das duas UE's que se interessaram em conhecê-lo.

A partir daí, os encontros foram semanais, sempre nas quartas-feiras. Na maioria das vezes compareci em turnos alternados, ou seja, se em uma quarta feira eu ia pela manhã para uma escola, na quarta feira seguinte eu ia no turno vespertino. Mas, também, houve dias nos quais eu compareci em ambos os turnos nas duas escolas, dependendo da necessidade que senti em participar dos momentos de coordenação e de formação. Assim, as visitas foram realizadas de fevereiro a julho de 2014, porém, com uma pausa em junho em função do recesso por causa da Copa do Mundo realizada no Brasil.

Houve receptividade por parte da direção e das coordenadoras pedagógicas imediatamente após eu explicitar os objetivos da pesquisa. Nesse mesmo dia acertamos que eu teria um tempo da coordenação pedagógica coletiva para apresentar a proposta ao grupo de professores, coordenadores e gestores.

$\mathrm{Na}$ quarta feira, 19 de fevereiro, apresentei o projeto aos grupos, momento em que travamos um diálogo bastante produtivo. Senti a receptividade dos professores regentes diante de vários questionamentos e preocupações, o que tornou o momento muito interessante. $\mathrm{O}$ grupo se posicionou quanto à importância da pesquisa em função do tema proposto para ser investigado que consideravam atual e carente de reflexões.

Iniciei efetivamente a partir daquele momento um processo ininterrupto de idas e vindas à escola. Após a Copa do Mundo retornei às UE's procurando dirimir algumas dúvidas a respeito da formação continuada docente no espaço/tempo da coordenação pedagógica.

A cada encontro tentei maior aproximação e envolvimento com o grupo tendo além do intuito de conhecer a dinâmica organizacional da escola, o cuidado de interferir o 
mínimo possível na rotina das unidades escolares nos momentos de observação e participação formal.

Como mencionada anteriormente, no início procurei participar nos turnos matutino e vespertino. Depois alternei a observação nos turnos buscando fortalecer o processo de investigação e participar dos momentos de formação continuada nas duas escolas, com os quatro grupos de professores regentes das duas unidades escolares. Com essa organização, consegui alcançar as condições necessárias para o desenvolvimento da pesquisa.

No período da minha observação da coordenação pedagógica coletiva na UE 01, ou seja, nos 12 momentos nos quais estive presente no espaço/tempo da coordenação pedagógica das quartas-feiras, não tive a oportunidade de participar de nenhum momento coletivo com todos os segmentos e nem de formação continuada, o que indica que nela, ainda não há uma clara organização do trabalho pedagógico e não se tem uma dinâmica consolidada de formação continuada docente.

Considerando as especificidades de cada escola, vivenciei uma dinâmica bastante diferente na UE 02. Todas as quartas em que realizei as observações, com exceção de duas, dia 12 de março que os professores do BIA haviam sido convocados para um encontro do PNAIC e dia 07 de maio que houve paralisação geral convocada pelo CNE, encontrei os professores reunidos na sala de leitura/educação integral em momento de formação continuada e planejamento pedagógico com uma pauta, um texto base para discussão, em geral um artigo científico e o currículo para o planejamento da quinzena.

Também houve momentos em que foram convidados professores de outras unidades escolares com experiência em psicomotricidade e matemática para compartilharem experiências com as professoras da UE 02. E momentos ainda, que as professoras se deslocaram para um pólo da EAPE que há na cidade para participarem de formação matemática organizado em parceria entre a CP 02 e duas tutoras do PNAIC.

Apresentando condições diferenciadas, mas problemas semelhantes, as duas coordenadoras das UE's conduziam a organização do espaço/tempo da coordenação pedagógica e a formação continuada docente de forma peculiar.

Acredito que esse agir diferenciado seja determinado pela constituição da própria coordenadora pedagógica na qualidade de sujeito, assumindo cada vez uma postura de liderança dentro dos diferentes espaços de suas experiências profissional e social, gerando novas zonas de significação para a organização do espaço no qual atua. 
A CP 01 está na coordenação pedagógica há dois anos, mas não teve formação específica para exercer essa função e afirma que,

\begin{abstract}
A Secretaria de Educação deveria realmente dar algum curso, alguma formação voltada para a coordenação pedagógica sim. Até por que, quando você entra numa função de coordenador você é professor, você saiu de uma sala de aula, então você está num ambiente que não conhece ainda. Sabe do pedagógico que ele está, mas o funcionamento, a engrenagem da escola funcionando, a gente não tem isso, a gente aprende com a prática, não é? Mas eu acho que sim, é muito válido. (Entrevista).
\end{abstract}

E a CP 02 apesar de exercer a função de coordenadora pedagógica há 15 anos, também não teve formação específica em coordenação pedagógica. A respeito dessa falta de formação afirma:

\footnotetext{
Assim que fui coordenadora, tive a oportunidade de trabalhar com um grupo que já constituía coordenador. Nesses 15 anos como coordenadora só trabalhei com equipes altamente pedagógicas [...] Então, isso me ajudou muito. (Entrevista).
}

Essa necessidade formativa se articula com o direito estando prevista na legislação, Art. 64 da LDB, e implica em os Estados terem o dever de propiciar além da formação inicial, a formação continuada aos docentes e que o direito a esta "formação não pode fugir de seu compromisso básico com a docência cujo processo formativo não dispensa nem o ato investigativo da própria práxis e nem o contato com a produção intelectual qualificada da área” (CURY, 2000, p. 2).

De fato, durante muito tempo não houve formação específica para os professores que iriam atuar como coordenadores pedagógicos, seja no nível local, intermediário ou central. Essa formação específica iniciou a partir de 2012, como dito anteriormente ao relatar sobre minha própria experiência, com o curso de especialização lato sensu em Coordenação Pedagógica oferecido para os coordenadores da rede em efetivo exercício, por meio do convênio firmado entre a Secretaria de Estado de Educação do Distrito Federal - SEEDF e a Reitoria da Universidade de Brasília - UnB, via Centro de Estudos Avançados Multidisciplinares - CEAM, pela Coordenação de Formação Continuada - CFORM.

Pela minha própria experiência posso afirmar que a fundamentação teórica dessa especialização e organização didático-pedagógica, encaminha os estudos e as reflexões na perspectiva de romper com muitos paradigmas da educação reprodutivista por meio do fluxo da teorização crítica, favorecendo a transmutação de questões que hoje estão no cerne da função de coordenar para transcender a cisão entre teoria e prática. 
As discussões suscitadas, os textos lidos e os trabalhos realizados dão de fato condições ao coordenador pedagógico de refletir sobre o seu papel, como organizar o trabalho pedagógico e a formação continuada dos professores com maior segurança, de forma que o trabalho tenha objetivos mais amplos do que apenas refletir sobre a prática docente e seja encaminhado colaborativamente para atinja os seus objetivos.

No segundo semestre de 2014 iniciou a segunda turma do citado curso. A CP 02 está cursando essa especialização e participando do processo seletivo para o mestrado acadêmico também da UnB.

Observando a dinâmica das escolas e a atuação das coordenadoras pedagógicas, identifiquei a necessidade delas se dedicarem mais especificamente às atividades pedagógicas e à formação continuada do professor, mas para isso, o coordenador pedagógico também precisa de formação continuada, pois sendo sujeito formador, precisa se atualizar constantemente para exercer de forma competente sua função.

Como visto, ambas apontam a falta de formação específica como fator que dificulta a atuação do coordenador pedagógico. Desse modo, cada uma vai, a seu modo, em encontros e desencontros, se constituindo coordenadora e desenvolvendo habilidades para superar as dificuldades que surgem no fazer pedagógico.

\subsubsection{A estrutura física e o reflexo na organização do trabalho pedagógico}

Essa diferença na estrutura física e no perfil das unidades escolares fez com que emergissem diferenças de atuação das equipes gestoras, diferença do apoio ao desenvolvimento do trabalho pedagógico em ambas e, consequentemente, diferença nas ações das coordenadoras pedagógicas.

A investigação sobre a formação continuada docente no espaço/tempo da coordenação pedagógica foi desenvolvida em duas escolas públicas rurais, escolas do campo ${ }^{2}$, com perfis bastante diferentes. Enquanto uma escola que chamarei aqui de UE 02 atende apenas alunos de Educação Infantil e Anos Iniciais do Ensino Fundamental, a outra que denominarei de UE 01, atende Educação Infantil, Anos Iniciais, Anos Finais, Ensino Médio Regular e os três segmentos da EJA, funcionando nos três turnos.

A UE 01 está situada na área de proteção ambiental que margeia o Parque Nacional de Brasília, em Área de Proteção Ambiental. Com a estruturação do Núcleo Rural

\footnotetext{
${ }^{2}$ Denominação atual das escolas de zona rural aqui no Distrito Federal.
} 
no fim da década de 1980, surgiu a demanda educacional da região e em setembro de 1991 a Associação local cedeu duas salas para que servissem de "escola", com o apoio do poder público que destinou recursos financeiros e humanos para o atendimento de tal demanda.

Todavia, o rápido crescimento do Núcleo Rural entre 1990 e 1998 repercutiu nas necessidades de educação do local e mesmo a Associação local cedendo mais duas salas para aumentar a "escola", o prédio já não comportava a grande quantidade de alunos matriculados e mais outro tanto de trabalhadores e filhos de trabalhadores que buscavam por vaga.

Diante desse cenário, a comunidade reivindicou a construção de um prédio específico para a escola e em 15 de agosto de 1998, a UE 01 foi entregue e começou a atender o primeiro grau, hoje ensino fundamental. Com o progressivo crescimento da comunidade local, consequentemente houve um aumento da demanda escolar e em 1999 a escola, que até então só atendia o primeiro grau, passou a atender também segundo grau e a pré-escola, hoje denominados respectivamente de ensino médio e educação infantil. Apesar dessa ampliação no atendimento da comunidade, só em 2012 a escola passou a ser denominada Centro Educacional.

Hoje, a UE 01 atende mais de 1500 alunos nos três turnos. 90\% da sua clientela é composta pelos trabalhadores rurais e sua parentela em geral que vive e trabalha nas chácaras daquele núcleo e outros $10 \%$ constituída por filhos dos pequenos proprietários do comércio local e dos proprietários rurais. Desse total de alunos mais de 320 são dos anos iniciais atendidos nos turnos matutino e vespertino, contando com 13 professores e uma coordenadora que atendem essa etapa.

Nessa UE há uma grande rotatividade dos alunos em função da grande mobilidade dos trabalhadores nas propriedades, sendo esta, muitas vezes, motivo da evasão de alunos.

Outra peculiaridade, é que, por ser uma área rural de grande extensão, muitos alunos tem que caminhar grandes distâncias mesmo tendo o transporte escolar, pois esse transporte só percorre a pista principal e da "cabeceira da pista" até o final das ruas pode-se percorrer distâncias de mais de $4 \mathrm{~km}$. Tal realidade reflete no atraso de muitos alunos, fato que leva a UE a flexibilizar os horários e repensar sua dinâmica pedagógica. Um dos desafios explicitado pela UE no seu PPP é despertar o interesse e trazer a comunidade à participação mais efetiva das atividades propostas, assim como fortalecer o acompanhamento dos responsáveis na vida escolar dos alunos ${ }^{3}$.

\footnotetext{
${ }^{3}$ Informações retiradas do Projeto Político Pedagógico da unidade de ensino pesquisada.
} 
Em relação à estrutura física, ela possui salas de secretaria, mecanografia, direção, vice-direção/coordenação onde ficam juntos o vice-diretor, supervisor pedagógico e os coordenadores pedagógicos de cada etapa. Há, também, uma sala para a orientação educacional e uma para a equipe de apoio à aprendizagem.

A sala dos professores é ampla, comportando escaninhos para todos os professores, armário para guardar o material de educação física, três mesas grandes, TV de LED e uma cozinha interligada com fogão, geladeira, microondas, filtro elétrico, mesa e cadeiras.

A UE conta, ainda, com uma biblioteca, um laboratório de informática, uma sala de vídeo ampla com cadeiras acolchoadas, um data show e um bom sistema de som. Segundo a coordenadora e a diretora, é nesses espaços que eles se reúnem para realizar a formação continuada docente nos dias de quarta feira.

A escola conta ainda com 15 salas de aula, mas apenas 5 salas são destinadas às turmas de anos iniciais. Elas ficam localizadas no último pavilhão e é nesse espaço, isolado com cones, entre os dois pavilhões, que acontece o recreio dos alunos sob a supervisão da coordenadora pedagógica dos anos iniciais. Há, também, uma quadra sem cobertura para a prática esportiva, um pátio interno que também serve de refeitório, banheiros para alunos e banheiros para professores.

No que diz respeito à conservação do ambiente, há servidores terceirizados, isto é, são funcionários de uma empresa particular contratada pela SEEDF para prestar o serviço de manutenção e de limpeza. Os alunos também colaboram com a conservação do prédio que apresenta boa aparência tendo as paredes com a pintura bem conservada, o piso sempre limpo e encerado, o que chama a atenção pela quantidade de alunos atendidos pela UE.

A UE 2 está localizada próxima à uma vila. Sua construção também resultou da mobilização da comunidade local que sentia a dificuldade de ter que caminhar cerca de $6 \mathrm{~km}$ para levar os filhos à escola mais próxima. Com a doação da área feita por uma moradora do local, a escola foi inaugurada em outubro de 1998.

Nos primeiros anos de funcionamento a unidade de ensino atendia em média 50 alunos e funcionava apenas em um turno com turmas multisseriadas. Com o crescimento da comunidade em derredor, houve a necessidade de ampliação do atendimento para os dois turnos e em 2008, por atender critérios estabelecidos pela SEEDF, implantou o projeto de educação integral. 
Atualmente a escola atende 245 alunos de educação infantil ao $5^{\circ}$ ano e pela distância das inúmeras comunidades que a escola presta atendimento é contemplada com o transporte escolar oferecido pelo governo. Talvez por esse motivo não sofra muito com a evasão, apesar de ter um considerável número de transferências pela mobilidade de algumas famílias ${ }^{4}$.

Na escola há cinco salas de aula, sala de secretaria com uma pia, filtro e um armário para guardar utensílios de cozinha, um pequeno depósito ligado à secretaria onde foi colocado um duplicador e tem servido de mecanografia. Há a sala da direção que comporta a diretora, o vice- diretor e a coordenadora pedagógica.

Há, também, uma sala de leitura onde são realizadas algumas das atividades da educação integral. Entretanto, nas quartas feiras o espaço é utilizado para a formação dos professores por ser mais espaçosa, arejada e confortável. Há banheiros para alunos e alunas, banheiros para professoras, mas os homens que trabalham na escola utilizam o banheiro dos alunos.

E por trás da escola foi recém construído um espaço dividido em depósito e sala para o atendimento pedagógico, uma outra salinha (sala de recursos) onde são atendidos os alunos diagnosticados com dificuldade de aprendizagem ou alguma outra necessidade especial e uma cozinha onde são feitas as refeições dos funcionários terceirizados.

A sala dos professores é pequena, mas nela há escaninhos para todos os professores guardarem materiais e escaninhos para receberem atividades xerocopiadas, uma mesa grande, cadeiras, uma TV, uma geladeira e um computador com impressora. Quando os professores estão lá, não há como circular por ela.

Tem um pátio coberto onde os alunos são recebidos na entrada, e um minicampo de futebol em uma pequena área lateral cimentada, porém não há espaço físico para a construção de uma quadra poliesportiva apesar de a escola já ter ganhado do governo a cobertura da quadra.

A escola conta com quatro servidores terceirizados, que trabalham na conservação e limpeza, segurança 24 horas feita por uma empresa de vigilância também contratada para prestar o serviço, além de duas cozinheiras. Curiosidade: uma das cozinheiras é a dona da área em derredor da escola. Foi ela quem fez a doação do terreno para a construção da UE e trabalha como cozinheira na escola desde que ela foi inaugurada.

\footnotetext{
${ }^{4}$ Informações retiradas do Projeto Político Pedagógico da unidade de ensino pesquisada.
} 
Como na UE 01, a UE 02 no que diz respeito à conservação do ambiente, a escola é bem cuidada por parte dos servidores e dos alunos para a conservação do prédio. Ela que é comparada por alguns servidores a escolas particulares pela boa aparência, possui bancos plásticos em forma de lápis colorido no pátio, paredes e murais sempre enfeitados e no piso colorido é desenhado amarelinha e caracol nas áreas de cimento e a parte de gratina é diariamente lavada e encerada.

Ambas tem a mesma peculiaridade, pois sendo escolas rurais um pouco distantes da cidade, os professores passam o dia e os servidores terceirizados são da própria comunidade.

Essa limitação de espaço físico como fator relevante, aparece de forma mais frequente nas falas dos interlocutores da UE 01, mas segundo eles, há tentativas de superar essa dificuldade tanto por parte da direção, da coordenação pedagógica e dos professores na busca de alternativas para a realização da formação continuada utilizando os espaços possíveis da escola.

Percebi que a questão do espaço físico nas duas UE's não é o ideal para atender as necessidades tanto dos alunos quanto dos professores e para alguns dos interlocutores, essa falta de espaço se configura como um fator que dificulta o desenvolvimento do trabalho pedagógico.

Diante dessa realidade, compreendo a importância do planejamento do trabalho pedagógico que deve ser organizado para que possa possibilitar a superação dessas limitações que se impõem ao desenvolvimento do trabalho docente (SOUZA; PLACCO, 2013).

Considerando essas limitações, tanto professores regentes como a coordenadora pedagógica falam da contradição do que deve ser e do que acontece de fato nas escolas públicas do Distrito Federal. Afirmam que tais contradições já começam pela própria inadequação da estrutura física das escolas que não apresentam espaços apropriados para que o trabalho pedagógico seja desenvolvido de maneira que venha a atender questões que inclusive são trazidas pelo próprio currículo para o desenvolvimento da aprendizagem dos alunos.

Para os interlocutores da UE 01 uma melhor estrutura física poderia favorecer tanto os momentos de formação continuada dos docentes que nela trabalham quanto a atuação pedagógica dos professores.

Na UE 01, segundo a DR 01 para a formação no espaço tempo da coordenação pedagógica “falta sala apropriada para coordenação" (Questão 07), para a CP 01 isto é um 
grande problema: “as escolas superlotadas onde os espaços são disputados por todos os segmentos" (1 Questionário aberto, Questão 10) e segundo a PR 01, "enquanto o poder público, responsável pela educação no Brasil, não aprender que as teorias dos pensadores que nunca entraram em sala de aula lotada da escola pública, não resultam em ensino de qualidade, nada mudará" ( $3^{\circ}$ Questionário, expressões livres).

Transitando nos espaços pesquisados, identifiquei que esse problema de falta de espaço físico não é problema de uma das unidades escolares, é uma característica das duas. Em ambas, não há um espaço físico determinado à coordenação pedagógica e nas duas buscam-se adaptações desses espaços.

Na UE 01, segundo os interlocutores, a formação continuada docente acontece em vários espaços, de acordo com a disponibilidade. Podem ser utilizados os espaços da biblioteca, da sala de vídeo ou do laboratório de informática, além da sala dos professores.

Na UE 02, as coordenações coletivas e a formação continuada das professoras acontecem na sala de leitura que também é usada como espaço para a educação integral que não atende os alunos nas quartas feiras, em função da utilização do espaço pelos professores.

Apesar dessa falta de espaço específico para se realizar as reuniões coletivas e a formação continuada no espaço escolar, apenas os interlocutores da UE 01 declararam suas insatisfações em relação à falta de um espaço específico para que eles possam se reunir, planejar, trocar experiências, realizar a formação, como sendo um empecilho.

Alguns deles, de uma forma ou de outra, fizeram alguma observação sobre isso em algum momento da pesquisa. Vejamos:

O nosso espaço de coordenação individual normalmente é feito na sala dos professores uma vez que não existe uma sala de coordenação e quando temos que fazer a coordenação coletiva, na quarta feira, no primeiro momento da coordenação ficamos todos os professores de todos os segmentos na sala de vídeo ou de informática (e quando estamos nessas salas elas não podem ser usadas pelos alunos das escolas). Depois dividimos os grupos: ensino médio, ensino fundamental séries finais e ensino fundamental séries iniciais para estudos de acordo com cada necessidade. ( $1^{\circ}$ Questionário aberto, Questão 02, PR 01, UE 01).

Acho que deveria ter pelo menos três salas de coordenação na nossa escola, aonde cada sala deveria ser usada por cada segmento da escola (ensino médio, séries finais e séries iniciais) para que cada segmento tivesse um local para mais estudo dos professores. ( $1^{\circ}$ Questionário aberto, Questão 03, PR 01, UE 01).

O tempo corresponde à necessidade, porém o espaço deixa a desejar visto que atende a vários grupos, com objetivos distintos no mesmo período na mesma hora. Além disso, o espaço não dispõe de ferramentas necessárias, indispensáveis para concretização das ações. ( $1^{\circ}$ Questionário aberto, Questão 02, PR 02, UE 01). 
O espaço físico poderia ser maior para evitar tanto barulho. ( $1^{\circ}$ Questionário aberto, Questão 03, PR 03, UE 01).

[...] a escola atende as séries iniciais e finais do ensino fundamental e ensino médio no diurno, mas não conta com espaço físico separado para cada uma dessas etapas, o que traz alguns contratempos, tais como: excesso de pessoas em um mesmo ambiente, dificultando a concentração e mesmo o uso do mobiliário. ( $1^{\circ}$ Questionário aberto, Questão 02, PR 10, UE 01).

Precisamos de espaço separado para as coordenações de cada etapa [...]. ( $1^{\circ}$ Questionário aberto, Questão 03, PR 10, UE 01).

A partir das expressões dos sujeitos da UE 01, compreendi que a falta de um espaço específico e adequado para a coordenação coletiva e a formação continuada na escola gera insatisfação no grupo e, segundo eles, "prejuízo" ao trabalho pedagógico.

Como foi dito pela PR 01, sem salas específicas para o momento das coordenações pedagógicas, os professores precisam utilizar espaços destinados ao uso dos alunos (biblioteca, sala de vídeo, laboratório de informática), nem sempre isso é possível e a dificuldade de realizarem os momentos de estudos por causa do barulho quando professores de todas as etapas estão reunidos no mesmo ambiente, o que acaba gerando desmotivação no grupo. Logo, os prejuízos relatados pelos professores são de ordem pedagógica e emocional.

Nesse sentido, uma das professoras quando questionada se em função da falta de espaço e da necessidade da realização da formação continuada na escola ela sugeria alternativas para que essa formação de fato ocorresse, afirma: "Não. Acho que por não haver espaço físico isso acaba desmotivando qualquer coisa que precisa acontecer no espaço da escola" (PR 01, UE 01, Questão 5 do $3^{\circ}$ Questionário aberto).

Como é possível observar, as professoras citadas compreendem que a escola é um espaço precipuamente educativo, mas asseguram que a falta de espaço adequado para os momentos de coordenação, incluindo a formação continuada, remetem à desvalorização do papel formador da escola, inclusive por parte do poder público (PR 01, UE 01, $3^{\circ}$ Questionário aberto, Livre Expressão).

A coordenadora da UE 01 denominada de CP 01, por exemplo, ao se pronunciar a respeito de como ela espera que seja a formação continuada no espaço/tempo da coordenação pedagógica na escola em que atua diz: “Ah! A gente trabalha assim, procurando alcançar objetivos. [...] tem coisas que a gente não consegue por conta do espaço restrito [...]”.

Fica claro que ela sente de alguma forma quando procura atingir objetivos, mas não consegue, que seu trabalho fica prejudicado em função da falta de um espaço físico 
adequado, pois avalia que apesar de ter objetivos, o trabalho poderia ser melhor desenvolvido, mas é dificultado por causa do espaço físico restrito.

Para, Didonet (2000) o espaço da escola não é apenas um espaço que abriga alunos, livros, professores, mas é um lugar de aprendizagem, local onde há uma docência que se desenvolve com a dinâmica social, gerando ideias, sentimentos, busca pelo conhecimento. Nesse espaço além de ser necessário ter uma estrutura física que atenda às necessidades da comunidade escolar, deve ser confortável, alegre e aprazível.

Em resumo, a estrutura física da escola deve possibilitar atingir os objetivos de ensino e de aprendizagem, além de ser e estar organizada de forma que favoreça a participação de todos, alunos e professores, nos momentos coletivos, determinando as mudanças e gerando a riqueza necessária ao trabalho pedagógico e ainda, favorecer a crítica inclusive desse próprio espaço e suas possíveis reorganizações.

É interessante pensar que todo trabalho pedagógico, inclusive o trabalho de formação continuada desenvolvido na escola enfrenta dificuldades em decorrência da estrutura física e, às vezes, essas dificuldades se constituem como barreiras que impedem o desenvolvimento desse trabalho.

No caso da UE 01, como visto, não é diferente e o espaço físico tem se constituído para eles, em um obstáculo para o desenvolvimento da formação continuada docente dentro da escola, apesar das adaptações e organização da utilização desses espaços.

Os professores explicitam prejuízos tanto na atuação com os alunos quando precisam de espaço para realizar jogos, brincadeiras e momentos de psicomotricidade, quanto nos momentos das coordenações quando há a “disputa pelos espaços” (CP 01, $1^{\circ}$ Questionário aberto, Questão 10), dificultando os momentos de reuniões e de formação.

Como visto anteriormente, essa falta de espaço físico adequado para os momentos de formação tem gerado no grupo da UE 01 o sentimento de desvalorização da educação por parte do governo e, ainda, segundo os interlocutores, tal fator tem sido um limitador do potencial do grupo e da finalidade social da escola. Mas que função seria essa?

De acordo com os interlocutores: "Adequar o indivíduo ao meio social e formar atitudes [...] (PR 01, UE 01, $3^{\circ}$ Questionário aberto, Questão 04); “[...] possibilitar melhora gradativa na qualidade de vida de uma comunidade" (PR 03, UE 01, $3^{\circ}$ Questionário aberto, Questão 04); “[...] formar o cidadão em si”, (PR 04, UE 02, $3^{\circ}$ Questionário aberto, Questão 04); “[...] educar, nortear, aprimorar, conscientizar e formar o cidadão”, (PR 07, UE 02, $3^{\circ}$ Questionário aberto, Questão 04); “[...] complementar a função da família em termos sociais e 
preparar o indivíduo em todas as áreas do conhecimento" (PR 02, UE 02, $3^{\circ}$ Questionário aberto, Questão 04); “[...] articular o intercâmbio entre a sociedade e a vida escolar” (PR 11, UE 02, $3^{\circ}$ Questionário aberto, Questão 04); “desenvolver habilidades para inserção na sociedade" (PR 01, UE 02, $3^{\circ}$ Questionário aberto, Questão 04).

Aqui, temos indícios da racionalidade que rege a prática docente tanto na UE 01, como na UE 02, pois tais expressões pressupõem uma convalidação das determinações dominantes que pretendem adaptar os indivíduos às leis da sociedade capitalista e não de transcendê-las. Sob a égide de atender às exigências do mundo moderno, a escola vem organizando o trabalho pedagógico para minimizar as mazelas do sistema e não no sentido de superá-las definitivamente.

A respeito do esvaziamento da função da escola, me reporto novamente ao fenômeno da hipertrofia da escola (Saviani, 1994), no qual constato que se ampliou o acesso da população à escola, mas esqueceu-se de ampliar seus espaços físicos. Tal fato tem gerado salas cheias e poucos espaços inclusive para que os professores se reúnam para formação e planejamento da organização do trabalho pedagógico. Sobre essa hipertrofia é possível afirmar, ainda, que ela vem sendo expandida tanto vertical como horizontalmente, ou seja, ampliam-se os anos de escolaridade e o número de horas/permanência na escola, contudo, não são ampliados os espaços físicos.

Diante desse fenômeno, segundo Saviani, "a escola tem que absorver todas as funções educativas que antes eram desenvolvidas fora da escola, já que hoje há uma tendência a esperar que as mesmas sejam desenvolvidas dentro da escola” (SAVIANI, 1994, p. 152). Essa questão tem sido motivo de preocupação dos professores, pois a função educativa que antes era responsabilidade da família do estudante passa a ser cobrada como responsabilidade da escola.

De fato, segundo alguns interlocutores, a escola, no seu interior, tem assumido encargos que extrapolam aquilo que é especificamente pedagógico, como é possível verificar na fala do PR 09 da UE 01 e da PR 08 da UE 02 respectivamente: “[...] na atualidade vejo a escola sendo cobrada para assumir além do seu papel, o papel de família numa concepção assistencialista que retira a responsabilidade dos pais"; "a função da escola hoje está distorcida, o menino vem pra jogar bola, fazer capoeira, pintar e bordar, e nós professores temos que dar conta de tudo. Foi-se o tempo que a escola servia para ensinar".

Contraditória e concomitantemente com esse fenômeno vem a secundarização da escola com o discurso de que a "[...] educação escolar não é a única forma de educação e 
sequer a principal, [...] educa-se através dos clubes, do esporte [...] através do trabalho, através da convivialidade do relacionamento informal das pessoas entre si” (SAVIANI, 1994, p. 153). Como entender essa contradição? Como pode ao mesmo tempo a escola ser hipertrofiada e desvalorizada?

Compreendendo a lógica capitalista, ficam claros os motivos, pois considerando que nessa lógica uma classe se fortalece na exploração de outra classe, é natural que à classe dominada o acesso ao saber, à cultura letrada, ao domínio dos números, dos elementos necessários para conhecer cientificamente a realidade lhes será dado em pequenas doses. Nem tanto para que não passe a deter os meios de produção, mas nem tão pouco para que não saiba lidar com esses mesmos meios de produção.

Nessa trama, é indispensável afirmar que esse fenômeno explicita preocupações de ordem capitalista. Uma concepção estreitamente atrelada à ordem da reestruturação e reprodução do capital, alinhada à racionalidade produtiva e não de produção de conhecimento científico, negando o conhecimento em sua totalidade.

Como afirmei anteriormente, é nítido o esvaziamento da função da escola e segundo Saviani (2012), justamente por ser tão óbvia essa função, é que ela tem sido esquecida, negligenciada. Contudo a partir da formação continuada docente no local de trabalho valorizando a apropriação do conhecimento metódico, sistematizado, organizando o trabalho pedagógico de forma que o principal seja posto antes do secundário será possível o desenvolvimento de uma cultura de reflexão e de crítica do que está sendo invertido pelo ideal dominante.

Para tanto, o coordenador deverá de forma consciente buscar desenvolver sua competência técnica, a sua profissionalidade, consciente da sua responsabilidade ética e de seu compromisso político para de modo intencional e sistematizado, vir a produzir novos conhecimentos a serem compartilhados com seus pares, em especial nos momentos de formação no espaço/tempo da coordenação pedagógica.

A CP 01 reconhece a importância do espaço/tempo da coordenação pedagógica, mas lamenta que a estrutura física da UE 01 não favoreça o desenvolvimento adequado do trabalho pedagógico:

A coordenação pedagógica é um espaço de transformação na escola. Através dela podemos rever e reavaliar nossos sucessos e insucessos. O que me deixa desgostosa é o fato da falta de infraestrutura das escolas, escolas superlotadas onde os espaços são disputados por todos os segmentos! Alunos de seis anos de idade misturados numa mesma escola com alunos do ensino médio. Fica muito mais difícil. $\left(2^{\circ}\right.$ Questionário Aberto, Questão 10). 
Segundo Souza e Placco (2010), são as demandas da escola que devem conduzir a elaboração do planejamento de formação e as estratégias que levarão o coletivo a superar as dificuldades que se impõem ao trabalho formativo na escola e isso implica levar o problema para o grupo, ou evidenciá-lo como sendo de fato um limitador das ações formadoras e lançar o desafio de superá-los.

No entanto, segundo as autoras, é necessário realizar um diagnóstico claro, refletido e discutido abertamente com o grupo para que seja possível pensar nas alternativas possíveis à superação dessa problemática e encontrar soluções que venham a desencadear as transformações necessárias para que o trabalho coletivo e a formação continuada docente tenham seus espaços garantidos.

Acredito que se a CP 01 pretende realizar na escola um trabalho de formação continuada que de fato ofereça suporte ao professor, auxiliando-o, por exemplo, na estruturação do Projeto Político Pedagógico, deverá criar estratégias pedagógicas que saiam do nível de reprodutividade de ação preconizado pela lógica capitalista no tempo conquistado pelos professores.

Há de se buscar alternativas para superar o desânimo citado pela PR 01 sobre a falta de espaço físico adequado possibilitando que a reunião coletiva e os momentos de formação e de reflexão das questões que fundamentam as ações docentes sejam efetivamente realizados na perspectiva de "fortalecer o desenvolvimento de atitudes de cooperação, solidariedade pela descoberta do outro para consolidar um coletivo profissional autônomo e construtor de saberes e valores próprios" (VEIGA; QUIXADÁ VIANA, 2012, p. 21).

Vi através das observações e expressões dos interlocutores da UE 01 certo ceticismo em se pensar alternativas para os problemas das limitações físicas. Acredito que tal postura tem se refletido na forma como o trabalho pedagógico está sendo concebido e desenvolvido e pode inclusive, impedir o alcance de novos avanços educativos naquele espaço.

Diante da realidade vivida, é compreensível que o olhar pela lente da criticidade mostra que as instituições educacionais estão postas a serviço de uma hegemonia que precisa desarticular quaisquer "possibilidades de manifestações próprias da classe subalterna" (CURY, 1985, p. 94). Sendo assim, é natural nessa lógica, que também os espaços físicos se constituam como limitadores da plena manifestação das classes menos favorecidas. 
Destarte, é importante que essa problemática da falta de um espaço específico seja levada em pauta para que todos os professores reflitam a respeito, compreendam que é um problema que não pode paralisá-los, pois essa paralisia impacta negativamente na articulação dos processos pedagógicos, na formação continuada como possibilidade de transformação de concepções e práticas e, consequentemente, na possibilidade de melhoria das condições de trabalho e da própria condição de sujeito nos ambientes em que eles interagem.

Na UE 02, a falta de espaço também foi citada por algumas professoras regentes, mas não como um problema determinante para o bom desenvolvimento do trabalho pedagógico. Elas deram maior ênfase no tempo da coordenação que na opinião delas, é sempre muito proveitoso, como é possível identificar nas falas a seguir:

\footnotetext{
O espaço físico é restrito [...], mas o tempo de coordenação na escola que é importante para o planejamento coletivo aqui acontece realmente. (UE 02, PR 08, Questão 2 do $1^{\circ}$ Questionário aberto).

O tempo é utilizado de maneira otimizada, necessitando de mais espaço físico. (UE 02, PR 02, Questão 2 do $1^{\circ}$ Questionário aberto).

$\mathrm{Na}$ escola que trabalho, o espaço físico tanto como o momento de coordenar a meu ver, é produtivo e adequado às necessidades. (UE 02, PR 07, Questão 2 do $1^{\circ}$ Questionário aberto).

Acho que é muito bem aproveitado e funciona sempre. (UE 02, PR 09, Questão 2 do $1^{\circ}$ Questionário aberto).
}

Em uma atitude provocativa e buscando compreender o que motiva a realização do trabalho pedagógico e de formação continuada, insisti em abordar a respeito da "falta de espaço" (Questão 05 do $3^{\circ}$ Questionário) para a realização dos momentos de formação continuada e se os professores regentes diante dessa limitação pensavam ou propunham alternativas para que essa formação de fato acontecesse.

Na UE 01, apenas duas professoras regentes e a coordenadora pedagógica responderam. Uma disse que "não" propunha (UE 01, PR 01, Questão 5 do $3^{\circ}$ Questionário aberto) e a outra deu apenas alternativas à dinâmica formativa em si, propondo "palestras $e$ eventos destinados à formação docente para a melhoria da prática pedagógica” (UE 01, PR 03, Questão 5 do $3^{\circ}$ Questionário aberto).

$\mathrm{Na}$ UE 02, as professoras regentes que falaram da limitação do espaço físico fizeram proposições: 
Sim, pois os objetivos traçados por nós só serão alcançados através dessas 'alternativas', muitas vezes sugeridas por nós. (UE 02, PR 02, Questão 5 do $3^{\circ}$ Questionário aberto).

Sugiro estratégias para o reaproveitamento dos espaços existentes, sala de leitura, laboratórios e outros. (UE 02, PR 07, Questão 5 do $3^{\circ}$ Questionário aberto).

Uma delas, a PR 08 que em resposta à Questão 2 do $1^{\circ}$ Questionário aberto afirmou que o espaço era restrito, em resposta à Questão 5 do $3^{\circ}$ Questionário aberto afirmou que não propunha porque achava o espaço suficiente. Quando em um momento de conversa questionei-a sobre a aparente contradição nas respostas, ela afirmou que havia respondido o primeiro questionário assim que chegou na escola, mas que com o tempo e as estratégias de organização do trabalho pedagógico realizadas pela coordenador, ela percebeu que a falta de um espaço para os momentos de coordenação não era problema, pois apesar de não se ter um local exclusivo para esses momentos, havia um espaço específico para os momentos de coordenação e de formação e isso era suficiente.

A partir da constatação das limitações de espaço físico, das diferentes expressões dos professores regentes das duas UE's e das alternativas apresentadas por ambas coordenadoras pedagógicas, compreendo a importância da organização do trabalho pedagógico do coordenador trazendo o professor a se constituir parceiro nessa organização para que juntos busquem soluções para as dificuldades que certamente surgem cotidianamente.

Retomando a fala da PR 08, UE 02, fica evidente a importância da atuação planejada do coordenador pedagógico no espaço escolar, buscando viabilizá-lo nos espaços disponíveis, pois segundo Souza e Placco (2010), de fato são muitas as barreiras postas de maneira a tentar impedir a formação continuada docente, porém o trabalho do coordenador pedagógico se constitui também em enfrentar tais desafios.

É evidente que na escola, o coordenador pedagógico não será o único responsável pela superação desses desafios que se interpõem à organização do espaço/tempo da coordenação pedagógica, mas ele, tendo consciência do seu papel, saberá que uma das suas atribuições é investir na construção de um trabalho pedagógico que favoreça a participação dos docentes nas reflexões sobre possíveis alternativas de organização e de utilização dos espaços físicos disponíveis, para que as atividades de formação e de planejamento das atividades didático-pedagógicas sejam efetivadas (SOUZA; PLACCO, 2013). 


\subsection{O espaço e o tempo da coordenação pedagógica: as ações, espelho das concepções}

Desde o início da minha pesquisa, venho buscando evidenciar os desafios e as possibilidades que o espaço/tempo da coordenação pedagógica traz em relação à formação continuada docente e desvelar as concepções que sustentam as práticas de formação continuada docente.

As concepções não se reproduzem apenas pela conceituação, elas são expressas desde práticas mais elementares até às práticas mais aprimoradas. Logo, muito além das falas, o planejamento das coordenadoras, as suas ações, sua organização, explicitam as concepções que embasam o seu trabalho de formação continuada.

Analisar os dois contextos educativos foi uma tarefa complexa porque me levou a lidar com concepções muitas vezes eivadas de sentidos historicamente fundamentados no senso comum. No vaivém das ideologias, um grande desafio foi buscar evidenciar tais concepções que tratam de edificar a prática formativa das coordenadoras pedagógicas que se por um lado ia em direção aos interesses hegemônicos, por outro apresentava possibilidades de superação desses mesmos interesses.

Foi pensando nesse desafio e na importância dos resultados que surgiriam a partir da exteriorização das concepções por meio das ações dos agentes educativos e, também, na clara manifestação das possibilidades oriundas desses contextos a partir do que foi observado e expresso pelos interlocutores que procurei confirmar o existente não apenas no ideal do grupo mas no real, concretamente.

\subsubsection{A formação continuada: o ideal e o real}

Muitas vezes mal compreendida e até desacreditada, a coordenação pedagógica na prática, tem revelado o distanciamento que ainda há entre o desejado, o esperado e o que acontece na realidade, sendo restringida a um papel meramente formal.

Um dos desafios postos ao coordenador pedagógico é o de fortalecer o diálogo a respeito dessa conquista favorecendo a revitalização desse espaço e tempo, ampliando as possibilidades do trabalho em uma perspectiva que vise ir além das questões meramente práticas, consolidando-o como espaço/tempo privilegiado para a formação continuada docente, ou seja, fortalecendo os momentos de formação continuada por dentro da escola. 
Teoricamente, a partir da leitura das respostas dos professores regentes das duas unidades de ensino, a dinâmica da coordenação pedagógica e da formação continuada se assemelham. No entanto, a partir da minha observação in lócus, observei que há uma grande diferença no que acontece entre uma escola e outra e também o distanciamento entre o que é dito e o que realmente acontece na prática.

Quando pedi que os professores e as coordenadoras expressassem em termos práticos como estão organizados os momentos da coordenação pedagógica, os interlocutores que responderam, deram respostas muito semelhantes em como está organizado o trabalho pedagógico. Vejamos algumas das respostas à Questão 1 do $1^{\circ}$ Questionário aberto para as coordenadoras pedagógicas e a Questão 1 do $3^{\circ}$ Questionário aberto para professores regentes:

"As coordenações acontecem nas terça, quarta e quinta feiras da semana. Sendo terça e quinta para a coordenação individual e quarta para a coordenação coletiva, onde todos se reúnem e trabalham juntos" CP 01, UE 01.

Quadro 5 - Organização do trabalho pedagógico nas UE's segundo os interlocutores

\begin{tabular}{|c|c|c|}
\hline \multicolumn{3}{|c|}{ PR 01, UE 01} \\
\hline Terça & Quarta & Quinta \\
\hline $\begin{array}{l}\text { Coordenação individual } \rightarrow \text { o } \\
\text { professor tem um momento para } \\
\text { analisar a sua turma, para } \\
\text { elaborar aula e atividades. }\end{array}$ & $\begin{array}{l}\text { Coordenação coletiva } \rightarrow \text { todos } \\
\text { os professores da escola se } \\
\text { reúnem para discutir assuntos } \\
\text { pedagógicos referentes à escola } \\
\text { toda e depois é dividida por: EF } \\
\text { séries iniciais, EF séries finais e } \\
\text { EM. }\end{array}$ & $\begin{array}{l}\text { Coordenação individual ou } \\
\text { reciclagem dos professores } \\
\text { através de cursos. }\end{array}$ \\
\hline \multicolumn{3}{|c|}{ PR 03, UE 01} \\
\hline Terça & Quarta & Quinta \\
\hline $\begin{array}{l}\text { Coordenação } \\
\text { ocorrendo o preparo de atividades } \\
\text { de acordo com o nível de } \\
\text { aprendizagem de cada grupo ou } \\
\text { indivíduo. }\end{array}$ & $\begin{array}{l}\text { Coordenação coletiva com: } \\
\text { informes, troca de experiências, } \\
\text { avaliação do trabalho } \\
\text { desenvolvido dentro de } \\
\text { determinada proposta, avaliação } \\
\text { de possibilidades de melhorias; } \\
\text { acompanhamento de alunos com } \\
\text { necessidades de assistência e } \\
\text { monitoramento constante e } \\
\text { outros. }\end{array}$ & Curso PNAIC Matemática. \\
\hline \multicolumn{3}{|c|}{ CP 02, UE 02} \\
\hline Terça & Quarta & Quinta \\
\hline $\begin{array}{l}\text { Atendimento individual por ano; } \\
\text { Formação continuada; } \\
\text { Organização do trabalho } \\
\text { pedagógico. }\end{array}$ & $\begin{array}{l}\text { Coordenação coletiva com } \\
\text { planejamento pedagógico; } \\
\text { Formação continuada; } \\
\text { Trabalho colaborativo. }\end{array}$ & $\begin{array}{l}\text { Atendimento individual por } \\
\text { ano; } \\
\text { Planejamento; } \\
\text { Acompanhamento } \\
\text { trabalho pedagógico. }\end{array}$ \\
\hline
\end{tabular}




\begin{tabular}{|l|l|l|}
\hline \multicolumn{1}{|c|}{ Terça } & \multicolumn{1}{|c|}{ Quarta } & \multicolumn{1}{c|}{ Quinta } \\
\hline $\begin{array}{l}\text { Coordenação individual com } \\
\text { organização do planejamento, } \\
\text { produção de materiais e/ou curso } \\
\text { de formação. }\end{array}$ & $\begin{array}{l}\text { Coordenação coletiva com } \\
\text { planejamento e/ou formação } \\
\text { continuada. }\end{array}$ & $\begin{array}{l}\text { Coordenação individual } \\
\text { com organização do } \\
\text { planejamento, produção de } \\
\text { materiais e/ou curso de } \\
\text { formação. }\end{array}$ \\
\hline \multicolumn{1}{|c|}{ Terça } & \multicolumn{1}{|c|}{ QR 02, UE 02 } \\
\hline $\begin{array}{l}\text { Coordenação individual. } \\
\text { Produção de materiais para as } \\
\text { aulas. }\end{array}$ & $\begin{array}{l}\text { Planejamento coletivo. } \\
\text { Formação. } \\
\text { Compartilhamento } \\
\text { experiências. }\end{array}$ & $\begin{array}{l}\text { Coordenação individual. } \\
\text { Produção de materiais, } \\
\text { jogos. } \\
\text { Colagem de atividades nos } \\
\text { cadernos, correção. }\end{array}$ \\
\hline
\end{tabular}

Fonte: Elaborado pela autora. Pesquisa de mestrado, 2015.

Como dito anteriormente, apesar de teoricamente, a partir das respostas dos interlocutores, haver essa semelhança na organização do trabalho pedagógico em ambas as unidades de ensino, na prática, o trabalho desenvolvido é bem diferenciado.

Analisando a dinâmica da formação por dentro da escola, eu poderia afirmar que o movimento para a sua organização e implementação é o mesmo de acordo com o pensamento de Cury (1985), ao afirmar que as instituições escolares tem a função de sistematizar o espontâneo para reelaborá-lo de forma crítica.

Sendo assim, é inerente ao trabalho de formação dos coordenadores pedagógicos essa forma de estabelecer uma organização que tenha por objetivo teorizar o espontâneo para em seguida sistematizar o teorizado, ou seja, refletir a respeito das manifestações que surgem do rico ambiente escolar para em seguida transformar em conhecimento didático-político.

Contudo é justamente nessa sistematização do trabalho de formação que surge a diferenciação dos trabalhos nas UE's, pois cada coordenadora pedagógica tem o seu próprio modo de agir, cada uma traz em si uma constituição histórica singular que a leva a pensamentos e ações diversificadas, e cada uma traz em si sua própria constituição.

Naturalmente que esse trabalho não será homogêneo também, porque cada unidade escolar possui uma dinâmica peculiar e necessidades específicas. Tais fatores são determinantes para o estabelecimento de um trabalho de igual modo singularizado.

É justamente por meio das ações que surgem a partir dessas especificidades que as concepções emergem de forma natural e serão essas concepções que irão delinear novas estratégias de ação a serem empreendidas pelas coordenadoras pedagógicas dos anos iniciais no espaço/tempo da coordenação pedagógica nas unidades escolares pesquisadas. 
Contudo, independente das singularidades das ações das coordenadoras pedagógicas nos espaços de atuação de cada uma, o que foi expresso pelos interlocutores está mais no nível ideal do que de fato acontece no espaço/tempo da coordenação pedagógica.

Conforme suas expressões há uma clara e rotineira organização dos momentos da coordenação pedagógica, inclusive de formação continuada, mas como já disse, essa organização remete-se muito mais ao que está escrito, ou prescrito na legislação sobre a organização do espaço/tempo da coordenação pedagógica do sendo o que realmente acontece.

\subsubsection{A formação continuada e a formação do formador}

Para que o coordenador tenha segurança em ser o formador dos professores no espaço escolar ele precisa se reconhecer e se posicionar como tal. Souza e Placco (2011) destacam a necessidade da formação continuada quando afirmam reconhecer as contribuições das pesquisas e reflexões acerca da função do coordenador pedagógico. Esse sujeito deve compreender o papel e a constituição da sua natureza profissional e a importância da sua atuação como formador no espaço/tempo da coordenação pedagógica.

Todavia, mesmo reconhecendo a importância desse espaço/tempo, como sendo um "momento conquistado através de luta, para o professor estudar, pesquisar, elaborar suas aulas, produzir material, momento de troca com os companheiros etc." (PR 04, UE 01, Questão 01 do $1^{\circ}$ Questionário aberto), o espaço/tempo da coordenação pedagógica como sendo de fato para a formação continuada, para a discussão dos problemas cotidianos, para a reflexão das concepções que embasam as práticas docentes e para a crítica do que vem sendo posto como verdade, ainda é incipiente.

Segundo Garrido (2011, p. 11), o coordenador pedagógico encontra obstáculos para exercer sua função porque é "atropelado pelas urgências e necessidades do cotidiano escolar". Ainda hoje, este é figura sem tradição na estrutura institucional tendo sua função mal delimitada e sem uma formação específica, precisando vencer seus medos e suas limitações para conquistar o seu espaço.

De acordo com a citada autora, a função do coordenador pedagógico ainda não está bem definida no âmbito das unidades de ensino como uma função reconhecida por seus pares. Contudo, suas atribuições já estão bem definidas na legislação vigente e no próprio Projeto Político Pedagógico da SEEDF: 
[...] o coordenador pedagógico escolhido pelo grupo deve articular a reflexão do pensar e do fazer pedagógico. Para tanto, precisa assumir o protagonismo no apoio ao trabalho pedagógico, à formação continuada, ao planejamento e ao desenvolvimento do PPP, sempre visando a aprendizagem de todos os estudantes. (DISTRITO FEDERAL, 2012, p. 112).

Entretanto, fica ao cargo do próprio coordenador pedagógico se reconhecer como coordenador, formador, articulador dos processos formativos e educativos nos espaços escolares. Cabe a ele desenvolver esse protagonismo que traz o PPP Carlos Mota ${ }^{5}$. Mas, considerando a importância da formação continuada docente para os avanços educacionais, como pensar que o formador dos professores tenha essa habilidade sem antes ter passado por uma formação inicial que seja?

Em 2012, a SEEDF em parceria com a Universidade de Brasília, ofertou para os coordenadores pedagógicos uma especialização em coordenação pedagógica que foi um avanço, sem dúvida, para o reconhecimento desses profissionais como articuladores dos processos de ensino e aprendizagem docente nos espaços nos quais atuam. Porém, a formação inicial deve ser complementada pela formação continuada, pois essa vai fortalecer a figura do coordenador pedagógico nos espaços coletivos para que ele possa exercer plenamente sua função formadora e promotora de mudanças no cotidiano escolar.

Esse é um ponto pacífico entre as coordenadoras das duas escolas: há uma falha da SEEDF em relação à formação do coordenador pedagógico.

$\mathrm{O}$ que identifiquei nas escolas pesquisadas foi a existência de duas coordenadoras pedagógicas que se dispuseram a assumir tal função com a intenção de colaborar com seus pares e com o bom desenvolvimento do trabalho pedagógico da escola.

Quando questionei a respeito dos motivos que as levaram a assumir tal responsabilidade responderam:

Essa escola, por ser uma escola grande que tem todos os segmentos, tinha uma
dificuldade muito grande de professor pegar a coordenação de séries iniciais.
Passaram dois professores de Ensino fundamental de quinta a oitava série,
professores de ensino médio, e não funcionava. Aí eu estava na escola já tinha uns
dez anos e eu resolvi encarar. Falei: "ano que vem vou pegar a coordenação, para a
gente poder ter um trabalho mais direcionado com séries iniciais". Como a escola é
muito grande, a coisa ficava muito perdida. A gente ficava meio desorientada aqui.
Tentava assim, fazer alguma coisa para séries iniciais, mas tem a questão do espaço.
Tinha a questão da diferença de idade, aluno de ensino médio com aluno pequeno.
Aí eu acabei resolvendo encarar. (CP 01, Entrevista).

${ }^{5}$ Projeto Político Pedagógico da Secretaria de Estado de Educação do Distrito Federal. 
Ficou claro na expressão da CP 01 que ela decidiu assumir a função de coordenadora pedagógica com a vontade de gerar mudança no trabalho pedagógico, na dinâmica escolar. Entretanto, é oportuno reconhecer que por mais simples que pareça ser o trabalho dentro de uma escola, ele é complexo e necessita ser fundamentado em boas bases teóricas para que seja efetivo em cumprir sua função precípua que é produzir e disseminar conhecimentos científicos buscando a transformação social (SAVIANI, 2012).

A CP 02 quando questionada, também, a respeito dos motivos que a levaram a assumir tal função afirmou:

\footnotetext{
Primeiro, eu gosto do trabalho na coordenação pedagógica. Eu gosto da articulação de trabalhar com o pedagógico, de trabalhar com o professor, de articular esse pedagógico, de estar aqui podendo trazer um pouco mais de formação, de estar auxiliando o professor, porque ao mesmo tempo que a gente colabora nesse trabalho a aprendizagem é muito grande e eu acho que eu tenho aptidão para ser coordenadora. (CP 02, Entrevista).
}

Não se pode negar que os sistemas motivacionais permitem representar o envolvimento afetivo do sujeito em uma atividade e isso, sem dúvida alguma, é um ponto importante para um bom desempenho na função de coordenar, mas não é o suficiente, é necessário o embasamento teórico.

Nesse sentido, Saviani afirma que

\begin{abstract}
Quando entendemos que a prática será tanto mais coerente e consistente, será tanto mais qualitativa, será tanto mais desenvolvida quanto mais consistente e desenvolvida for a teoria que a embasa, e que uma prática será transformada à medida que exista uma elaboração teórica que justifique a necessidade de sua transformação e que proponha as formas da transformação, estamos pensando a prática a partir da teoria. (SAVIANI, 2012, p. 91).
\end{abstract}

Entretanto, o autor afirma que também é preciso fazer o movimento inverso, ou seja, pensar a teoria a partir da prática, porque se a prática fundamenta a teoria, "seu critério de verdade e sua finalidade, isso significa que o desenvolvimento da teoria depende da prática” (SAVIANI, 2012, p. 91) e assim sendo, a prática tendo condições precárias, terá empecilhos, mas também desafios para o desenvolvimento da teoria. Impulsionará mecanismos efetivos e, portanto, também práticos, reformulando-os com a clareza que a teoria exige, tendo em vista a sua capacidade de se mover para a transformação efetiva dessas mesmas condições precárias.

Refletindo a respeito do que foi expresso por Saviani (2012) e a realidade da formação dos coordenadores pedagógicos, compreendo que a prática deve ter fundamentação 
teórica consolidada, mas não cristalizada para que essa prática seja reformulada e, por consequência, formule nova teoria constituindo a práxis. Logo, é imprescindível a formação do coordenador pedagógico para que ele venha transformar sua prática e produzir novos conhecimentos a partir das condições práticas dessas ações, mas sempre embasadas por uma teoria.

Apoiando-me na fala do citado autor, compreendo que a prática dos coordenadores pedagógicos ainda tem empecilhos, mas também desafios para o seu próprio desenvolvimento. Por isso, vejo a importância da formação desses indivíduos para impulsionar transformações efetivas na sua condição de sujeito no espaço/tempo da coordenação pedagógica e nas condições de trabalho dos professores.

A CP 02 reconhece que necessita desse embasamento teórico para aperfeiçoar suas ações como coordenadora e afirma:

$\mathrm{Eu}$ preciso de muita formação teórica, porque como eu não fui formada em pedagogia, só fiz o magistério, tudo que aprendi foi assim, em doses pequenas. Mas assim, foi muito útil porque a parte prática a gente trabalha muito, agora a fundamentação teórica eu acho que preciso sempre estar correndo atrás. Sempre estar buscando. Porque a fundamentação teórica é muito importante para a gente que está na coordenação. Até mesmo para respaldar, embasar o trabalho que você vai desenvolver com as professoras. (Entrevista).

A partir da compreensão da necessidade de buscar sua própria formação, dela se reconhecer como sujeito em constituição, de fundamentar teoricamente suas ações, identifiquei uma diferença na dinâmica e na organização do trabalho pedagógico das duas escolas.

Fica claro que a formação do coordenador pedagógico, pode se constituir em mecanismo de potencialização de reflexões sobre sua função e torna-se cada vez mais necessária para a consolidação de um trabalho pedagógico coeso e ancorado nas relações colaborativas. Assim, o coordenador pedagógico ao assumir o seu papel no processo formativo dos pares, vai se constituindo e constituindo o espaço/tempo da coordenação pedagógica em um espaço privilegiado de formação continuada.

Com essa consciência, a CP 02 aponta em vários momentos da entrevista a preocupação em estar atenta às necessidades formativas dos professores regentes. Afirma, também, que ao final do semestre realizou uma avaliação com eles, para a reestruturação do trabalho coletivo, declara que eles, tendo essa consciência, "pediram que tivesse mais formação" e acrescenta: "Então você vê, percebe aí que elas já estão conscientes da 
importância desses momentos e acostumadas com esses momentos de formação e que elas querem resgatar isso" (Entrevista).

Desse modo, fica claro que para o coordenador pedagógico desempenhar a sua função de formador, ele deverá se formar buscando a cada dia se constituir sujeito no espaço escolar no qual atua e ser o eixo norteador das reflexões sobre as dificuldades e as possibilidades de ensino e de aprendizagem que emergem do ambiente escolar.

\title{
6.2.3 A formação continuada e a constituição do sujeito coordenador
}

Ainda em relação à organização do trabalho de formação na coordenação, perguntei sobre os textos que mobilizavam ou iniciavam as discussões no grupo. A CP 01 mencionou que recorria aos artigos da revista Nova Escola, ou algum outro material trazido ou sugerido pelos professores regentes, mas, segundo ela, ainda há certa resistência quanto à participação dos professores nos momentos da coordenação coletiva, espaço destinado à formação continuada docente, afirmando que

\begin{abstract}
É assim. Quarta feira, às vezes os professores não vão [...] vem para a coordenação pedagógica porque estão com um monte de coisa para fazer, tem diário para preencher, exercício pra corrigir [...] Então, eu tento trazê-los para a coordenação. Porque coordenação pedagógica é para discutir outra coisa, não é para estar fazendo atividade de sala de aula ou [...] Infelizmente é. Então, eu sempre estou buscando as professoras. Quando eu chego, falo: Ó, vamos lá! Elas respondem: Não, não quero não! Eu falo: Vamos lá, isso aqui é legal, a gente vai conversar sobre alguma coisa que vocês vão gostar! Aí acaba que eu consigo trabalhar com elas assim. (CP 01).
\end{abstract}

Isso me permite perceber indicadores que apontam para a cultura da não valorização do espaço/tempo da coordenação pedagógica e dos momentos de formação continuada no local de trabalho, além da não valorização do outro como sujeito de possibilidades.

Também se apresentam indícios de dificuldade da CP 01 no ato de interagir e dialogar pedagogicamente com os pares, fato que interfere no processo de construção coletiva de alternativas e soluções para os problemas que surgem no cotidiano da escola.

É possível perceber que, ao se dispor a desempenhar a função de coordenador pedagógico, o sujeito pode passar, em sua nova função, por momentos de desânimo, enfrentamentos e embates gerados pela diferença da compreensão da sua função, contudo, são esses momentos coletivos que devem trazer novos elementos para a sua constituição como sujeito e se configuram como momentos ricos e propícios para a construção da sua 
territorialidade e, por consequência, a constituição do espaço e do tempo da coordenação pedagógica como espaço privilegiado para a formação continuada docente no seu próprio local de trabalho (FERNANDES, 2012).

Na UE 01, essa territorialidade ainda está em construção. A CP 01 ainda precisa usar de artifícios para convencer os professores da importância de suas ações e de construções possíveis a partir das reflexões naquele espaço.

Para isso, ela precisa buscar cotidianamente a compreensão do seu papel e considerar que a relação pedagógica é uma relação de luta em que conhecer o real possibilita a superação do senso comum dentro de uma perspectiva de totalidade (CURY, 1985).

Nesse sentido, o apoio do coletivo é fundamental, tanto coordenadores pedagógicos como professores regentes devem afastar qualquer tendência a desenvolver o trabalho de forma solitária, individualizada, e se colocarem à disposição de realizar um trabalho que envolva todos da escola para que possam atender as necessidades educativas tanto dos alunos como do próprio grupo.

De acordo com Gouveia e Placco (2013), o coordenador pedagógico é o responsável por iniciar o movimento do trabalho colaborativo fundamental para o desenvolvimento da formação continuada docente no âmbito da escola. Este deve se colocar ao lado do professor e propor

[...] bons momentos de formação nos horários de trabalho coletivo previstos na escola para organizar grupos de estudo, planejar as ações didáticas junto com os professores, fazer as orientações por séries, exercer, de fato, o papel de articulador de aprendizagens. (GOUVEIA; PLACCO, 2013, p. 70).

De igual modo, o grupo também deve reconhecer e valorizar a figura e o trabalho do coordenador pedagógico. A fala da CP 01 que trago a seguir apresenta o indício de que apesar de haver uma boa relação entre ela e os professores, essa relação não se estabelece a partir da autoridade da coordenadora pedagógica no seu espaço de atuação:

Eu não gosto de impor nada. Eu vou conversando com as meninas e dessa forma eu consigo as coisas que eu quero. A gente senta, conversa e negocia. Por exemplo, final do ano passado eu fiz uma avaliação com os alunos para ver o nível deles para o ano seguinte. Era uma coisa que desde o primeiro ano eu tentei, mas não conseguia e no segundo ano eu já consegui. Eu elaborei a prova e eu passei para os professores e eles aplicaram as provas e aí puderam ver os avanços e a gente ver que não é para ver o trabalho do professor, é para ver o avanço dos alunos. Então, eu achei muito gratificante. (CP 01). 
A partir dessas expressões, constato que a CP 01 vive um dilema de ser ou não autoritária e ter que provar para os professores que o seu trabalho é exercido com responsabilidade e objetiva a melhoria da qualidade do trabalho deles também.

Essa autoridade não pode ser imposta, mas construída, e essa construção pressupõe o investimento na formação continuada do professor, em demonstrar a valorização e o respeito ao trabalho dos professores, responsabilidade e autonomia.

É importante mostrar que os momentos de formação no espaço/tempo da coordenação pedagógica são propícios para a discussão, a reflexão, o posicionamento crítico, o planejamento das ações coletivas, a socialização dos conhecimentos ali constituídos, a avaliação dos processos de ensino e de aprendizagem ocorridos na escola, tendo a realidade como base da investigação coletiva e permanente.

O grupo docente da UE 01 parece ainda não ter compreendido que o trabalho do coordenador pedagógico tem o objetivo de favorecer o trabalho deles e, por consequência, favorecer a aprendizagem dos alunos.

A avaliação dos alunos como planejada pela CP 01 quando trabalhada na concepção formativa, trará um impacto em todas as dimensões do trabalho pedagógico, pois promoverá não apenas o desenvolvimento dos alunos, mas também o trabalho do professor e novamente o trabalho do coordenador pedagógico, constituindo a formação num movimento em espiral, contínuo, cíclico e ascendente.

Pela fala da CP 01 é possível observar que tanto ela quanto o grupo devem buscar compreender que é fundamental fazer a avaliação do próprio trabalho não encarando esta ação como fiscalização de práticas certas ou erradas, mas como possibilidade de superação de fragilidades, de visualização de possibilidade de saltos qualitativos e de construir coletivamente caminhos que norteiem práticas diversificadas que promovam a aprendizagem dos alunos.

Como se vê, na UE 01 há indícios que me levam a crer que ainda falta o autorreconhecimento da coordenadora como autoridade no espaço em que atua e nas atividades que desenvolve. Para Souza e Placco (2011), a constituição dessa autoridade se dará primeiro, a partir do reconhecimento de seus próprios conhecimentos, sua competência e da organização do seu próprio trabalho.

Em seguida, a partir da sua atuação, virá o reconhecimento por parte dos professores e o apoio ao seu trabalho por parte da equipe gestora, no sentido de fortalecê-la 
para a realização do trabalho na perspectiva da valorização da troca, do respeito e da autonomia.

De fato, torna-se imprescindível a compreensão do lugar desse profissional no espaço educativo; um lugar interligado com as necessidades da escola na contemporaneidade em consonância com os interesses pedagógicos da coletividade e os interesses dos indivíduos que transitam nos espaços educativos, ou seja, um papel que precisa urgentemente ser consolidado para desencadear projetos autênticos de construção pedagógica que privilegie o diálogo, a troca de experiências; um espaço de interação, onde os pares aprendam um com o outro e se vejam corresponsáveis pelo sucesso do trabalho, um lugar onde se concretize a práxis.

A DR 01, em um momento de conversa reconheceu que precisa dar maior apoio ao trabalho da coordenação pedagógica na escola para que o trabalho coletivo seja fortalecido e reflita na sala de aula com a concretização da aprendizagem dos alunos, mas que a própria dinâmica da escola não tem favorecido esse apoio. Todavia, pude observar que ela dá liberdade para as ações dos coordenadores pedagógicos com o grupo de professores.

Além dessa carência no apoio explicitado pela diretora, pude perceber que existem, de acordo com as concepções construídas historicamente, fatores que dificultam o desempenho da coordenadora pedagógica na UE 01, entre esses fatores, destacam-se o não reconhecimento real da importância do espaço/tempo da coordenação pedagógica, não compreensão da formação continuada docente que deve acontecer naquele espaço/tempo a partir das demandas do cotidiano escolar e a falta da clara compreensão da CP 01 em relação a sua real função no interior da escola.

$\mathrm{O}$ dia em que fui à UE 01 fazer o primeiro contato, encontrei a CP $01 \mathrm{em}$ sala de aula substituindo uma professora que estava de licença para tratamento de saúde. Durante a entrevista perguntei a ela qual era sua postura diante das demandas de ser coordenadora pedagógica e ainda ter a responsabilidade da formação continuada. A esse respeito ela disse que

É difícil conciliar. Porque o coordenador é o faz tudo. Infelizmente, a gente está ali tirando uma xerox, está ali em uma turma que o professor faltou, está atendendo ao pai, está resolvendo alguma ocorrência. É difícil, mas é assim. Na quarta feira geralmente, eu não pego nada e a direção sabe. Eu sempre converso com a DR 01, mas quarta feira a gente não tem conversa. Se o professor falta na segunda e terça eu entro, na quarta não entro porque quarta é a coordenação pedagógica. Nesse ponto não tem negociação, a gente cuida da coordenação mesmo. (Entrevista). 
Placco e Silva (2011) alerta para a necessidade de o coordenador pedagógico ter a sensibilidade de olhar e refletir a respeito da dinâmica que o envolve e da sua condição naquela dinâmica para que ele possa organizar o seu cronograma de atividades, pois essa organização vai permitir que desempenhe melhor sua função favorecendo a confiança do professor e a organização do trabalho de cada um e do trabalho coletivo.

Como pensar na dinâmica da formação continuada no espaço da coordenação pedagógica com a coordenadora não tendo condições de planejá-la, organizá-la? A atuação do coordenador pedagógico pressupõe planejamento, momentos de estudo, de seleção e de organização prévia de materiais, ou seja, organizar o seu fazer pedagógico para desempenhar melhor a sua função (PLACCO; SILVA, 2011).

Observo que a CP 01 precisa se reconhecer coordenadora e ocupar seu espaço para que haja a valorização do espaço e do tempo da coordenação pedagógica, assim como a valorização do seu trabalho. O pouco envolvimento demonstrado pelos professores não pode ser motivo de estagnação do desenvolvimento do trabalho pedagógico da escola.

Acredito que se posicionar assumindo o seu papel, além de possibilitar um salto qualitativo na organização do trabalho pedagógico e na construção das atividades de planejamento, também fomentará a integração dos pares, incluindo a coordenação pedagógica e a equipe gestora (MUNDIM, 2011).

Já a CP 02, falando do seu papel afirma:

Eu sempre bato nessa tecla que eu sou coordenadora. Eu estou em constante processo de constituição. Mas eu acredito que eu tenho, buscado a minha constituição como sujeito porque eu sei da minha função dentro da escola. (Entrevista).

Pela expressão da CP 02, identifico que ela se reconhece coordenadora e esse reconhecimento de fato impacta na dinâmica dos momentos de formação no espaço/tempo da coordenação pedagógica com uma organização e o levantamento das demandas formativas com os professores, o planejamento prévio traçando os objetivos da formação e contando com a participação da DR 02.

A respeito da formação realizada no espaço/tempo da coordenação pedagógica a DR 02 compreende e afirma que é

De extrema importância, pois é notório o crescimento do grupo e o interesse do mesmo em aprender e participar das formações. Além do reflexo que essas formações tem dentro da sala de aula. (Questão 07 do Questionário). 
E a respeito do papel do coordenador na escola CP 02 e DR 02 afirmam que,

Há uns anos atrás a gente tinha a ideia de que o coordenador era para cobrir turma de professor que faltava, era para rodar atividade, era para fazer cartaz. Eu não tenho essa visão. E assim, em qualquer escola que eu vá trabalhar, eu só fico como coordenadora se a escola também entender esse papel, que eu estou aqui para trabalhar com o pedagógico, eu estou aqui como mediadora. Agora, nada me impede de em um momento vigiar ${ }^{6}$ um recreio. Não tem ninguém? Eu me proponho, porque a gente tem sempre que se ajudar dentro da escola. Mas o meu trabalho é extremamente, estritamente pedagógico. (Entrevista).

O coordenador na escola desempenha uma função importante no espaço da coordenação pedagógica e não tem a devida valorização do cargo que ocupa, nem pela atual Secretaria nem pelo governo que não incentiva o cargo em valores econômicos e nem valoriza no aspecto de ser um cargo formador colocando o mesmo como professor substituto, o famoso "tapa buraco", destorcendo a sua importância dentro da escola. (Questionário, Livre expressão).

Nesse sentido, é válido destacar a importância de o coordenador ter consciência das suas atribuições e a respeito da necessidade do coordenador pedagógico se constituir coordenador pedagógico, Mundim afirma que:

[...] Essa constatação nos remete à hipótese de que quando o coordenador pedagógico se posiciona como um intelectual que pensa sua prática, aliada a uma fundamentação teórica, este consegue mobilizar mudanças, assumindo-se como um profissional em constante constituição e consciente de que tem de enfrentar desafios. (MUNDIM, 2011, p. 126).

A autora destaca, ainda, que é essencial a adoção da condição de sujeito pelos coordenadores pedagógicos para que se rompa com os limites dos imediatismos que o contexto escolar impõe, favorecendo modificações nesses limites e gerando novas opções de ação dos coordenadores pedagógicos dentro da trama social em que atuam (MUNDIM, 2011).

Na UE 02, a DR 02 afirmou que sempre "apoiou, participou, facilitou e deu o suporte necessário nas coordenações pedagógicas ajudando no direcionamento e escolhas de temas para as formações". De fato, antes de entrar de licença médica, a DR 02 planejou com a CP 02 e sempre esteve presente nos momentos de formação nos dois turnos.

Não poderia deixar de destacar que a dinâmica de ambas as Unidades Escolares é muito diferente, justamente por uma ser escola classe e outra ser centro educacional a possibilidade das diretoras estarem atuando mais efetivamente junto a coordenação são muito peculiares, pois como vimos anteriormente a UE 01 é um centro educacional que tem em seu

\footnotetext{
${ }^{6}$ Vigiar: usado no sentido de olhar as crianças pequenas para evitar brigas e auxiliar nas situações de quedas e possíveis ferimentos.
} 
quadro 100 professores e atende uma média de 1500 alunos de todas as etapas da educação básica, isto é, desde a educação infantil até o ensino médio e também EJA, já a UE 02, tem em seu quadro 10 professores regentes e atende uma média de 300 alunos dos anos iniciais do ensino fundamental, sendo assim, a dinâmica escolar e de ação da equipe de direção, docentes e equipe administrativa. Diante dessa realidade não há como a dinâmica de ambas não ser bem diferenciada.

O reconhecimento da importância do trabalho do coordenador pedagógico foi assinalado na fala de todos os interlocutores, porém, a partir da observação dos momentos da coordenação coletiva nem sempre essa valorização ficou evidente.

Esse reconhecimento de si como sujeito da própria função, da importância do seu papel de coordenador pedagógico nos momentos de formação no espaço/tempo da coordenação pedagógica é essencial para o desenvolvimento do trabalho pedagógico da escola e será fundamental para a superação de concepções cristalizadas e que favorecem a manutenção do status quo no qual hoje está situada a sua ação.

\subsubsection{A formação continuada e o desafio de fortalecer o espaço/tempo da coordenação pedagógica}

Como visto anteriormente, de acordo com Saviani (2002), a ideia da coordenação pedagógica se estruturou no cenário da educação brasileira com o objetivo de realizar um acompanhamento sistemático do trabalho desenvolvido pelos professores nos espaços escolares e veio sendo representado pela figura do especialista da educação.

É compreensível que em função da sua origem histórica, dissociar a coordenação pedagógica da ideia de fiscalização, do controle do processo educativo ou de suporte às demandas práticas do dia a dia escolar tem sido tarefa árdua, principalmente, para os próprios coordenadores pedagógicos que precisam se constituir coordenadores pedagógicos, se reconhecendo como sujeitos no processo formativo docente no espaço escolar, para daí fomentar o caráter estritamente pedagógico da sua função.

A imagem do coordenador pedagógico está muito associada ainda àquele que está na escola para ajudar a solucionar questões emergenciais para reproduzir material para os professores.

O espaço da coordenação pedagógica deve ser concebido e valorizado como espaço de reflexão crítica e constante sobre a prática de sala de aula e as concepções que as 
embasa, tendo a coordenação pedagógica, entre suas atribuições, uma boa estratégia de fortalecimento da formação continuada docente no próprio local de trabalho. Mas, o caminho inverso também pode ser trilhado. A realização da formação continuada nesse espaço/tempo também deve fortalecer e suscitar a sua valorização.

Pelas respostas dos professores regentes de ambas as unidades de ensino, o espaço/tempo da coordenação pedagógica na atual configuração foi um ganho imenso. Os professores que vivenciaram a organização anterior à jornada ampliada, na qual a carga horária dos professores de 40 horas semanais das séries iniciais era de 32 horas semanais de regência e 8 horas semanais de coordenação, falam da atual realidade e compreendem que essa configuração tem favorecido uma melhor estrutura ao trabalho pedagógico desenvolvido por eles.

Quando em um momento de conversa questionei se algum deles gostaria de voltar à antiga configuração, a resposta foi unânime: "Não!". Isso significa que, de modo geral, apesar de ainda não ter desvinculado totalmente a ideia da coordenação pedagógica da questão da vigilância, da prescrição, e ainda, sem terem ao certo a consciência do potencial do espaço/tempo da coordenação pedagógica, para eles, as horas de coordenação pedagógica são importantes para o bom desenvolvimento do trabalho pedagógico.

Nem preciso dizer que a prática da coordenação pedagógica na SEEDF, ainda está atrelada à ideia de normatização, mas que teoricamente aparenta avançar para uma ideia de ação refletida criticamente junto ao professor, buscando diante das necessidades reais, as mudanças das práticas existentes e no sentido de ser da educação.

Faço essa afirmação porque no seu Projeto Político Pedagógico, a SEEDF traz a concepção da coordenação pedagógica como

\footnotetext{
Um espaço/tempo vivo, dinâmico, fundamentado na dialogicidade entre a comunidade escolar e a extraescolar, entre o real e o prescrito, entre a teoria e a prática, na busca da concretização do PPP da escola e, assim, vencer os desafios que inviabilizam as ações coletivas para a construção da educação pública de qualidade. (DISTRITO FEDERAL, 2012, p. 112).
}

Disse "aparenta", porque apesar de parecer que houve um grande avanço, o atual Projeto Político Pedagógico do Distrito Federal atribui ao espaço/tempo da coordenação pedagógica um diálogo entre o que está fora e o que está dentro da escola, entre o que representa a teoria e a prática para a construção de uma educação de qualidade.

É exatamente aí que se pode pressupor que o PPP traz uma visão de homem e sociedade atuantes, que não se submetem às condições impostas, que se mobilizam para 
transformar as suas ações, no sentido de juntos transcenderem os limites que surgem no cotidiano escolar para a concretização de uma educação de qualidade. Todavia, em que sentido esse diálogo tem sido estabelecido? Privilegiando o conhecimento espontâneo e a cultura popular? (SAVIANI, 2012).

Enquanto forem banalizados o estudo, a pesquisa, o pensamento, a crítica e a produção de conhecimento científico, a educação, bem como a dimensão educativa da escola e dos processos formativos que ela possibilita, esse espaço de socialização e democratização do saber servirá apenas para concretizar a educação qualitativamente favorável para formar trabalhadores para a ideologia hegemônica.

As ideologias coexistem nos espaços e nas ações dos professores. Vemos essa contradição nas expressões de algumas das professoras regentes das unidades de ensino, a UE 01 e a UE 02, em relação ao significado da coordenação pedagógica para elas:

"Momento de troca de experiências e aprendizagem, além de aperfeiçoamento e reflexão da prática” (UE 01, PR 08, Questão 1 do $1^{\circ}$ Questionário aberto).

"Momento de planejar ações para o alcance de objetivos pretendidos; com elaboração de materiais e estratégias; além de troca de experiências com os demais colegas" (UE 01, PR 02, Questão 1 do $1^{\circ}$ Questionário aberto).

"É o momento em que o professor aproveita para planejar as suas aulas e produzir os materiais didáticos” (UE 01, PR 08, Questão 1 do $1^{\circ}$ Questionário aberto).

"Significa um momento para buscar atividades que atendam à demanda da minha turma” (UE 01, PR 03, Questão 1 do $1^{\circ}$ Questionário aberto).

"Um espaço de aprendizado, de troca de ideias, e principalmente de formação" (UE 02, PR 07, Questão 1 do $1^{\circ}$ Questionário aberto).

"Momento para estudo (formação continuada), planejamento das aulas e sobretudo troca de experiências e informações entre nós, professores" (UE 02, PR 10, Questão 1 do $1^{\circ}$ Questionário aberto).

"Momento de estudo e planejamento que visa cumprir o projeto pedagógico da instituição de ensino" (UE 02, PR 06, Questão 1 do $1^{\circ}$ Questionário aberto).

"É o espaço que o professor tem para planejar suas aulas trocar ideias com os colegas, receber dicas" (UE 02, PR 09, Questão 1 do $1^{\circ}$ Questionário aberto).

Como se pode observar, enquanto umas professoras regentes concebem a coordenação pedagógica como um tempo para refletir, outras a concebem como o momento apenas de agir. 
É curioso e acredito ser importante destacar que nenhum dos professores regentes da UE 01 ao se referiram à coordenação pedagógica utilizou a expressão "formação", "formação continuada" ou "formação docente". Na UE 02, houve a ocorrência do termo "formação" em três respostas, "formação permanente" em uma resposta e "formação continuada" em outra resposta. Totalizando cinco ocorrências relacionando a coordenação pedagógica à formação do professor.

A falta dessa ocorrência no grupo dos professores da UE 01 indica que o espaço/tempo da coordenação pedagógica ainda não é visto como um espaço destinado e mais que isso, conquistado para que aconteça a formação continuada docente na própria escola.

É possível identificar que as concepções dos professores regentes sobre coordenação pedagógica se estruturam e se reconfiguram de acordo com os contextos, político e social que se corporificam na realidade de cada uma de modo que fica claro que nas duas escolas, a coordenação pedagógica tem vivido tempos de incertezas, mas, também, de significativas transformações.

De acordo com as pesquisas de Almeida e Placco $(2010,2011,2013)$ e Araújo e Mundim (2012), a coordenação pedagógica é compreendida como espaço/tempo primordial para o planejamento das ações coletivas, para reflexão, para a troca de experiências, para a colaboração, para a organização do trabalho pedagógico coletivo, buscando transformar as concepções descontextualizadas que embasam o trabalho docente na perspectiva do trabalho individualizado, fragmentado, isolado.

Entretanto, para que o espaço e o tempo da coordenação pedagógica se tornem de fato propícios para construções coletivas que alavanquem transformações sociais, desligandose das concepções historicamente construídas, é fundamental que o trabalho pedagógico desenvolvido ofereça efetivamente aos professores a possibilidade de construção do PPP com comprometido com o rompimento da exploração do homem pelo homem, em que cada professor possa ter a clareza do campo de lutas hegemônicas no qual são peças fundamentais.

Nessa perspectiva, o coordenador pedagógico assume a responsabilidade de organizar o espaço/tempo da coordenação pedagógica possibilitando o entendimento da necessidade de desenvolver a cultura que contribui para a formação do homem enquanto homem. Para isso, ele deverá tomar consciência de sua profissionalidade, de sua responsabilidade ética e de modo intencional e sistematizado, vir a produzir novos conhecimentos para serem compartilhados com seus pares visando estabelecer uma dimensão 
agregadora em suas ações, no intuito de articular as experiências e os saberes produzidos na escola.

Segundo Saviani (1988), essa ação, nesse caso do coordenador, na realidade vai possibilitar que ele alcance um nível maior de consciência de si e das reais necessidades de criar novas situações formativas, ou seja, transformar sua realidade em função dos seus objetivos e, também, abrir espaço para a construção da autonomia do trabalho docente, bem como a construção da identidade e da autonomia da escola.

Na concepção marxista, o trabalho é concretizado na articulação da transformação e da humanização considerando a intenção do homem sobre a natureza, ou seja, na reflexão e na ação, na práxis, que desencadeia processos analíticos e naturalmente de crítica e de emancipação do homem. A conquista do espaço/tempo da coordenação pedagógica deve remeter o coletivo à essa compreensão, de que ele se constitui em poderosa possibilidade de transformação e emancipação humana.

Mais adiante, busco compreender a ação do coordenador pedagógico na escola da atualidade, o seu papel e a sua responsabilidade de fortalecer a formação no espaço/tempo da coordenação pedagógica.

Essa compreensão vai me ajudar a situar as relações estabelecidas nas unidades de ensino pesquisadas, a atuação de ambas as coordenadoras no ambiente escolar e possibilitar um aprofundamento na compreensão das ações e concepções que embasam as suas práticas e que dizem respeito ao modo que cada uma escolhe para percorrer os seus caminhos e se fortalecer na função.

\subsubsection{A Formação continuada e o desafio de fortalecê-la no espaço/tempo da coordenação pedagógica}

Nesse momento é pertinente trazer para análise na pesquisa a forma como está organizado o espaço e o tempo da coordenação pedagógica e como está pensada e é operacionalizada a formação continuada nesse espaço/tempo nas escolas pesquisadas.

Trouxe anteriormente a importância da reflexão a respeito do espaço e do tempo da coordenação pedagógica e agora considero fundamental, também, trazer a questão da formação continuada docente nesse espaço/tempo e da necessidade do seu fortalecimento a partir da ótica dos interlocutores da pesquisa, ou seja, as diretoras, as coordenadoras pedagógicas, os professores regentes. 
No Distrito Federal, a própria Secretaria de Educação, oferece formação continuada aos professores através da Escola de Aperfeiçoamento dos Profissionais da Educação do Distrito Federal - EAPE ${ }^{7}$. Essa formação nem sempre acontece no espaço escolar, mas sempre acontece no tempo, isto é, nos horários da coordenação pedagógica.

Há cursos que são ministrados por formadores e nesses, os professores vão aos pólos da própria EAPE. Mas, também, há cursos que são ministrados aos coordenadores pedagógicos e estes repassam o curso para os professores no espaço/tempo da coordenação pedagógica. E há, ainda, ou devia haver, a formação continuada que acontece no espaço/tempo da coordenação pedagógica a partir das demandas que se dão a partir do cotidiano escolar e suas necessidades, no qual o coordenador pedagógico é o formador.

A minha crítica em relação à formação idealizada e ofertada pela EAPE ou pelo MEC, ou seja, a formação que é pensada no nível macro é a de que ela pode contribuir com a inovação na prática do professor, mas seu impacto pode não ser significativo justamente por não considerar as especificidades do ambiente, do coletivo docente, do grupo de alunos e da comunidade na qual a escola está inserida.

Acredito que a formação que tem por objetivo manter o professor na condição de receptor, ou seja, de receber pronto o que ele pode muito bem pensar e criar por si só, não favorece que ele se reconheça como sujeito que tem plena condição de se posicionar criticamente diante das situações e perde a oportunidade de alavancar transformações refletidas, conscientes na sua prática e, consequentemente, alavancar transformações na realidade social na qual interfere.

Dessa maneira, essa formação generalizada tem se configurado na maior parte das vezes em ações mecanicistas e lineares, não trazendo os conhecimentos à contextualização e à reflexão crítica, colocando-se a serviço da reprodução do sistema, favorecendo a manutenção do mesmo e, o mais grave, com o consentimento do coletivo docente que o reproduz.

Historicamente, segundo Imbernón (2010), a formação continuada baseia-se em problemas genéricos, padronizados, aos quais cabe a ação de um especialista com uma solução de igual modo genérica. Essa forma de pensar a formação como uma questão genérica levou a organização de um modelo, um treinamento, no qual os professores participam e lá adquirem as "habilidades certas" para solucionar problemas uniformes.

\footnotetext{
${ }^{7}$ Uma escola que tem como missão a formação continuada dos profissionais da Educação no Distrito Federal em consonância com as demandas da Rede Pública de ensino do DF, contribuindo para a educação de qualidade social e a valorização profissional dos educadores. 〈http://www.eape.se.df.gov.br/?page_id=58>. Acesso em: 17 ago. 2014.
} 
A esse respeito a CP 02 afirma que a formação que a SEEDF, via EAPE tem oferecido para os coordenadores permanece com a lógica reprodutivista ao afirmar que

\begin{abstract}
As formações que tem para coordenador não são para a formação do coordenador. $\mathrm{O}$ coordenador faz o curso para repassar para o professor e aí o que acontece? Quem não teve essa trajetória que eu tive, a sorte de pegar diretor e professores tão bons que foram norteando meu caminho, como é que eles vão fazer? Eles não tem como fazer! E a grande maioria dos coordenadores que eu conheço que tem essa visão, são coordenadores que foram trabalhados em escolas em que a direção é pedagógica, em que o grupo é muito bom. (Entrevista).
\end{abstract}

Apesar da SEEDF não exigir uma formação específica para o professor exercer a função de coordenador pedagógico dando a impressão de democratizar o acesso à função, ela na verdade permite que os professores que assumem essa responsabilidade não tenham a clareza da sua função e a importância de se ter embasamento teórico sobre gestão escolar, didática, currículo, por exemplo, para exercê-la.

A partir da fala da CP 02, fica claro que a SEEDF ainda concebe e executa a formação continuada docente de acordo com a lógica do sistema vigente, segundo seus objetivos, disseminando uma formação que veicula a condição de adaptação do homem à lógica mercantil, objetivando o fortalecimento de ações pedagógicas pragmáticas, pois seguindo essa ordem capitalista, a finalidade da formação genérica não será a da produção do conhecimento, mas a de instrumentalizar os professores para que o conhecimento por ele adquirido possa ser transformado em riqueza efetiva para o país tendo o capital, o mercado como centralidade.

Todavia, a partir da parceria com a Universidade de Brasília, vejo a possibilidade de transformação dessa concepção tão enraizada na ordem social hegemônica. Com os cursos ofertados aos professores da rede pública, coordenados pedagogicamente pelos professores da universidade, o rumo das discussões tem sido outro. Há uma preocupação em encaminhar as discussões sobre educação para a ótica crítica buscando refletir a atuação dos agentes educativos, suas condições específicas de trabalho, suas ações concretas, estratégias e táticas para fortalecer a educação como possibilidade de emancipação.

Mesmo havendo essa possibilidade formativa traçada por uma racionalidade que valoriza o trabalho como princípio educativo e a práxis como fundamental para a emancipação do professor, há alguns entraves que dificultam o acesso e a permanência dos professores nos cursos. 
Segundo Quixadá Viana e Aragão (2014), a respeito de uma especialização voltada para os gestores da SEEDF, alguns dos entraves são: o excesso de atribuições dos gestores na escola e a falta de tempo para realizar as leituras e atividades do curso incluindo o trabalho de conclusão, ou seja, a monografia; o tempo que o professor ficou sem estudar após a sua formação inicial e o pouco tempo destinado à sua formação continuada; dificuldade com o uso de novas tecnologias não havendo adaptação ao ambiente virtual.

Apesar de as autoras trazerem as dificuldades específicas de uma especialização para gestores, me sinto no direito de ampliar para os outros cursos, inclusive da especialização em coordenação pedagógica por suas características e porque tive a oportunidade de ser aluna tanto no curso de gestão escolar, quando estava na direção de uma escola, como no curso de coordenação pedagógica quando estava na função de coordenadora pedagógica.

É evidente que tenho que reconhecer a importância dessa parceria para a ampliação da visão dos professores da SEEDF em relação à formação continuada, a educação, à aprendizagem dos alunos, à renovação das práticas pedagógicas, à importância do coordenador pedagógico, entre outras questões.

No entanto, como já pontuei na parte teórica, a formação continuada docente dentro da escola, tem a possibilidade de considerar questões relacionadas aos processos educativos tendo como base o cotidiano escolar, o que é visto, discutido, pensado e vivido pelo coletivo, pelos alunos, pela comunidade e sob essa ótica vai exercer função fundamental para fortalecer a função da escola e a formação humana.

Segundo Bruno e Christov (2010), essa formação tem o coordenador pedagógico como o articulador das construções coletivas, se posicionando como agente responsável pela coordenação da formação continuada no cotidiano escolar e a partir desse cotidiano uma formação emancipatória tendo como pressuposto fundamental, o conhecimento.

Segundo Imbernón (2010), a formação continuada docente diante da sua complexidade requer dar a palavra aos protagonistas das ações, responsabilizando-os por sua própria formação e pelo desenvolvimento do coletivo para sua criação identitária. Ele, também, afirma que a escola, sendo o foco do processo formativo, promove a autonomia dos atores que nela atuam e reconstrói sua própria história e, consequentemente, a cultura da comunidade da qual faz parte.

Todavia, é interessante destacar que ainda há professores regentes, coordenadores pedagógicos e diretores que não reconhecem como formação os momentos coletivos da 
coordenação pedagógica. Quando questionados a respeito de qual tem sido a dinâmica da formação continuada no espaço/tempo da coordenação pedagógica obtive respostas como:

“Através de cursos oferecidos pela SEEDF-PNAIC ${ }^{8}$ no momento" (PR 01, UE 01, Questão 02 do $3^{\circ}$ Questionário Aberto).

Ou quando questionada a respeito do suporte oferecido pela equipe gestora aos momentos de formação na escola:

“[...] Tentamos encaminhá-los para os cursos da EAPE” (DRA 01, Questão 08).

Aqui fica claro que ideias de formação construídas com o tempo ainda estão arraigadas nas mentes daqueles que trabalham na educação e refletem nas concepções de formação e na dinâmica da formação continuada docente que é realizada dentro da escola que, por sua vez, reflete-se na dinâmica escolar.

De acordo com Souza e Placco (2013), por ser uma conquista relativamente recente as pesquisas sobre a coordenação pedagógica, sua configuração como espaço de construção coletiva e de formação continuada ainda são reduzidas, tornando-se um desafio expandi-la, fortalecê-la. Entretanto, para vencer esse desafio e fortalecer a formação continuada docente nesse espaço/tempo, ela deverá ser valorizada principalmente pelos professores que não podem abrir mão de tê-la.

\subsubsection{A formação continuada e a filosofia da práxis}

Nesse meu contato com as coordenadoras, percebi que cada uma delas de fato delineia, ou seja, planeja uma peculiar organização dos momentos da coordenação pedagógica. Cada uma, de maneira distinta, pensa os encontros nas coletivas das quartas feiras, o acompanhamento dos projetos que estão sendo desenvolvidos e a elaboração coletiva do planejamento com conteúdos e metodologias que atendam às necessidades de aprendizagem dos alunos.

No entanto, vivenciei e reconheci duas frentes ímpares em relação às ações das coordenadoras pedagógicas. Acredito que a constituição de cada uma como coordenadora pedagógica e sua trajetória tem influenciado fortemente suas ações, organização e a formação continuada empreendida por elas.

\footnotetext{
${ }^{8}$ PNAIC - Pacto Nacional pela Alfabetização na Idade Certa é de iniciativa federal assumindo o compromisso de assegurar que todas as crianças estejam alfabetizadas até os oito anos de idade, ao final do $3^{\circ}$ ano do ensino fundamental. Para isso tem oferecido formação e bolsa para os professores alfabetizadores.
} 
Uma delas, diante dos conflitos e das demandas que surgem todos os dias no “escasso" espaço escolar (CP 01, $1^{\circ}$ Questionário, Questão 8), afirma que não tem dificuldade para realizar a formação na escola, mas na prática, não apresentou uma organização do trabalho pedagógico que favorecesse as reflexões, teorizações e constituições didáticopolíticas (CURY, 1985).

Essa divergência em termos de intenções e atitudes é reforçada pela estrutura da escola que atende ao mesmo tempo e no mesmo espaço, às diferentes etapas da educação básica: anos iniciais, finais, ensino médio e educação infantil e apesar da consciência da necessidade de uma dinâmica diferenciada para os momentos de coordenação coletiva e da formação continuada dos professores de cada etapa do ensino, não vi uma proposta que favorecesse a reestruturação desses momentos.

A outra interlocutora apresenta uma clara organização do trabalho pedagógico a partir da consciência da sua constituição como coordenadora pedagógica. Constatei esse fato por meio da sua fala: "porque eu tenho buscado a minha constituição enquanto sujeito, sei da minha função dentro da escola" (entrevista). Desse modo, ela propõe estudos de vários artigos científicos, produz diversos materiais que possibilitam uma melhor organização não apenas do seu trabalho, mas também a organização do trabalho do professor em sala de aula e de atendimento aos alunos e desenvolve um trabalho no qual se reflete e teoriza a prática.

É importante destacar o valor desses momentos de reflexão, de teorização da prática e reconfiguração da prática a partir da teoria, porém não observei nas discussões realizadas o sentido de levar à reflexão para a transcendência consciente do trabalho educativo para além das questões da prática docente, uma discussão que refletisse as questões políticas características do trabalho educativo emancipador.

Tais indicadores mostram a necessidade da abertura, na UE 01, de um espaço de interlocução entre equipe gestora, coordenação pedagógica e grupo docente para identificar alguns fatores que tem impedido a realização da formação continuada nos espaços disponíveis. Outro ponto a ser considerado diz respeito à reflexão não apenas sobre a importância dessa formação, nem de acordo com os objetivos pelos quais a formação continuada docente foi posta para dentro do espaço escolar, mas transcender esses objetivos pensando nessa formação a partir da filosofia da práxis, na qual o professor estuda, analisa a sua realidade e se posiciona criticamente tornando reais as possibilidades de alavancar transformações na sociedade. 
Na UE 02, identifico a necessidade de encaminhar as reflexões na perspectiva de, teorizando as questões cotidianas, compreender as questões políticas intrínsecas ao trabalho do professor, pois segundo Saviani (2012), a reformulação do plano vivido deve ser tomada como ponto de partida para a elevação da consciência docente e do pensamento político, ou seja, a concretização da competência técnica e do compromisso político.

Sendo o coordenador, agente pedagógico, ele precisa pensar em estratégias que façam dos momentos de formação continuada, algo além da reflexão sobre a prática, pois ele "tem que saber dimensionar a função política da educação dentro de uma outra concepção de mundo, dada pela filosofia da práxis" (CURY, 1985, p. 114).

Entretanto, observei certa insegurança na fala da CP 01 ao se expressar sobre o referencial, o material que ela busca para embasar a formação continuada que ela realiza nos momentos da coordenação coletiva. Pela sua fala não fica claro se ela reconhece que é o movimento teórico-prático que deve subsidiar o seu trabalho de formação do professor e o trabalho do professor em sala de aula. Vejamos suas expressões a respeito da formação por ela implementada:

\footnotetext{
Sim, assim é... O grupo é bem entrosado [...] as professoras discutem muito, às vezes, até tem umas brigas aí, uma pensa de um jeito, uma pensa de outro, mas mesmo assim o grupo é muito coeso. E assim, elas são muito receptivas também. [...] Por exemplo, aquele curso dos Ciclos, no começo teve muita resistência, tinham muitos professores que não aceitavam, mas no decorrer do curso a gente foi discutindo e a coisa foi fluindo. Então, assim, a gente procura trazer coisas, artigos de revistas. A gente está tentando sempre melhorar nosso trabalho. (CP 01).
}

Dessa fala, é possível ver que apesar da formação docente ganhar materialidade baseando-se em cursos externos e artigos de revistas sem uma apropriação crítica das questões que subjazem o agir docente e sem um direcionamento epistemológico, segundo a CP 01, esta acredita que o grupo se envolve muito e tem colhido muitos frutos e afirma: "A gente vê assim, que os alunos em questão de disciplina, questão de conteúdo estão conseguindo trabalhar melhor". Contudo, tal encaminhamento não parece ser motivador do professor a ponto de provocá-lo a atuar de forma surpreendente, criativa e dialética com o novo na constituição da práxis.

A partir dessas expressões pude identificar alguns indicadores importantes que caracterizam as ações de formação continuada empreendidas pela CP 01 e, por conseguinte, a sua concepção de formação continuada docente e concepção do grupo. 
Quando, por exemplo, a coordenadora pedagógica menciona as brigas no grupo, a resistência e não aceitação do curso indica que não há discussão prévia a respeito do plano de formação que leve à reflexão sobre a importância dos momentos dessa formação no espaço/tempo da coordenação pedagógica.

Identifico, também, ser necessário abrir caminhos que levem à construção de uma relação de confiança pedagógica entre a coordenadora e o grupo, além de indicar a necessidade de se construir um espaço dialógico que incentive e fortaleça a participação crítica e criativa dos professores, não de resistência, mas de construção de estratégias para que diante de cursos vindos da SEEDF, o grupo seja autônomo para adaptá-lo às suas reais necessidades, ou seja, à sua realidade.

Nesse sentido, Christov (2010) afirma que nos espaços de formação continuada docente é natural que surjam opiniões divergentes, no entanto, é necessário enfatizar a participação de caráter mais político dos professores na elaboração dos processos de ensino, na constituição das relações entre os pares e na conscientização pela necessidade de realizar uma formação continuada que seja comprometida de fato com a técnica, mas, sobretudo, com a autonomia intelectual dos professores.

No sentido dessa constituição da práxis, a CP 02 demonstrou ter a consciência da importância da teoria além da prática, mas não consegui depreender das suas expressões a consciência de que esse movimento da práxis é fundamental para a formação da consciência da necessidade de transformação. Entretanto, sentir a necessidade do embasamento teórico para a ação docente é um indicador do início da mudança que a educação hoje necessita.

Reconhecendo a carência de um embasamento teórico afirma:

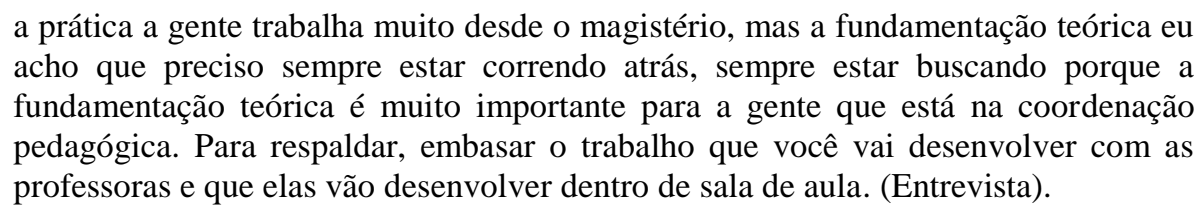

Como já discutido em capítulos anteriores, o trabalho docente se constitui na construção intelectual como foi observado pela CP 02, sendo importante ter nos momentos da coordenação pedagógica, espaço para estudar e refletir acerca das teorias educacionais de maneira que favoreça a criação de novas situações educativas e que tenha para o coletivo uma relevância social se concretizando na prática, transformando o agir, o fazer docente em si, a partir da transformação das concepções individuais e do coletivo a respeito dos objetivos da 
educação que vise transformar as relações sociais opressoras das classes populares (VÁZQUEZ, 1977).

Por isso, é muito importante que o coordenador busque atuar de maneira que possibilite a partir da prática fundamentada em uma teoria, superar a dicotomia entre trabalho manual e trabalho intelectual, entre o pensamento e a ação, entre teoria e prática na concretização da práxis (LOMBARDI; SAVIANI, 2008), considerando de fato, o seu trabalho no nível intelectual, no sentido de suscitar momentos para estudar e refletir acerca de teorias e ideias, de modo que possa criar situações que tenham relevância para a construção coletiva de novas concepções e novas práticas educativas.

\subsubsection{A formação continuada e o desafio de superar o trabalho individualizado}

Ainda buscando compreender as estratégias de formação continuada empreendidas pelas coordenadoras pedagógicas e a importância da práxis para o trabalho docente, questionei a CP 01 a respeito de pautas, portfólio, atas ou outros tipos de registros dos momentos formativos. Ela me mostrou um caderno que é preenchido quando ocorrem as coordenações coletivas no qual são registradas as pautas, as sugestões e as deliberações, com assinatura dos professores regentes presentes, da coordenadora e da direção (Anexo F).

Segundo a CP 01, a formação continuada docente na UE 01 é organizada através de uma pauta na qual são preenchidos os assuntos a serem discutidos, são levantadas sugestões e são registradas as deliberações do grupo (Questão 01 do $1^{\circ}$ Questionário Aberto).

Pela expressão das interlocutoras, ou seja, a CP 01 e a PR 10, é possível identificar a confirmação do que eu já havia observado, isto é, que as reuniões acontecem no sentido de buscar alternativas para atender demandas emergenciais. As ações e proposições de formação continuada da UE 01, aparentemente, já revelam as suas características.

Percebi a desarticulação no sentido de que os momentos coletivos não são articulados com estudo: currículo, letramento, projeto interventivo, avaliação formativa etc, ou seja, não tive evidências de que essa formação continuada seja um contributo real para que o fazer docente tenha impacto nos problemas de aprendizagem dos alunos e nem tão pouco que tenham repercussão nas questões educacionais e sociais mais amplas.

O espaço escolar é um lugar privilegiado para refletir a problemática educacional e a formação continuada docente deve considerar essa dinâmica para efetivar mudanças tendo 
as próprias demandas como material a ser discutido e trabalhado, tendo os professores como protagonistas dessas transformações (GOUVEIA; PLACCO, 2013).

Os problemas devem motivar não apenas reações a eles, mas principalmente iniciar um processo de organização do trabalho pedagógico que venha minimizá-los por meio de projetos preventivos, levando a ação do coletivo para além do projeto interventivo, colocando a escola na perspectiva de pensar uma teoria que seja guiada pela ação projetada pela equipe gestora, pelos coordenadores pedagógicos e docentes objetivando a transformação da sua realidade.

Analisando a perspectiva dos professores regentes da UE 01, mesmo com respostas positivas aos questionamentos sobre a importância da coordenação pedagógica e dos momentos de formação continuada, os professores, na prática, ainda não usufruem desse espaço e desse tempo de forma que atendam aos objetivos para o qual eles foram conquistados, considerando que nos encontros que observei não houve o momento da formação continuada e nem o planejamento das atividades do mês como expresso pela CP 01 .

De acordo com as Orientações Pedagógicas da SEEDF (2014) esse espaço/tempo da coordenação pedagógica deve estabelecer o seu plano de ação como sendo uma construção coletiva, devendo constar no PPP da escola e "sistematizar o espaço/tempo da coordenação pedagógica para o desenvolvimento e articulação do trabalho pedagógico e da formação continuada" (DISTRITO FEDERAL, 2014, p. 14).

Nessa perspectiva, identifiquei a ausência dessa dinâmica de articulação entre a formação continuada no espaço/tempo da coordenação pedagógica e o trabalho pedagógico coletivo na UE 01. Essa carência certamente tem culminado em um trabalho mais solitário, individualizado.

Tal desarticulação interfere no trabalho do professor como é possível constatar na fala de um dos professores regentes quando se refere à interferência do trabalho de formação continuada docente realizado no espaço/tempo da coordenação pedagógica. Ela, a PR 10 explicita essa desarticulação do trabalho na coordenação:

\footnotetext{
Tem interferido na minha prática, tendo em vista que venho de 11 anos de trabalho em escolas classes e estava bastante acostumada com o trabalho coletivo (tanto de planejamento do currículo e sua inserção nos projetos das escolas, bem como de formação continuada) e, estou me habituando ao trabalho mais individual que acontece aqui. (Questão 5 do $2^{\circ}$ Questionário).
}

A partir dessa fala, fica clara a falta de conexão na estrutura do trabalho do coordenador pedagógico, tornando-se um fator que interfere diretamente na atuação do 
professor. Sem uma organização que favoreça a construção coletiva, há o incentivo mesmo que não intencional, de práticas isoladas que não favorecem a reflexão e a crítica ao trabalho por eles realizado.

Nessa perspectiva, Cury (1985) afirma que o trabalho educativo enquanto não transcender a percepção individualizada se manterá dentro do processo hegemônico dominador confirmando e fortalecendo a ideologia da classe dominante pelo senso comum.

Como desafio, para que essa individualização do trabalho pedagógico não se sobreponha ao trabalho construído coletivamente e encaminhe o grupo à sua autonomia, o coordenador pedagógico, deve assumir responsabilidade de pensar estratégias de ação e de formação que fortaleçam esse trabalho, além de propor ações que favoreçam a superação da sua fragmentação.

Quando o trabalho pedagógico é pautado na individualização, como afirma a PR 10 da UE 01, ele segue na contramão da idealização da ampliação do espaço/tempo da coordenação pedagógica e das transformações sociais que tanto necessitamos.

Sendo assim, essa individualização insere o trabalho docente no rígido roteiro estabelecido pela classe dominante, levando a escola a perder cada dia mais seu valor e sua posição privilegiada de produtora e disseminadora de conhecimento sistematizado (FERNANDES, 2012), cabendo um posicionamento firme do coordenador pedagógico para que sejam resgatadas reflexões a respeito da função da escola e da importância do trabalho coletivo para a constituição da identidade da escola.

Muitas vezes, nas escolas da rede pública, o trabalho individualizado é confundido com autonomia, porém como já mencionado anteriormente, autonomia é um processo coletivo que se coloca a serviço de transformações das condições sociais de ensino. Logo, não tem nada a ver com práticas isoladas e desconectadas do coletivo (CONTRERAS, 2002).

\subsubsection{A formação continuada e a constituição da identidade das UE's}

Outro desafio que se apresenta ao coordenador pedagógico é o de organizar o trabalho de forma que possibilite reflexões a respeito das transformações que a escola necessita, não apenas reagir às dificuldades que surgem no cotidiano. Agir para construir. Construir a consciência de coletivo, a visão da coresponsabilidade do trabalho educativo, a 
identidade da escola, tendo um trabalho não ritualizado, mas que apresenta uma organização compartilhada, refletida, discutida e decidida por todos.

Vi que na UE 01 há uma organização, mas que essa organização não tem favorecido a ultrapassagem do nível de reação às demandas de uma escola grande com seus muitos problemas. Essa realidade é expressa na fala da CP 01 a respeito de como ela espera que seja a formação continuada no espaço escolar:

\begin{abstract}
Ah! A gente trabalha assim, procurando alcançar objetivos. Por exemplo, essa escola aqui como ela é muito cheia, tem coisas que a gente não consegue fazer por conta do espaço restrito. Por exemplo, trabalhar a psicomotricidade com alunos de primeiro ano você não consegue. Tem um pátio ali que se fizer barulho vai incomodar os outros alunos. Tem uma quadra que tem horários de quinta a oitava série e ensino médio. Claro! Tem que ter. Está na grade! Então, tem coisas que a gente tenta de alguma forma, mas nem sempre a gente consegue.
\end{abstract}

Como é possível observar na fala da CP 01, os objetivos levantados nos momentos de formação na UE 01, estão voltados para a organização, em princípio, das questões da prática em si - psicomotricidade. É claro que as questões da prática não são de menor importância, mas se tornam limitadas quando se restringem apenas ao fazer, tornando as ações intuitivas baseando-se em abstrações desarticuladas aos temas e conteúdos necessários à formação humana.

Considerando que a profissão docente é precipuamente intelectual, até para "saber-fazer" é necessário compreender a teoria que embasa esse saber impelindo o indivíduo a aprender baseando-se em conteúdos e habilidades que ligam a sua qualificação ao mercado de trabalho. Contudo, faz-se necessário também ultrapassar esse fim tendo a noção ampla do trabalho como princípio vital para a formação do ser social, sendo o homem capaz de transformar conscientemente a própria realidade (JIMENEZ; MAIA, 2013).

Sob essa ótica, o embasamento teórico, segundo Mello (1982), vai indicando a perspectiva do compromisso político, realizando a mediação da competência técnica e se constituindo em condição necessária, embora não suficiente, para a realização desse mesmo sentido político da prática docente para o professor. Esse movimento vai gerar transformações nas concepções e, por consequência, nas práticas dos professores.

Ainda com a intenção de compreender as perspectivas da organização dos momentos da formação continuada na coordenação pedagógica, perguntei de onde surgiam os temas a serem trabalhados, o roteiro por ela referenciado. A CP 01 afirmou: 
De onde surgem esses temas? Esse roteiro, principalmente de algumas questões que são levantadas pelos professores. Por exemplo, a gente está assim com um problema sério de agressividade. Os alunos estão muito agressivos, eles batem muito, então, a partir de temas assim a gente procura pontuar como é que a gente trabalha, como é que a gente faz em sala de aula. Eu entro na sala e converso com os alunos. A direção também é dessa forma.

Mais uma vez, como vemos no trecho acima, a interlocutora se refere a um problema já instaurado, confirmando assim, que o trabalho se organiza para responder às situações que surgem do cotidiano escolar - problema de indisciplina; ainda não na perspectiva preventiva de superar o possível caráter fragmentário das práticas educacionais características do atual sistema e as questões subjacentes a essa lógica e que provavelmente favorecem não apenas o problema de indisciplina, mas o da não aprendizagem, da evasão e tantos outros problemas tão presentes nas escolas da atualidade.

Reforçando essa caracterização da dinâmica que acontece no espaço/tempo na UE 01, a PR 03, afirmou que em termos práticos, "durante as reuniões ocorre às vezes, preenchimento de formulários ou resposta a questionamentos" e a PR 10 afirmou que ela sempre participa das reuniões e leva proposições "apesar de as reuniões terem sido, em sua maioria, para passar informes".

Na UE 02, tanto pela fala dos interlocutores como pelo que vi nos momentos de observação, há um trabalho na perspectiva preventiva além da perspectiva interventiva na qual o trabalho coletivo favorece essa construção como afirma a CP 02:

\footnotetext{
A gente se organiza pedagogicamente de maneira a nortear o trabalho do professor de forma unificada, mesmo existindo as diferenças de atuação de cada um. Com esse trabalho colaborativo a gente consegue pensar e criar estratégias pedagógicas que realmente possibilitem um trabalho diferenciado que evite que muitos alunos necessitem do reforço, de participar do projeto interventivo. A gente pensa em evitar o incêndio e não apagar o fogo! (risos). (Entrevista).
}

Considerando os três níveis de atuação do coordenador pedagógico: "1) resolução dos problemas instaurados; 2) prevenção de situações problemáticas previsíveis; 3) promoção de situações saudáveis do ponto de vista educativo e socioafetivo" (VILLELA; GUIMARÃES, 2010, p. 59), é possível perceber com clareza o nível no qual se encontra o trabalho em cada UE. A UE 01, ainda trabalha na perspectiva de resolver os problemas instaurados enquanto que a UE 02 já transita entre a prevenção de problemas e a promoção de situações saudáveis.

O grande problema de se manter no nível 01, é que o potencial de trabalho tanto dos professores como dos coordenadores fica subsumido aos problemas cotidianos não 
favorecendo a articulação do coletivo no alcance das metas estabelecidas pelo próprio coletivo e registradas no PPP da escola, fator que dificulta o amadurecimento do grupo e a constituição da sua identidade.

Compreendo que os três níveis de atuação são necessários e até fundamentais para a constituição do trabalho do coordenador pedagógico, mas a CP 01 e a CP 02 precisam ficar alertas, pois o trabalho que se mantém no nível 1, de modo a "correr atrás do prejuízo" trará muito desgaste à figura do coordenador pedagógico e prejuízo ao trabalho e ao crescimento do grupo, principalmente em trilhar caminhos participativos de consciência crítica e de luta pela construção de uma escola melhor (VEIGA; QUIXADÁ VIANA, 2012, p. 25).

Dessa forma, apesar de a escola apresentar necessidades urgentes, mais uma vez destaco a importância do planejamento e da organização intencional do trabalho pedagógico estabelecendo metas a serem alcançadas, estratégias a serem utilizadas para que o trabalho tenha fundamentação teórico-metodológica e saia do nível incidental de concretização do PPP.

\subsubsection{A formação continuada e o desafio da organização do trabalho pedagógico}

Trabalhando no sentido de superar algumas dificuldades que se apresentam na UE 02, a CP 02 organizou o espaço e o tempo da coordenação pedagógica coletiva em momentos e criou alguns instrumentos para auxiliar as professoras na organização do seu trabalho em sala de aula.

Segundo ela, esse material facilita a organização do professor e possibilita a reflexão sobre a própria prática, permitindo inclusive que o professor consiga enxergar as lacunas na própria formação e busque a sua autoformação (entrevista).

Sobre a organização das quartas-feiras afirma:

Para quarta-feira, eu sempre me organizo na segunda-feira. É o dia que eu estou na escola o dia todo. A gente constrói uma pauta para ser debatida nesse dia e nessa pauta eu procuro colocar tudo que vai ser importante para ser trabalhado. (Entrevista).

A partir da fala da CP 02 é possível observar que ela planeja e organiza antecipadamente sua ação e ainda estabelece prioridades. Como visto anteriormente, essa organização é importante para o reconhecimento do trabalho do coordenador pelo grupo. 
Sobre a organização dos momentos de planejamento coletivo ela afirma que procura "não transformar o momento da coordenação coletiva num momento mais administrativo, pois ele tem que ser extremamente pedagógico" (CP 01, Entrevista). Começa o dia repassando informações importantes e já parte para o planejamento utilizando o currículo, se organizando dentro de um quadro (Anexo A) criado pelas coordenadoras anteriores, mas adaptado por ela de acordo com novas necessidades apontadas pelo grupo.

Ela também menciona outras adaptações realizadas a partir das necessidades que foram surgindo:

Em princípio a gente desenvolvia para um mês, escolhia os quatro textos para serem trabalhados semanalmente e escolhia o gênero textual para ser trabalhado. Mas agora a gente tem trabalhado por semana. Então, por semana a gente escolhe o texto e em cima desse texto base, de acordo com o currículo e com o que foi definido, a gente busca trabalhar coletivamente com a escola toda. Quando a gente termina o planejamento que é semanal, a gente sempre pergunta para o professor qual é a demanda, o que eles precisam de ajuda dentro da sala de aula. (Entrevista).

Essa capacidade de perceber as necessidades que surgem, tendo a visão de que o cotidiano se modifica e com essas modificações novas demandas surgem é imprescindível para o coordenador pedagógico, pois transcende a cristalização de ações que não atendem mais às necessidades de aprendizagem tanto dos docentes como dos discentes e acaba por impulsionar a reconfiguração das práticas dos professores.

Na UE 02, além da divisão em momentos do espaço e do tempo da coordenação pedagógica coletiva e de ter este quadro, e outros (Anexos B, C, D e E), para organizar o planejamento com as professoras, a CP 02 traz as demandas anotadas em um grosso caderno para organizar suas ações de forma mais efetiva. Segundo ela, a demanda da coordenação é muito grande, por isso teve que criar estratégias de organização para dar conta. Sobre essas demandas relata:

Temos uma demanda muito grande porque aqui na escola a gente está com o projeto de leitura. [...] Tem a parte da formação individual mesmo das professoras, tem professora nova chegando e a gente tem que fazer a formação individual com elas. Tem o planejamento coletivo que a gente também tem que se preparar para esse momento, tem o Projeto Trilhas ${ }^{9}$ que vai começar no segundo semestre e assim, tem que ter uma preparação, tem que ter uma organização de como isso vai se dar, tem a questão da matemática que a gente tem que organizar, é muita demanda. (Entrevista).

\footnotetext{
${ }^{9}$ É um projeto idealizado pela Natura (empresa de cosméticos) que disponibiliza um conjunto de materiais: cadernos de orientação ao professor, jogos educativos, cartelas para atividades, além de diversos títulos literários. Esses materiais, segundo a própria empresa, foram elaborados para instrumentalizar e apoiar o trabalho docente no campo da leitura, escrita e oralidade.
} 
E explica que procura se organizar por dia, o que tem de imediato para realizar ou resolver, eliminando da lista aquilo que foi realizado e retomando no dia seguinte o que não deu conta de realizar.

Seguindo as expressões abaixo é possível observar que sua atuação não se restringe aos problemas imediatos oriundos do cotidiano escolar e nem às demandas apenas dos docentes. Sua atuação é ampla e por isso necessita de organização.

\begin{abstract}
Assim, a gente tenta atender a demanda dos alunos com dificuldade de aprendizagem, a demanda do professor com o acompanhamento do planejamento, currículo, saber como estão as atividades em sala de aula, os momentos culturais. É muita coisa para fazer e a gente tem que se organizar. Assim, é... diariamente mesmo, não tem como eu planejar coisas para daqui a um mês, tudo nosso é planejado. [...] todo mês a gente tem que sentar com o monitor, avaliar os meninos que estão no projeto, [...] conversar com os professores, fazer a formação dos monitores também porque eles não tem essa formação, é assim, bem dinâmico mesmo. Tem dia que a gente não para para nada (risos). (Entrevista).
\end{abstract}

De fato, com uma dinâmica de organização que ela criada pela CP 02, ela consegue não ficar restrita ao atendimento das demandas emergenciais da escola, mas organiza tempos e espaços formativos na escola como foi observado a partir do seu relato, em uma perspectiva de confirmação da identidade da UE.

Esse movimento de refletir tanto sobre as necessidades emergenciais como sobre projetos e demandas futuras favorece o que foi visto anteriormente, a promoção de situações saudáveis do ponto educativo e socioafetivo tanto dos docentes como dos discentes. Essa é uma postura formadora que possibilita, também, a organização do trabalho pedagógico dos professores.

Como formadora, a CP 02 percebe que sua atuação já gerou mudanças na postura das professoras. Certamente ela reconhece e é reconhecida no seu espaço de atuação como autoridade nos assuntos pedagógicos e contribuiu para a construção da autonomia docente. Sobre esse tema ela afirma:

[...] hoje eu percebo que as meninas tem uma rotina pedagógica muito focada. Quando elas vão fazer um trabalho, elas sempre vão ao currículo para se apoiar. Se tem algum conteúdo ou coisa que elas não entendem, buscam informações em outras fontes. Eu acho que eu, como coordenadora, contribuí em algum momento para isso. (Entrevista). 
Sem dúvida, essa rotina pedagógica vivenciada pelas professoras que a CP 02 se refere, é fruto de uma rotina estabelecida por ela na organização do trabalho pedagógico da escola. Realidade explicitada na fala a seguir:

É fato que na quarta-feira é um momento que todo mundo sabe que aquele é o momento de planejar. Ninguém leva nada para fazer lá, todo mundo tem consciência de que aquele momento é o momento de formação, é o momento para a gente poder se fortalecer pedagogicamente na escola. Então, assim, a gente está se constituindo nesse processo. (Entrevista).

Ao analisar os valores manifestados nesses trechos, pude identificar que os interesses individuais da CP 02 em agir como sujeito na coordenação pedagógica geram envolvimento do coletivo docente. Ela busca, a partir de suas ações, construir, elaborar experiências significativas de formação continuada no espaço escolar, gerando transformações no comportamento dos professores e, por consequência, gerando qualidade nas relações entre os pares e no desempenho da função de cada um naquele espaço que configuram seus espaços sociais.

A busca por desempenhar bem a sua função de coordenadora pedagógica é um elemento relevante para o seu crescimento intelectual e essa hipótese não diz respeito apenas à $\mathrm{CP}$ 02, pois reflete a constituição da competência técnica e política do coletivo da escola (SAVIANI, 2012). É possível constatar isso na expressão de um dos professores regentes e da professora da sala de recursos:

\footnotetext{
A formação continuada aqui na escola tem nos levado a estar em contato constante com diversas concepções, experiências e realidade que possibilitam o nosso aprendizado, suprindo assim carências na nossa formação e ajudando-nos a lidar com determinadas dificuldades. Ela tem sido extremamente rica. Tenho aprendido muito, estou construindo uma postura nova. (PR 02, Complemento de frase 02).

O coordenador está ciente da importância do seu trabalho e é agregador, sabe realizar as mudanças que o grupo no momento almeja sem perder o objetivo da sua função. (PSR, $1^{\circ}$ Questionário aberto).
}

Estabelecer essa organização do trabalho pedagógico que dá forma à identidade da escola não é um trabalho simples. A CP 02 define que o caminhar na coordenação pedagógica é árduo, contudo sugere opções buscando se posicionar no contexto de sua função:

Olha, a dinâmica da atuação do coordenador pedagógico é intensa, porque aqui a gente trabalha desde o atendimento pedagógico ao professor, atende inclusive problema de indisciplina e atendimento a pais. A gente também está sem a pedagoga, então assim, quando tem algum problema envolvendo família, aluno, a gente faz esse atendimento, a gente faz atendimento individual, quando a professora 
precisa da gente para fazer intervenção na sala, a gente faz, o planejamento também é acompanhado. Eu acho que sou bem dinâmica (risos). (Entrevista).

É importante atentar para o fato de que a CP 02 mostra ser capaz de gerar mudanças no próprio espaço de atuação, focando seu olhar nas possibilidades e não nas dificuldades, mantendo e legitimando seu valor mesmo diante das contradições e confrontações tão características da dinâmica complexa do espaço escolar.

Para a CP 02, mesmo com toda a problemática da coordenação pedagógica, os problemas não são vistos como obstáculo, mas como estímulo para construir ações que modifiquem a sua realidade e como possibilidade de assumir um novo posicionamento como coordenadora pedagógica.

Com isso, a CP 02 apresenta um indicador de que transcende as incertezas, as possíveis frustrações e os conflitos que são próprios da dinâmica escolar, evidenciando que é capaz de estruturar e reestruturar o seu campo de ação, privilegiando um constante reelaborar de sua prática.

Desse modo, é possível perceber, de acordo com as ideias de Souza e Placco (2010), que a função do coordenador pedagógico é nova, mas traz em si concepções e referenciais que se articulam pela necessidade da consolidação da organização do trabalho do coordenador pedagógico como base para a organização do professor em sala de aula e essa organização de ambos, coordenador pedagógico e professor regente deve ter como objetivo a formação humana.

Sabe-se que há, na educação, a demanda por uma atuação do homem sobre a realidade objetiva em uma perspectiva da totalidade, do combate à fragmentação das ações sobre essa mesma realidade. Face de tais urgências, Saviani (1994) aponta para uma formação em torno da omnilateralidade, uma formação em que o homem seja capaz de se colocar na condição ampla de disponibilidade para saber, gostar, conhecer coisas, pessoas e realidades diversas. Representando uma formação mais ampla, mais avançada, na construção do homem omnilateral, criando novas bases sociais que permitam desenvolvimento das potencialidades humanas.

Embora não se encontre em Marx a sua precisa definição, é possível compreender a omnilateralidade a partir de suas obras, as quais nos remetem à compreensão da necessidade da ruptura ampla e radical com o homem limitado da sociedade capitalista sendo expressiva no que diz respeito à ética, tanto no fazer prático quanto na criação intelectual (SOUZA JUNIOR, 1999). 
Essa ruptura com o modelo da unilateralidade, característico da atual sociedade, não significa que gênios serão formados, mas homens capazes de se reconhecerem sujeitos históricos e sociais e que compreendem a importância da superação da dicotomia trabalho manual/intelectual em especial, superar a mesquinhez, os preconceitos e o individualismo da vida social da burguesia (SOUZA JUNIOR, 1999).

Para tanto, o trabalho pedagógico deve ser organizado para superar o processo de fragmentação do fazer docente facilitando o acesso e a participação do professor na organização da gestão, tanto no âmbito pedagógico como no âmbito administrativo, colocando-o em condição de ver as contradições do mundo moderno e questioná-las buscando a superação.

Essa superação da fragmentação da educação e da divisão do trabalho será fundamental para a formação de indivíduos não mais limitados, mas indivíduos que reconhecem no seu trabalho e na ampla coletividade as dimensões humanas: "ética, afetiva, moral, estética, sensorial, intelectual, prática; no plano dos gostos, dos prazeres, das aptidões, das habilidades, dos valores etc., que serão propriedades da formação humana em geral, desenvolvidas socialmente" (SOUZA JUNIOR, 1999, p. 110).

Por fim, é possível afirmar que nas duas UE's pesquisadas identifico o desafio de organizar o trabalho pedagógico de maneira que ele venha a superar o atendimento de demandas meramente formais, a fragmentação do ensino, a separação do trabalho manual do intelectual na constituição da práxis e se colocar a serviço de reflexões que valorizem o espaço/tempo da coordenação pedagógica, a figura do coordenador pedagógico e busque a consolidação da formação continuada docente na perspectiva de formar para a crítica, formar para romper com os grilhões do capitalismo, formar para emancipar os indivíduos transformando radicalmente a sociedade contemporânea. 


\section{A CHEGADA... REFLEXÕES SOBRE OS ACHADOS NO CAMINHO}

Com a análise dos achados empíricos na senda da compreensão da formação continuada docente no espaço/tempo da coordenação pedagógica, busquei resgatar o movimento histórico da coordenação pedagógica, da figura do coordenador pedagógico, do trabalho e da formação docente, tendo como finalidade compreender, de forma ampla, como o social e o educacional são indissociáveis apesar das tentativas do sistema atual em dicotomizá-los.

Minha pesquisa teve como objetivo central analisar a proposta de formação continuada docente desenvolvida pelos coordenadores pedagógicos locais no espaço/tempo da coordenação pedagógica e sua contribuição para a formação dos professores dos anos iniciais.

Não tive a pretensão de esgotar, nesse trabalho, as possibilidades de interpretação e desvelamento sobre o tema investigado, apenas busquei levantar alguns aspectos relevantes a respeito da formação continuada docente e, dessa forma, apontar para a necessidade de valorizar e aprofundar, cada vez mais, as discussões sobre o tema da formação continuada docente no espaço/tempo da coordenação pedagógica nas escolas públicas do DF dentro desse próprio espaço.

Busquei realizar a leitura do contexto da coordenação pedagógica no Brasil, desde o princípio até a atualidade, apontando questões que são frutos das determinações da sociedade moderna e sua necessidade de se fortalecer através da educação institucionalizada, ou seja, ofertada nas escolas.

Ao longo dessa discussão, considero que tive a oportunidade de responder não apenas a questão central da pesquisa, mas de igual modo, as questões subjacentes que favoreceram a compreensão das concepções e ações das coordenadoras pedagógicas nas duas escolas da rede pública do Distrito Federal, no que diz respeito à formação continuada docente implementada por elas.

As informações levantadas a partir das expressões dos interlocutores participantes da pesquisa retrataram o caráter histórico e social da educação, evidenciando que apesar de o trabalho docente pela lógica do capital estar sendo constituído na perspectiva das competências tendendo reforçar a ideia de prática pedagógica fragmentada e descontextualizada, há o reconhecimento do trabalho do professor como intelectual, pois pressupondo reflexão, análises, ações e reconfiguração de ações apresentando objetivos a serem atingidos, extrapola o nível prático reprodutivo. 
Nesse processo de pesquisa e análise, me deparei com concepções que variam desde uma ação reativa às demandas do cotidiano e desconectada do caráter formativo da função de coordenar, até uma ação pró-ativa com a atuação de um profissional que sabe tomar posicionamento e que procura ser coerente com essa posição.

Tal postura favorece a tomada de consciência de que a formação continuada faz parte do processo pedagógico interativo e dialético em que o maior beneficiado é o aluno, mas que na verdade, todos aprendem de forma processual e contínua no dia a dia tendo objetivos mais amplos do que pensar na prática pela prática.

O caminho percorrido, na busca por compreender o percurso histórico da constituição e do desenvolvimento da coordenação pedagógica e da formação continuada docente que acontece nesse espaço e tempo, me possibilitou compreender alguns aspectos do cenário educacional mais amplo, isto é, ver a escola como parte de um projeto de desenvolvimento da sociedade, bem como fundamentar algumas considerações sobre a relevante função da formação continuada docente no espaço/tempo da coordenação pedagógica como possibilidade emancipadora.

Nesse trajeto, ficou clara a importância de reconhecer o trabalho como princípio educativo, processo no qual o trabalho se constitui atividade primeira da mediação homemmundo. E de igual modo, reconhecer o trabalho de formação docente como um trabalho de educação das consciências, tendo a possibilidade concreta de formar o indivíduo para ser sujeito da sua história de forma ampla, no sentido de ir se constituindo enquanto ser humano na perspectiva da omnilateralidade rompendo com a limitação da formação fragmentária preconizada pela sociedade capitalista.

Vi que aparentemente, a falta de estrutura física das escolas se constitui em fator prejudicial ao desenvolvimento do trabalho docente, mas que na essência há a desvalorização e a precarização do trabalho educativo em muitos momentos explicitados nas expressões dos interlocutores. É a hipertrofia da escola que tem interposto barreiras à educação, tanto pela quantidade de novas atribuições quanto pelo tamanho da responsabilidade que é imposta aos professores para a concretização de uma educação de qualidade na ótica hegemônica.

Nessa frenética dinâmica, muitos são os professores que não enxergam as questões que subjazem a essas novas exigências, mas que podem ser trazidas à luz por meio da concretização da formação continuada que objetive analisar o contexto educacional, a função da escola, as ideologias que ditam as diretrizes educacionais na atualidade e as práticas das coordenadoras. 
Isso significa reconhecer, que as ações docentes implicam no desenvolvimento desse olhar crítico para que as determinações do sistema e a imposição de realizar a formação para sujeitar a profissão às imposições do mercado sejam superadas. É imprescindível que os professores vejam as possibilidades que a educação escolar traz de emancipação por meio da formação humana. Todavia, por meio das suas práticas e de seus discursos consegui enxergar a concepção que cada um traz da função social da escola e é fato que ainda temos um árduo caminho para que essa conscientização crítica seja disseminada e consolidada.

A análise das expressões dos interlocutores me remeteram à importância de compreender o trabalho docente como intelectual e a importância do não esvaziamento da sua prática embasando-a teoricamente na constituição da práxis, pois acredito que fundamentando o trabalho na filosofia da práxis, mesmo em um contexto de contradições, será possível trilhar um caminho no combate à lógica hegemônica. Compreender essa lógica que rege o mundo possibilita o entendimento das relações que se estabelecem no espaço escolar e buscar caminhos para superá-la.

A práxis é a ação transformadora que deve ser nutrida e sustentada pelo conhecimento da realidade indo ao encontro da mobilização de esforços para que a reflexão das questões do cotidiano escolar não seja baseada nas superficialidades, mas que venha a fortalecer o sentido histórico da ação educativa como formadora do homem e transformadora da sociedade.

É nesse contexto que surge a figura do coordenador pedagógico, não como o "salvador da pátria", mas como colaborador do trabalho docente, com a responsabilidade de realizar a formação continuada dentro da escola, organizar o trabalho pedagógico, suscitar reflexões na perspectiva de desenvolver ações que venham trazer transformações ao trabalho docente e por consequência favorecer a aprendizagem e o desenvolvimento social dos alunos.

Analisando as expressões dos interlocutores, pude perceber que são muitas as questões que desafiam o trabalho do coordenador principalmente no que diz respeito à necessidade de ele assumir a formação continuada no espaço/tempo da coordenação pedagógica.

É a partir da consciência ampla e clara do trabalho como princípio educativo, como princípio fundamental para a formação do ser social que o coordenador pedagógico compreenderá o trabalho pedagógico como princípio formativo docente desenvolvendo um trabalho que favoreça a transformação consciente da própria realidade. 
Ao conhecer as condicionantes da educação nos marcos do capital, obstante suas dificuldades, o coordenador pedagógico terá a possibilidade de buscar por alternativas concretas para que o seu trabalho de formação continuada docente se encaminhe para a construção da relação concreta do trabalho docente e a sua finalidade social.

Conforme explicitei em momentos anteriores os dados trouxeram à luz dinâmicas peculiares revelando as singularidades de cada unidade escolar, mas também deixaram claro que no contexto escolar diariamente haverá situações desafiadoras que podem se constituir como barreiras ou como propulsoras da crítica e de saltos qualitativos no desenvolvimento do trabalho educativo.

Como visto, respeitando as especificidades de ambas as unidades escolares, emergiram do contexto, vários desafios:

- reorganizar a prática pedagógica diante do fenômeno da hipertrofia da escola, materializada nas limitações da estrutura física;

- organizar o trabalho pedagógico de forma que venha a superar a fragmentação do trabalho docente;

- superar o trabalho individualizado;

- construir a identidade da escola;

- fortalecer o espaço e o tempo da coordenação pedagógica;

- fortalecer a formação continuada docente no espaço/tempo da coordenação pedagógica;

- fortalecer a formação do coordenador pedagógico;

- reconhecer a importância do coordenador pedagógico para a superação dos desafios citados, entre tantos outros desafios que surgem cotidianamente no chão da escola.

Frente a essa realidade, reforço a importância da formação continuada docente no espaço/tempo da coordenação pedagógica como detentora de grande potencial para fomentar discussões, reflexões críticas ao atual sistema educacional fundamentado nos marcos do capital, para superar entraves que ainda se interpõem à educação para a autonomia, na luta pela emancipação humana.

O espaço escolar se constituiu em espaço para construção e disseminação de conhecimento científico, logo sua utilização não pode ser negligenciada para que o trabalho 
nesse espaço favoreça o desenvolvimento pedagógico, o desenvolvimento docente e o desenvolvimento de posturas que busquem transformar o contexto social.

A coordenação pedagógica estruturada para ser desenvolvida pelos coordenadores pedagógicos por meio de ações conscientes e refletidas, tem possibilidade de fomentar discussões que levem o coletivo também a refletir sobre a própria prática, sobre as políticas educacionais, sobre currículo, sobre questões sociais que interferem o cotidiano escolar etc., motivando a ação pedagógica intencional e coletiva, ampliando a visão das relações que se constituem no espaço escolar, resultando em uma prática que vise o ensino e que esse esteja efetivamente a serviço das classes menos favorecidas.

Ela deverá ser sistematizada de forma que permita suscitar reflexões e discussões coletivas permitindo aos professores que compartilhem experiências e conhecimentos, possibilitando o avanço das práticas pedagógicas, engajamento de todos na organização do trabalho e construção na viabilização dos projetos a serem desenvolvidos por eles no decorrer do ano letivo, bem como a superação de tensão que surge naturalmente no ambiente escolar, principalmente no que diz respeito ao trabalho individualizado.

Acredito que os coordenadores pedagógicos devem desenvolver um olhar atento do coletivo da escola, para que se constituam como sujeitos de suas práticas na medida em que são capazes de desenvolver ações e posturas específicas ao ato de coordenar, o que dificilmente acontecerá sem que eles planejem e participem de forma ativa e crítica das atividades pedagógicas. Ou seja, na qualidade de sujeito, os coordenadores pedagógicos devem se posicionar dentro dos diferentes espaços no qual atuam, trazendo suas experiências pessoais, profissionais e sociais, gerando constantemente novas possibilidades de ensino e de aprendizagem.

Quando o coordenador pedagógico se posiciona como um intelectual que pensa sua prática, aliada a uma fundamentação teórica, este consegue mobilizar mudanças, assumindo-se como um profissional em constante formação, consciente de que tem de enfrentar desafios para formar professores autônomos e que vem a atuar de forma que transcenda a racionalidade técnica, pois tenho a clareza que, se por um lado o capital investe pesado com discursos e ações na intenção de cooptar os professores, por outro lado, vê-se o fortalecimento da luta pela formação docente como possibilidade de emancipação.

Compreendo que o espaço/tempo da coordenação pedagógica é um espaço privilegiado para dar suporte multidimensional ao trabalho pedagógico, portanto é um espaço 
coletivo, de responsabilidades compartilhadas e, portanto, deve ser compreendido e valorizado pelos professores.

A formação continuada docente no espaço/tempo da coordenação pedagógica tem potencial para desenvolver o olhar crítico do professor tendo o coordenador pedagógico como parceiro e não como a figura que cerceia pensamentos e que controla as ações docentes.

Essa formação deve ser baseada no diálogo, na articulação teoria e prática, no ensino, na aprendizagem, na avaliação e na transformação tanto de práticas como de concepções a partir do movimento dialético entre trabalho, formação, transformação, escola e realidade social.

Antes de encerrar, gostaria de deixar registrado um ponto para mim muito intrigante, pois apesar de no Regimento Escolar das Instituições Educacionais da Rede Pública de Ensino do DF, nos seus artigos 22 e 23, ser feita a referência à corresponsabilidade da atuação nas escolas ser da coordenação local, intermediária e central, CP 01 e CP 02 em nenhum momento da pesquisa fizeram referência à atuação ou à parceria com a estas coordenações. Por quê?

Pude depreender pelas conversas com os Professores Regentes, com as Coordenadoras Pedagógicas e com as Diretoras, que apesar do item IV do documento dizer que o papel coordenador intermediário é: “acompanhar e avaliar, junto ao coordenador da instituição educacional, o processo pedagógico" (DISTRITO FEDERAL, 2009, p. 22), há instaurada a visão de que a coordenação intermediária tem a função de vigiar o trabalho nas escolas e não de colaborar com o trabalho da coordenação local e que o coordenador intermediário está a serviço da CRE com a função de relatar falhas e não de colaborar com trabalho pedagógico das unidades escolares.

Vejo que esse também é um ponto importante a ser refletido nos momentos da coordenação pedagógica coletiva. Compreender que a coordenação em todos os níveis - local, intermediário e central, estão a serviço da educação e que o trabalho de coordenar não pode ser estanque. Tal compreensão será essencial para a constituição do trabalho de formação continuada docente seja realizado na perspectiva da transcendência de se pensar apenas nas questões da prática docente.

A compreensão da responsabilidade compartilhada entre coordenação local, coordenação intermediária e coordenação central será fundamental para que o trabalho realizado pelos coordenadores, em todos os níveis, se dê na perspectiva de fortalecer o 
trabalho colaborativo à partir das reais demandas sociais e constitua o coletivo da Coordenação Regional de Ensino que aos poucos constituirá a sua identidade em nível macro.

Para tanto, fundamental que o coletivo docente saia em busca de possibilidades de trabalhar para transformar não apenas a prática pedagógica, mas a dimensão social que está para além dos muros da escola, que se constitui e é constituída pelos gestores, coordenadores, professores, servidores em geral, alunos, enfim por cada um que está envolvido e é comprometido com o processo educativo.

De fato, a formação continuada docente no próprio espaço escolar, sua dinâmica, sua função, pode ser contraditoriamente espaço de aceitação do que está posto ou de luta, de resistência ou de desistência, de alienação ou de emancipação e o momento em que o professor desenvolver essa visão será o divisor de águas do fenômeno educacional e principalmente social tornando os homens capazes de romper com a ideologia dominante estruturando uma nova ordem social onde não haja mais explorados e exploradores, mas que haja entre os indivíduos e o gênero humano uma relação de enriquecimento mútuo (LESSA e TONET, 2008).

Espero sinceramente, com essa pesquisa, ter contribuído para gerar reflexões a respeito da formação continuada docente dentro do espaço escolar e a importância do espaço/tempo da coordenação pedagógica como lugar privilegiado para o fortalecimento dessa formação e para a construção de conhecimento.

Realizar esta pesquisa foi para mim, caminhar em lugares aparentemente conhecidos, mas de forma diferente, o que me possibilitou ver com outro olhar o que nem sempre está nítido quando fazemos parte do contexto. Tive também a oportunidade de enxergar o outro não como ser já constituído, mas como indivíduo de possibilidades e também exercitar o "estar no lugar do outro".

Ainda são muitas as questões que me inquietam a respeito da formação continuada docente no espaço/tempo da coordenação pedagógica, suas possibilidades e limitações e dos atores que ali agem e interagem, mas serão justamente elas, que também me impulsionarão a trabalhar para além das determinações de uma educação estruturada nos marcos do capital.

Sem dúvida, realizar esta pesquisa ampliou meu olhar sobre a importância da formação continuada docente, fortaleceu o meu lado professora/coordenadora e me instigou a não querer parar... 
Não! Quero seguir nesse caminho, ampliar minhas fronteiras nesse campo fértil que é a formação continuada docente e reafirmar a minha condição de sujeito, ser social, aprendente, me constituindo enquanto vou fazendo o meu caminho... 


\section{REFERÊNCIAS}

ALMEIDA, L. R.; PLACCO, V. M. N. S. O coordenador pedagógico e a formação centrada na escola. São Paulo: Loyola, 2013.

$\overline{\text { Loyola, }} ; \overline{2010 .}$ . O coordenador pedagógico e o atendimento à diversidade. São Paulo:

; _ـ O coordenador pedagógico e questões da contemporaneidade. São Paulo:

Loyola, 2011.

ALVES-MAZZOTTI, Alda Judith; GEWANDSZNAJDER, Fernando. O método nas ciências naturais e sociais: pesquisa quantitativa e qualitativa. São Paulo: Pioneira, 2000.

ANDRÉ, Marli Eliza Dalmazo Afonso de; VIEIRA, Marli M. da Silva. O coordenador pedagógico e a questão dos saberes. In: ALMEIDA, Laurinda Ramalho de; PLACCO, Vera Nigro de Souza. O coordenador pedagógico e questões da contemporaneidade. São Paulo: Loyola, 2010. p. 11-24.

ANTUNES, R. Adeus ao trabalho?: Ensaio sobre as metamorfoses e a centralidade do mundo do trabalho. São Paulo: Cortez, 2010.

ARAÚJO, Catarina Pereira de; MUNDIM, Elisângela Duarte Almeida. Coordenação pedagógica como política pública facilitadora de formação de professores. In: SOUSA, José Vieira de. Políticas de educação no Distrito Federal: evoluções e perspectivas. Brasília: Faculdade de Educação/Universidade de Brasília; Liber Livro, 2012.

BARDIN, Laurence. Análise de conteúdo. Lisboa: Edições 70, 2011.

BOGDAN, Robert; BIKLEN, Sari. Investigação qualitativa em educação: uma introdução à teoria e aos métodos. Porto: Porto Editora, 1994.

BRASIL. Decreto ${ }^{\circ}$ 19.890, de 18 de abril de 1931. Dispõe sobre a organização do ensino secundário. Diário Oficial da União, Poder Executivo, Brasília, DF, 01 maio 1931. p. 6945. Retificada em 03 maio 1931. Republicada em 04 jun. 1931. Disponível em:

<http://www2.camara.leg.br/legin/fed/decret/1930-1939/decreto-19890-18-abril-1931-

504631-norma-pe.html>. Acesso em: 12 nov. 2013.

Decreto-Lei 4.244, de 09 de abril de 1942. Lei Orgânica do ensino secundário.

Diário Oficial da União, Poder Executivo, Brasília, DF, 10 abr. 1942. Seção 1, p. 5798.

Disponível em: <http://www2.camara.leg.br/legin/fed/declei/1940-1949/decreto-lei-4244-9abril-1942-414155-publicacaooriginal-1-pe.html>. Acesso em: 12 nov. 2013.

Lei do Império. Lei de 15 de outubro de 1827. Manda criar escolas de primeiras letras em todas as cidades, vilas e lugares mais populosos do Império. C. L. do Império do Brasil, Poder Legislativo, Rio de Janeiro, RJ, 15 out. 1827. 
Lei $\mathrm{n}^{\circ} 5.692$, de 11 de agosto de 1971. Fixa diretrizes e bases para o ensino de $1^{\circ}$ e $2^{\circ}$ graus, e dá outras providências. Diário Oficial da União, Poder Executivo, Brasília, DF, 12 ago. 1971.

Lei n ${ }^{\circ}$ 9.394, de 20 de dezembro de 1996. Estabelece as diretrizes e bases da educação nacional. Diário Oficial da União, Poder Executivo, Brasília, DF, 23 dez. 1996.

. Ministério da Educação e Cultura. Secretaria de Educação Fundamental. Referenciais para formação de professores. Brasília, 1999.

Projeto de Lei $n^{\circ}$ 4.106, de 30 de agosto de 2012. Regulamenta o exercício da profissão de Supervisor Educacional, e dá outras providências. 2012. Disponível em: $<$ http://www.camara.gov.br/proposicoesWeb/prop_mostrarintegra?codteor=1006268\&filena me=PL+4106/2012>. Acesso em: 12 nov. 2013.

BRUNO, Eliane Bambini Gorgueira; CHRISTOV, Luiza Helena da Silva. Reuniões na escola: oportunidade de comunicação e saber. In: ___ ; ___ ; ALMEIDA, Laurinda Ramalho de. O coordenador pedagógico e a formação docente. São Paulo: Loyola, 2010. p. 56-64.

CARNEIRO, Isabel Magda Said Pierre; SILVA, Maria Goretti Herculano. Trabalho pedagógico e emancipação humana: a educação profissional à luz da teoria crítica. In: MORAES, Silvia Elizabeth (Org.). Currículo e formação docente: um diálogo interdisciplinar. Campinas, SP: Mercado das Letras, 2008.

CHRISTOV, L. H. S. Teoria e prática: enriquecimento da própria experiência. In: GUIMARÃES, A. A. O Coordenador pedagógico e a educação continuada. São Paulo: Loyola, 2010. p. 31-43.

COÊLHO, Ildeu Moreira. Escritos sobre o sentido da escola: uma introdução. Campinas, SP: Mercado das Letras, 2012.

CONTRERAS, José. A autonomia de professores. Tradução Sandra Trabucco Valenzuela. São Paulo: Cortez, 2002.

CURY, Carlos Roberto Jamil. Educação e contradição: elementos metodológicos para uma teoria crítica do fenômeno educativo. São Paulo: Cortez, 1985.

Os conselhos de educação e a gestão dos sistemas. In: AGUIAR, Márcia Angela da S.; FERREIRA, Naura Syria Carapeto. Gestão da educação: impasses, perspectivas e compromissos. São Paulo: Cortez, 2000. p. 43-60.

DELORS, J. Educação: um tesouro a descobrir. São Paulo: Cortez, 1999.

DIDONET, Vital. Plano nacional de educação. Brasília: Editora Plano, 2000.

DISTRITO FEDERAL (Brasil). Fundação Educacional do Distrito Federal. Departamento de Pedagogia. Coordenação pedagógica. Brasília, 1996. (Caderno da Escola Candanga: diretrizes operacionais, n. 1). 
Lei n. 4.075, de 28 de dezembro de 2007. Dispõe sobre a Carreira Magistério Público do Distrito Federal e dá outras providências. Diário Oficial do Distrito Federal, Poder Executivo, Brasília, DF, 31 dez. 2007. Seção 1, p. 3.

Lei $\mathrm{n}^{\circ}$ 5.105, de 03 de maio de 2013. Reestrutura a carreira Magistério Público do Distrito Federal e dá outras providências. Diário Oficial do Distrito Federal, Poder Executivo, Brasília, DF, 06 maio 2013a. Seção 1, p. 1. Disponível em:

$<$ http://www.cre.se.df.gov.br/ascom/documentos/legis/lei_5105_3mai13.pdf>. Acesso em: 10 nov. 2013.

Secretaria de Educação e Cultura. Coordenação de Educação Primária. Ensino Primário no Distrito Federal. Brasília, DF, 1969.

. Secretaria de Estado de Educação. Orientação pedagógica: projeto políticopedagógico e coordenação pedagógica nas escolas. Brasília, 2014.

Secretaria de Estado de Educação. Portaria no 29, de 20 de janeiro de 2013. Dispõe sobre os critérios para Distribuição de Carga Horária, os procedimentos para a escolha de turmas e para o desenvolvimento das atividades de coordenação pedagógica e, ainda, os quantitativos de Coordenadores Pedagógicos Locais, para os servidores da Carreira Magistério Público do Distrito Federal em exercício nas unidades escolares da rede pública de ensino do Distrito Federal. Diário Oficial do Distrito Federal, Poder Executivo, Brasília, DF, 01 fev. 2013b. Seção 1, p. 10. Disponível em:

<http://www.buriti.df.gov.br/ftp/diariooficial/2013/02_Fevereiro/DODF\%20N\%C2\%BA\%20 026\%2001-02-2013/Se\%C3\%A7\%C3\%A3o01-\%20026.pdf>. Acesso em: 15 nov. 2013.

Secretaria de Estado de Educação. Portaria nº 34, de 05 de fevereiro de 2013.

Estabelece a distribuição dos Supervisores das Unidades Escolares da Secretaria de Estado de Educação do Distrito Federal e dá outras providências. Diário Oficial do Distrito Federal, Poder Executivo, Brasília, DF, 07 fev. 2013c. Seção 1, p. 11. Disponível em: <http://www.buriti.df.gov.br/ftp/diariooficial/2013/02_Fevereiro/DODF\%20N\%C2\%BA\%20 030\%2007-02-2013/Se\%C3\%A7\%C3\%A3o01-\%20030.pdf>. Acesso em: 11 nov. 2013.

Secretaria de Estado de Educação. Projeto Político Pedagógico Professor Carlos Mota. Brasília, 2012. Disponível em: <http://www.se.df.gov.br/wpcontent/uploads/ppp.PDF>. Acesso em: 10 nov. 2013.

Secretaria de Estado de Educação. Regimento Escolar das Instituições Educacionais da Rede Pública de Ensino do Distrito Federal. 5. ed. Brasília, 2009.

DUARTE, Newton. Conhecimento tácito e conhecimento escolar na formação do professor (por que Donald Schön não entendeu Luria). Educação \& Sociedade, Campinas, v. 24, n. 83, p. 601-625, 2003.

FERNANDES, R. C. A. Educação continuada de professores no espaço-tempo da coordenação pedagógica: avanços e tensões. In: VEIGA, Ilma Passos Alencastro; SILVA, Edileuza Fernandes da (Orgs.). A escola mudou. Que mude a formação de professores! Campinas, SP: Papirus, 2012. p. 83-114. 
Educação continuada, trabalho docente e coordenação pedagógica: uma teia tecida por professores e coordenadores. 2007. 202 f. Dissertação (Mestrado em Desenvolvimento Profissional Docente)-Faculdade de Educação, Universidade de Brasília, Brasília, 2007.

FERREIRA, Evandson Paiva. Educação, escola e cultura democrática. In: COÊLHO, Ildeu Moreira. Escritos sobre o sentido da escola: uma introdução. Campinas, SP: Mercado das Letras, 2012. p. 189-208.

FRANCO, Maria Laura Puglisi Barbosa. Análise de conteúdo. Brasília: Líber Livro, 2008.

FURTADO, Rita Márcia Magalhães. O sentido da escola no contexto educacional contemporâneo. In: COÊLHO, Ildeu Moreira. Escritos sobre o sentido da escola: uma introdução. Campinas, SP: Mercado das Letras, 2012. p. 15-32.

FUSARI, José Cerchi. Formação continuada de educadores na escola e em outras situações. In: BRUNO, Eliane Bambini Gorgueira; CHRISTOV, Luiza Helena da Silva; ALMEIDA, Laurinda Ramalho de. O coordenador pedagógico e a formação docente. São Paulo: Loyola, 2010. p. 17-24.

GARRIDO, Elsa. Espaço de formação continuada para o professor coordenador. In: BRUNO, Eliane B.; ALMEIDA, Laurinda R.; CHRISTOV, Luiza. H. (Orgs.). O coordenador pedagógico e a formação docente. São Paulo: Loyola, 2011.

GIL, Antonio Carlos. Estudo de caso. São Paulo: Atlas, 2009.

GONZÁLEZ REY, Fernando Luís. Pesquisa qualitativa e subjetividade: os processos de construção da informação. Tradução Marcel Aristides Ferrada Silva. 2. ed. São Paulo: Cengage Learning, 2005.

GOUVEIA, B.; PLACCO, V. M. N. S. A formação permanente, o papel do coordenador pedagógico e a rede colaborativa. In: ALMEIDA, L. R.; PLACCO, V. M. N. S. $O$ coordenador pedagógico e a formação centrada na escola. São Paulo: Loyola, 2013. p. 6980 .

GUIMARÃES, Ged. A escola como projeto de emancipação do homem. In: COÊLHO, Ildeu Moreira. Escritos sobre o sentido da escola: uma introdução. Campinas, SP: Mercado das Letras, 2012. p. 127-138.

IMBERNÓN, F. Formação docente e profissional: formar-se para a mudança e a incerteza. 6. ed. São Paulo: Cortez, 2010.

JIMENEZ, Susana Vasconcelos; MAIA, Osterne. A chave do saber: um exame crítico do novo paradigma educacional concebido pela ONU. In: SANTOS, Deribaldo et al. Trabalho, educação e luta de classes: a pesquisa em defesa da História. Fortaleza, CE: Brasil Tropical, 2013.

LESSA, Sérgio. Trabalho e proletariado no capitalismo contemporâneo. São Paulo: Cortez, 2011.

; TONET, Ivo. Introdução à filosofia de Marx. São Paulo: Expressão Popular, 2008. 
LIMA, Elma Corrêa de. Um olhar histórico sobre a supervisão pedagógica. In: RANGEL, Mary. Supervisão pedagógica: princípios e práticas. 12. ed. Campinas, SP: Papirus, 2013.

LOMBARDI, José Claudinei; SAVIANI, Dermeval (Orgs.). Marxismo e educação: debates contemporâneos. 2. ed. Campinas, SP: Autores Associados, 2008.

LÜDKE, Menga; ANDRÉ, Marli E. D. A. Pesquisa em educação: abordagens qualitativas. São Paulo: EPU, 1986.

MARX, Karl. O capital. São Paulo: Ciências Humanas, 1983. Cap. V.

MELLO, G. N. de. Magistério de $1^{\circ}$ grau. São Paulo: Cortez; Autores Associados, 1982.

MÉSZÁROS, I. A educação para além do capital. Tradução Isa Tavares. 2. ed. ampl. Campinas, SP: Unicamp; São Paulo: Boitempo, 2012.

MINAYO, Maria Cecília de Souza. Pesquisa social: teoria, método e criatividade. 30. ed. Petrópolis, RJ: Vozes, 2011.

MORAES, M. C. M. de (Org.). Iluminismo às avessas: produção do conhecimento e políticas de formação docente. Rio de Janeiro: DP\&A, 2003.

; TORRIGLIA, P. L. Sentidos de ser docente e da construção de seu conhecimento. In: MORAES, M. C. M. de (Org.). Iluminismo às avessas: produção do conhecimento e políticas de formação docente. Rio de Janeiro: DP\&A, 2003. cap. 2, p. 45-60.

MUNDIM, Elisângela Duarte. A constituição do sujeito coordenador pedagógico: processos e interações. 2011. 147 f. Dissertação (Mestrado)-Programa de Pós-Graduação em Educação, Faculdade de Educação, Universidade de Brasília, Brasília, 2011.

NEVES, Fátima Maria. O ensino mútuo e o método de Lancaster na lei de 1827. In: MACHADO, Maria Cristina Gomes; OLIVEIRA, Terezinha (Orgs.). Educação na história. São Luís, MA: Ed. UEMA, 2008. v. 1, p. 97-118.

NÓVOA, Antônio. Professores imagens do futuro presente. Lisboa: EDUCA Instituto de Educação Universidade de Lisboa, 2011.

ORSOLON, L. A. M. O coordenador/formador como um dos agentes de transformação da/na escola. In: ALMEIDA, L. R.; PLACCO, V. M. N. S. O coordenador pedagógico e o espaço da mudança. São Paulo: Loyola, 2001. p. 8-17.

PLACCO, V. M. N. S.; SILVA, S. H. S. A formação do professor: reflexões, desafios, perspectivas. In: BRUNO, E. B. G.; ALMEIDA, L. R.; CHRISTOV, L. H. S. (Orgs.). $O$ coordenador pedagógico e a formação docente. 6. ed. São Paulo: Loyola, 2011.

QUIXADÁ VIANA, C. M. Q.; ARAGÃO, P. F. S. O curso de especialização em gestão escolar do programa nacional escola de gestores: relato de uma experiência. In: SANTOS, Gilberto Lacerda (Org.). Educação a distância e gestores escolares: subsídios para avaliação de uma política pública. Brasília: Líber Livro, 2014. 
RABELO, Jackeline; RIBEIRO, Luís Távora Furtado. A problemática da formação de professores e a crise do capital: grandes interesses em jogo. In: MENEZES, Ana Maria Dorta de (Org.). Trabalho sociabilidade e educação: uma crítica à ordem do capital. Fortaleza: Editora UFC, 2003.

SANTOMÉ, Jurjo Torres. Globalização e interdisciplinaridade: o currículo integrado. Tradução Cláudia Schilling. Porto Alegre: Artes Médicas, 1998.

SAVIANI, Dermeval. A supervisão educacional em perspectiva histórica: da função à profissão pela mediação da ideia. In: FERREIRA, Naura Syria Carapeto (Org.). Supervisão educacional para uma escola de qualidade: da formação a ação. São Paulo: Cortez, 2002. cap. 1, p.13-38.

. Escola e democracia. São Paulo: Cortez, 1988.

O trabalho como princípio educativo frente às novas tecnologias. Novas tecnologias, trabalho e educação: um debate multidisciplinar. Petrópolis, RJ: Vozes, 1994. p. 147-164.

Pedagogia histórico-crítica. Campinas, SP: Autores Associados, 2012.

; DUARTE, Newton. Pedagogia histórico-crítica e lutas de classe. Campinas, SP: Autores Associados, 2012.

SILVA, Margarida Montejano; DE SORDI, Mara Regina Lemes. A organização do trabalho pedagógico: limites e possibilidades do curso de pedagogia. In: REUNIÃO ANUAL DA ASSOCIAÇÃO NACIONAL DE PÓS-GRADUAÇÃO E PESQUISA EM EDUCAÇÃO, 29., Caxambu. Anais... Caxambu, MG: ANPEd, 2006. GT08.

SOARES, Andrey Felipe Cé. Coordenação pedagógica: ações, legislação, gestão e a necessidade de uma educação estética. Curitiba, PR: CRV, 2012.

SOUSA, José Vieira de. A identidade do sujeito social, ético e político e o projeto pedagógico da escola. In. VEIGA, Ilma Passos de Alencastro; FONSECA, Marília. As dimensões do projeto político pedagógico. Campinas, SP: Papirus, 2012.

Avanços e recuos na implantação do projeto político-pedagógico em rede de ensino. In: VEIGA, Ilma Passos de Alencastro; RESENDE, Lúcia Maria Gonçalves. Escola: espaço do projeto político-pedagógico. Campinas, SP: Papirus, 2008.

SOUZA JÚNIOR, Justino de. Politecnia e omnilateralidade em Marx. Trabalho \& Educação, Belo Horizonte, n. 5, p. 98-115, jan./jun. 1999.

SOUZA, V. L. T. Diferentes aprendizagens do coordenador pedagógico. In: ALMEIDA, Laurinda Ramalho de; PLACCO, Vera Nigro de Souza. O coordenador pedagógico e o atendimento à diversidade. São Paulo: Loyola, 2010.

; PLACCO, V. M. N. S. Diferentes aprendizagens do coordenador pedagógico. In: ALMEIDA, L. R.; PLACCO, V. M. N. S. O coordenador pedagógico e o atendimento à diversidade. São Paulo: Loyola, 2010. p. 47-62. 
; __ Entraves da formação centrada na escola: possibilidades de superação pela parceria da gestão na formação. In: ALMEIDA, L. R.; PLACCO, V. M. N. S. O coordenador pedagógico e a formação centrada na escola. São Paulo: Loyola, 2013. p. 25-44.

; __ O coordenador pedagógico, a questão da autoridade e da formação de valores. In: ALMEIDA, L. R.; PLACCO, V. M. N. S. O coordenador pedagógico e questões da contemporaneidade. São Paulo: Loyola, 2011. p. 25-40.

THERRIEN, Jacques. Docência profissional: a prática de uma racionalidade pedagógica em tempos de emancipação de sujeitos. In: D’ÁVILA, Cristina; VEIGA, Ilma Passos Alencastro. Didática e docência na educação superior: implicações para a formação de professores. Campinas, SP: Papirus, 2012.

TONET, Ivo. Educação, cidadania e emancipação humana. Ijuí, RS: Unijuí, 2005a.

. Educação e emancipação humana. 2005. 207 f. Tese (Doutorado em Filosofia)Faculdade de Filosofia e Ciências, Universidade do Estado de São Paulo, Marília, 2005b.

TRIVIÑOS, Augusto N. S. Introdução à pesquisa em ciências sociais: a pesquisa qualitativa em educação. São Paulo: Atlas, 2012.

VÁZQUEZ, A. S. Filosofia da práxis. 2. ed. Rio de Janeiro: Paz e Terra, 1977.

VEIGA, Ilma Passos Alencastro. A aventura de formar professores. Campinas, SP: Papirus, 2012.

VEIGA, Ilma Passos Alencastro; QUIXADÁ VIANA, Cleide M. Q. Formação de professores: um campo de possibilidades inovadoras. In: VEIGA, Ilma Passos Alencastro; SILVA, Edileuza Fernandes da (Orgs.). A escola mudou. Que mude a formação de professores! Campinas, SP: Papirus, 2012. p. 13-34.

VILLELA, F. C. B.; GUIMARÃES, A. A. Sobre o diagnóstico. In: BRUNO, Eliane Bambini Gorgueira; CHRISTOV, Luiza Helena da Silva; ALMEIDA, Laurinda Ramalho de. $O$ coordenador pedagógico e a formação docente. São Paulo: Loyola, 2010. p. 51-62.

YIN, R. K. Estudo de caso: planejamento e métodos. Tradução Daniel Grassi. 4. ed. Porto Alegre: Bookman, 2010.

ZEICHNER, Kenneth M. Para além da divisão entre professor-pesquisador e pesquisador acadêmico In: GERALDI, Corinta M.; FIORENTINI, Dario; PEREIRA, Elisabete M. (Orgs.). Cartografia do trabalho docente: professor(a)-pesquisador(a). Campinas, SP: Mercado de Letras/ABL, 1998. p. 207-236. 


\section{APÊNDICES}

\section{APÊNDICE A - Termo de consentimento livre e esclarecido}

\section{4 \\ UNIVERSIDADE DE BRASÍLIA - UnB \\ FACULDADE DE EDUCAÇÃO \\ PROGRAMA DE PÓS-GRADUAÇÃO EM EDUCAÇÃO \\ TERMO DE CONSENTIMENTO LIVRE E ESCLARECIDO}

Título da Pesquisa: A formação continuada docente no espaçotempo da coordenação pedagógica

Prezado(a) Professor(a)/Coordenador(a) você está sendo convidado a participar de uma pesquisa que será desenvolvida como parte dos requisitos exigidos para a obtenção do título de Mestre em Educação pela Faculdade de Educação da Universidade de Brasília FE/UnB. Tal pesquisa tem por objetivo analisar as contribuições que a formação continuada docente desenvolvida pelos coordenadores pedagógicos locais no espaço/tempo da coordenação pedagógica oferece para os professores dos anos iniciais.

Para efetivação deste estudo serão realizadas entrevistas semiestruturadas com os coordenadores das duas instituições responsáveis pela formação docente no espaço/tempo da coordenação pedagógica e serão aplicados questionários que facilitarão a expressão da maior quantidade de informações possíveis por parte dos professores regentes das duas instituições que participam da formação desenvolvida pelos coordenadores pedagógicos no espaço/tempo da coordenação pedagógica. Estes encontros poderão ser filmados ou gravados.

Vale ressaltar que a sua participação é voluntária sendo resguardada a liberdade de recusar-se a participar da pesquisa ou solicitar a retirada do seu consentimento em qualquer momento da pesquisa, sem que lhe implique qualquer tipo de prejuízo.

É importante esclarecer que os participantes não correrão riscos uma vez que as informações colhidas durante a pesquisa serão tratadas de forma confidencial, garantindo assim o anonimato de cada participante.

A pesquisadora se compromete a prestar quaisquer esclarecimentos que se façam necessário no início e durante o curso da pesquisa.

Os dados obtidos e analisados serão mantidos com os pesquisadores e serão utilizados tão somente para fins científicos, sempre que necessário para a divulgação do conhecimento.

Brasília, 10 de fevereiro de 2014.

Josimara Xavier

Mestranda em educação - FE/UnB
Cleide Maria Quevedo Quixadá Viana Prof ${ }^{a}$. Orientadora FE/UnB

\section{LIVRE CONSENTIMENTO DO PARTICIPANTE}

$\mathrm{Eu}$ RG.

professor(a) da Secretária de Estado da Educação do DF da Escola de Sobradinho, DECLARO que fui esclarecido(a) quanto aos objetivos e procedimentos do estudo pelo(a) pesquisadora Josimara Xavier, bem como de que será mantido sigilo sobre dados que possam me identificar. Dessa forma, AUTORIZO minha participação para fins estritamente científicos nesta pesquisa, bem como a realização das gravações dos encontros, o uso das imagens e áudios para fins de estudo e para publicação em revistas científicas e de formação de profissionais.

Brasília, de de 2014.

\section{Assinatura do participante}


APÊNDICE B - Roteiro para entrevista do coordenador pedagógico

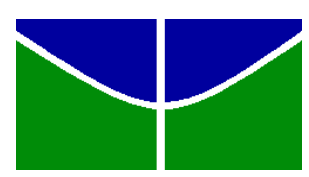

A FORMAÇÃO DOCENTE NO ESPAÇO/TEMPO DA COORDENAÇÃO PEDAGÓGICA

UNIVERSIDADE DE BRASÍLIA

FACULDADE DE EDUCAÇÃO

PROGRAMA DE PÓS-GRADUAÇÃO EM EDUCAÇÃO

\section{GRUPO 1 - COORDENADOR PEDAGÓGICO}

DADOS DOS PARTICIPANTES DA PESQUISA

Nome:

Data de nascimento:

Data de admissão na SEDF:

Área de formação:

Especialização:

Mestrado/Doutorado:

Tempo total na função de coordenador pedagógico:

1 - Motivos importantes que o(a) levaram a ser Coordenador(a) Pedagógico(a).

2 - O que é o espaço/tempo da coordenação pedagógica para você?

3 - Você acredita na possibilidade de haver formação continuada docente nesse espaço/tempo?

4 - O que é formação continuada para você?

5 - Você acha que ela é importante?O que ela possibilita? 
6 - Como era a formação continuada docente no espaço/tempo da coordenação pedagógica antes e como está hoje? (Havia formação? Retrate a realidade na qual você está inserido(a): nível de participação, empenho e comprometimento do grupo, qualidade das relações interpessoais).

7a - Como que você sistematiza a formação nesse tempo e nesse espaço? Tem? Como ela é pensada?

$7 \mathrm{~b}-$ De onde surgem esses temas?

8 - Como você espera que seja a formação continuada no espaço/tempo da coordenação pedagógica?

9 - Você propõe mudanças? Que propostas você já levou para o grupo de professores para que se efetivassem?

10 - Quais as ações implementadas por você para a realização dos momentos formativos no espaço/tempo da coordenação pedagógica?

11 - Qual tem sido sua postura diante das demandas da coordenação pedagógica, incluindo a de formação continuada?

12 - Como você considera sua ação como coordenador pedagógico?

13 - E como você percebe sua atuação enquanto formador dos professores?

14 - Você acredita que participando dessa pesquisa alguma marca ficará em sua vida profissional e pessoal?

15 - Qual a sua perspectiva para o futuro, pretende continuar envolvido com a função de coordenador pedagógico e as questões da formação docente?

16 - O fato de na SEDF não se ter uma formação específica para exercer o papel de coordenador pedagógico isso ajuda ou atrapalha? 
APÊNDICE $\mathrm{C}-1^{\circ}$ questionário aberto para professores regentes

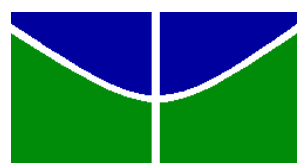

A FORMAÇÃO DOCENTE NO ESPAÇO/TEMPO DA COORDENAÇÃO PEDAGÓGICA

UNIVERSIDADE DE BRASÍLIA

FACULDADE DE EDUCAÇÃO

PROGRAMA DE PÓS-GRADUAÇÃO EM EDUCAÇÃO

$1^{\circ}$ QUESTIONÁRIO ABERTO

GRUPO 2 - PROFESSORES REGENTES

DADOS DOS PARTICIPANTES DA PESQUISA

Nome:

Data de nascimento:

Data de admissão na SEDF:

Área de formação:

Especialização:

Mestrado/Doutorado:

Tempo total na função de professor:

1 - O que significa coordenação pedagógica para você?

2 - Como você vê o espaço/tempo da coordenação pedagógica na sua escola?

3 - Como você gostaria que fosse o espaço da coordenação pedagógica?

4 - Você propõe mudanças ao coordenador pedagógico?

5 - Cite algumas propostas que levaria ao coordenador pedagógico para que as mudanças esperadas por você de fato aconteçam. 
APÊNDICE D - $2^{\circ}$ questionário aberto para professores regentes

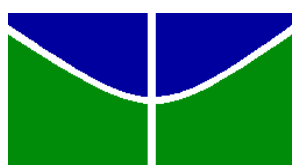 \\ A FORMAÇÃO DOCENTE NO ESPAÇO/TEMPO DA COORDENAÇÃO \\ PEDAGÓGICA \\ UNIVERSIDADE DE BRASÍLIA \\ FACULDADE DE EDUCAÇÃO \\ PROGRAMA DE PÓS-GRADUAÇÃO EM EDUCAÇÃO

\section{GRUPO 2 - PROFESSORES REGENTES} \\ DADOS DOS PARTICIPANTES DA PESQUISA
}

\title{
$2^{\circ}$ QUESTIONÁRIO ABERTO
}

Nome:

1 - Como tem sido sua participação nos momentos de formação continuada realizadas pelo coordenador pedagógico?

2 - Como você percebe a relação dos professores regentes com o coordenador pedagógico?

3 - Como é a sua relação com o coordenador pedagógico?

4 - Durante o tempo da coordenação pedagógica há espaço para a formação continuada docente?

5 - Essa formação tem interferido na sua prática pedagógica? Somente na sua prática ou em outras áreas da sua vida? Explique. 
APÊNDICE $E-3^{\circ}$ questionário aberto para professores regentes e $2^{\circ}$ questionário aberto para coordenadoras pedagógicas

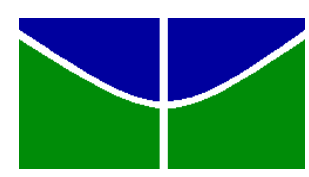

A FORMAÇÃO DOCENTE NO ESPAÇO/TEMPO DA COORDENAÇÃO PEDAGÓGICA

UNIVERSIDADE DE BRASÍLIA

FACULDADE DE EDUCAÇÃO

PROGRAMA DE PÓS-GRADUAÇÃO EM EDUCAÇÃO

\section{$3^{\circ}$ QUESTIONÁRIO ABERTO}

\section{GRUPO 2 - PROFESSORES REGENTES/COORDENADORAS PEDAGÓGICAS}

Nome:

1 - Em termos práticos, como são organizados os momentos da Coordenação Pedagógica na escola? (se achar necessário preencha o quadro)

\begin{tabular}{|l|l|l|}
\hline Terça & Quarta & \\
\hline & & \\
& & \\
& & \\
& & \\
\hline
\end{tabular}

2 - Em termos práticos, como tem acontecido a formação continuada no espaço/tempo da coordenação pedagógica?

3 - Para você, qual é o sentido de tudo o que acontece no espaço/tempo da coordenação pedagógica? 
4 - Qual é a sua concepção de escola? Que função ela exerce na sociedade?

5 - Diante da dinâmica escolar e da "falta de espaço" para a realização dos momentos de formação continuada você pensa ou sugere alternativas e as propõe para a coordenadora pedagógica para que essa formação de fato aconteça? Por quê?

6 - Participar dessa pesquisa te levou a refletir sobre sua profissão, sua atuação como coordenadora pedagógica ou sobre sua trajetória profissional? Fale um pouco sobre o assunto.

Utilize esse espaço para se expressar livremente.

Grata, 
APÊNDICE F - Complemento de frases para professores regentes e coordenadoras pedagógicas

A FORMAÇÃO DOCENTE NO ESPAÇO/TEMPO DA COORDENAÇÃO PEDAGÓGICA UNIVERSIDADE DE BRASÍLIA

FACULDADE DE EDUCAÇÃO

PROGRAMA DE PÓS-GRADUAÇÃO EM EDUCAÇÃO

Momento Crítico-reflexivo

GRUPO 1 - COORDENADORES PEDAGÓGICOS

Nome:

1 - FORMAÇÃO CONTINUADA é...

2 - A FORMAÇÃO CONTINUADA é importante porque...

3 - A FORMAÇÃO CONTINUADA no espaço-tempo da coordenação pedagógica possibilita...

4 - Minha FORMAÇÃO CONTINUADA...

5 - A minha FORMAÇÃO CONTINUADA no meu local de trabalho... 


\title{
APÊNDICE G - $1^{\circ}$ questionário aberto para coordenadoras pedagógicas
}

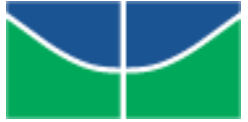 \\ UNIVERSIDADE DE BRASÍLIA \\ FACULDADE DE EDUCAÇÃO \\ PROGRAMA DE PÓS-GRADUAÇÃO EM EDUCAÇÃO \\ PROFESSORA: Dra CLEIDE MARIA QUEVEDO QUIXADÁ VIANA \\ MESTRANDA: JOSIMARA XAVIER

\section{Curso de Pós Graduação stricto sensu em Formação Docente \\ Universidade de Brasília} \\ Faculdade de Educação
}

Este questionário faz parte de uma pesquisa, que resultará na produção de uma dissertação sobre a Formação Docente no espaço/tempo da Coordenação Pedagógica para o curso de Mestrado - realizado pela FE da UnB. As informações obtidas tem o objetivo de coletar dados para responder a questão investigada. Sua contribuição torna-se fundamental! Responda revelando a realidade que vivencia. As informações obtidas serão mantidas em sigilo.

Obrigada pela sua colaboração, JOSIMARA XAVIER

1. Anos na Secretaria de Educação:

2. Tempo na Instituição de Ensino:

3. Tempo na Coordenação Pedagógica:

4. Formação:

a) Graduação:

b) Especialização:

5. Mestrado:

6. Doutorado:

7. Fez algum curso específico de Coordenação Pedagógica? Qual? Onde? Quantas horas/aula?

8. Por que está nessa função?

9. Como você vê a formação no espaço/tempo da coordenação pedagógica? 
10. Tem dificuldades para realizar a formação no espaço/tempo da coordenação pedagógica? Quais?

11. Há ações/suporte da equipe gestora aos coordenadores para a realização da formação continuada no espaço/tempo da Coordenação Pedagógica? Fale a respeito.

12. Deixe aqui algum apontamento, questionamento, desabafo, elogio a respeito da coordenação pedagógica, do seu trabalho de coordenador(a), da formação continuada no espaço/tempo da coordenação pedagógica: 
APÊNDICE $\mathbf{H}-3^{\circ}$ questionário aberto para coordenadores pedagógicos

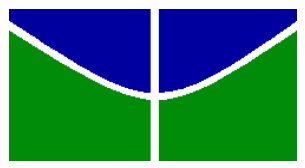

A FORMAÇÃO DOCENTE NO ESPAÇO/TEMPO DA COORDENAÇÃO PEDAGÓGICA

UNIVERSIDADE DE BRASÍLIA

FACULDADE DE EDUCAÇÃO

PROGRAMA DE PÓS-GRADUAÇÃO EMM EDUCAÇÃO

\section{$2^{\circ}$ QUESTIONÁRIO ABERTO}

\section{GRUPO 1 - COORDENADORES PEDAGÓGICOS}

Nome:

1 - Em termos práticos, como você organiza os momentos da coordenação pedagógica na escola? (se achar necessário preencha o quadro abaixo)

\begin{tabular}{|l|l|l|}
\hline Terça & Quarta & Quinta \\
\hline & & \\
& & \\
& & \\
& & \\
\hline
\end{tabular}

2 - Em termos práticos, como você organiza a formação continuada docente no espaço/tempo da coordenação pedagógica?

3 - Para você, qual é o sentido de tudo o que acontece no espaço/tempo da coordenação pedagógica? 
4 - Qual é a sua concepção de escola? Que função ela exerce na sociedade?

5 - Diante da dinâmica escolar e da "falta de espaço" para a realização dos momentos de formação continuada que estratégias são empreendidas por você para que ela de fato aconteça?

6 - Participar dessa pesquisa te levou a refletir sobre sua profissão, sua atuação como coordenadora pedagógica ou sobre sua trajetória profissional? Fale um pouco sobre o assunto.

Grata, 


\title{
APÊNDICE I - Questionário aberto para diretoras
}

\author{
$\checkmark$ \\ UNIVERSIDADE DE BRASÍLIA \\ FACULDADE DE EDUCAÇÃO \\ PROGRAMA DE PÓS-GRADUAÇÃO EM EDUCAÇÃO \\ PROFESSORA: Dra CLEIDE MARIA QUEVEDO QUIXADÁ VIANA \\ MESTRANDA: JOSIMARA XAVIER
}

\section{Curso de Pós Graduação stricto sensu em Formação Docente, Linha de Pesquisa: \\ Profissão Docente, Currículo e Avaliação. \\ Universidade de Brasília}

Faculdade de Educação

Este questionário faz parte de uma pesquisa, que resultará na produção de uma dissertação sobre a Formação Docente no espaço/tempo da Coordenação Pedagógica para o curso de Mestrado - realizado pela FE da UnB. As informações obtidas tem o objetivo de coletar dados para responder a questão investigada. Sua contribuição torna-se fundamental! Responda revelando a realidade que vivencia. As informações obtidas serão mantidas em sigilo.

Obrigada pela sua colaboração, JOSIMARA XAVIER

13. Anos na Secretaria de Educação:

14. Tempo na Instituição de Ensino:

15. Tempo na equipe gestora:

16. Formação:

c) Graduação:

d) Especialização:

e) Mestrado:

f) Doutorado:

17. Fez algum curso específico de Gestão Educacional? Qual? Onde? Quantas horas/aula?

18. Por que está nessa função? 
19. Como você vê a formação no espaço/tempo da coordenação pedagógica?

20. Vê dificuldades para a realização da formação no espaço/tempo da coordenação pedagógica? Quais?

21. Há ações/suporte da equipe gestora aos coordenadores para a realização da formação continuada no espaço/tempo da Coordenação Pedagógica? Fale a respeito.

22. $\mathrm{N}^{\mathrm{o}}$ de Professores de anos iniciais:

23. $\mathrm{N}^{\mathrm{o}}$ de Coordenadores de anos iniciais:

24. $\mathrm{N}^{\mathrm{o}}$ de alunos de anos iniciais:

25. Turno em que são atendidos os alunos dos anos iniciais:

26. Deixe aqui algum apontamento, questionamento, desabafo, elogio a respeito da coordenação pedagógica, do seu trabalho de Gestor(a), da formação continuada no espaço/tempo da coordenação pedagógica, anseios, frustrações, alegrias e esperanças: 
ANEXOS

ANEXO A - Quadro de Planejamento Quinzenal UE 02

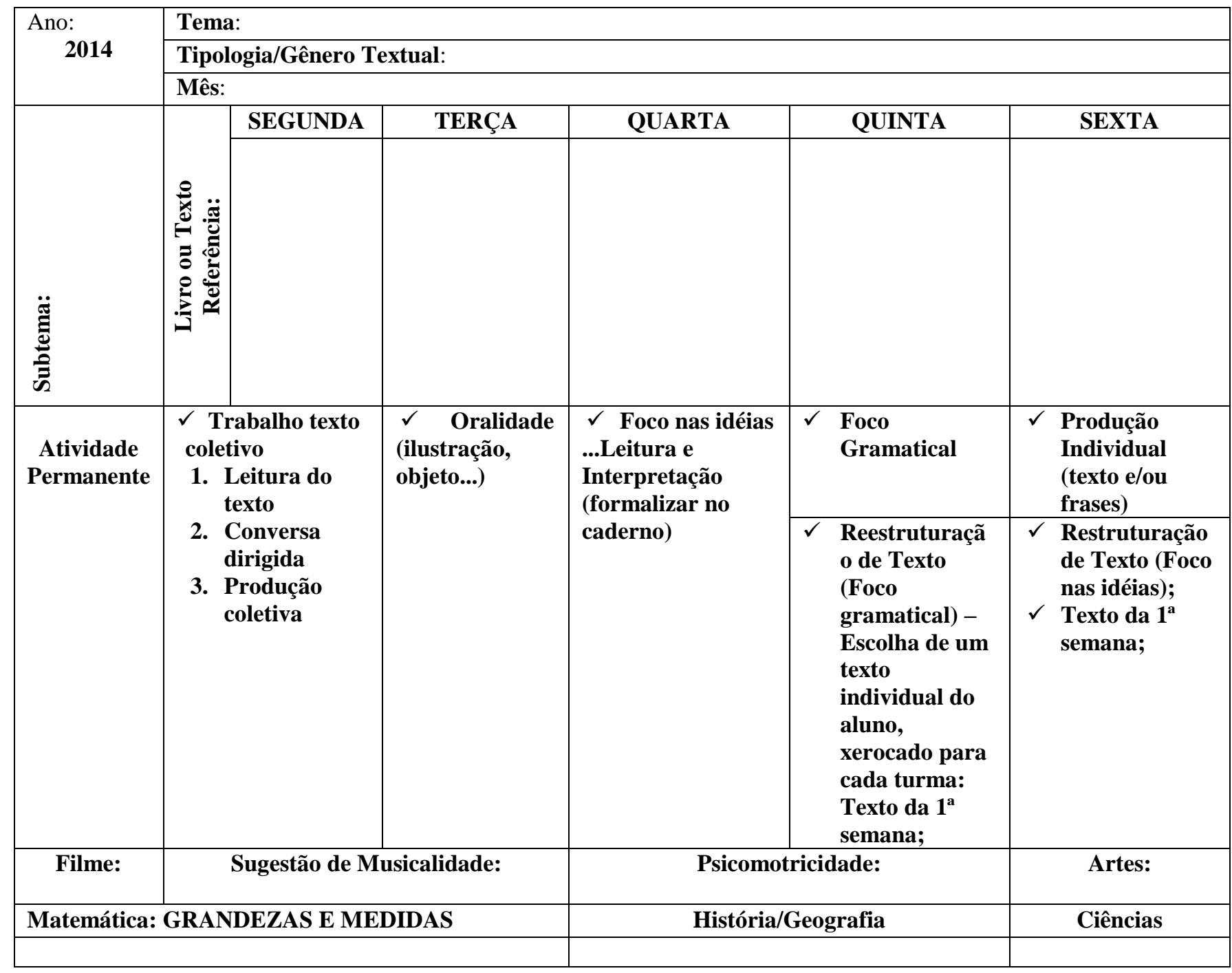

Hora social:

Mural: 
ANEXO B - Quadro de Planejamento Semestral - Matemática/UE 02

\begin{tabular}{|c|c|c|}
\hline \multicolumn{3}{|c|}{$\begin{array}{l}\text { Coordenaçāo Coletiva }-2014 \\
\text { Descritores de Matemática do } 2 \% \text { semestre }\end{array}$} \\
\hline \multirow[t]{2}{*}{ Ano } & Descritores & \multirow{2}{*}{ Período } \\
\hline & Números e operaçōes & \\
\hline 12 Ano & $\begin{array}{l}\text { D2.1 - Resolver problemas que demandam as açōes de juntar, separar, } \\
\text { acrescentar e retirar quantidades. }\end{array}$ & Agosto \\
\hline 29 Ano & $\begin{array}{l}\text { D3.1 - Resolver problemas que envolvam as ideias da multiplicação. } \\
\text { D3.2 - Resolver problemas que envolvam as ideias da divisão. }\end{array}$ & Agosto \\
\hline \multirow[t]{3}{*}{39 Ano } & H8 - Cálculo de adições e subtrações & Agosto \\
\hline & H9 - Resolver problemas que envolvam as ideias de multiplicação & Setembro \\
\hline & H 10- Resolver problemas que envolvam as ideias da divisão & Outubro \\
\hline 49 Ano & $\begin{array}{l}\text { D18 Calcular o resultado de uma multiplicação ou divisão de números } \\
\text { naturais } \\
\text { D19 Resolver problema com números naturais, envolvendo diferentes } \\
\text { significados da adição ou subtração: juntar, alteraçäo de um estado } \\
\text { inicial (positiva ou negativa), comparaçăo e mais de uma transformação } \\
\text { (positiva ou negativa) }\end{array}$ & Agosto \\
\hline 5? Ano & $\begin{array}{l}\text { D14 Identificar a localização de números naturais na reta numérica } \\
\text { D21 Identificar diferentes representaçőes de um mesmo número } \\
\text { racional } \\
\text { D23 Resolver problema utilizando a escrita decimal de cédulas e moedas } \\
\text { do sistema monetário brasileiro } \\
\text { D24 Identificar fração como representação que pode estar associada a } \\
\text { diferentes significados } \\
\text { D26 Resolver problema envolvendo noções de porcentagem }(25 \%, 50 \% \text {, } \\
100 \%)\end{array}$ & Agosto \\
\hline Ano & Geometria/ Espaço e forma & Período \\
\hline i० Ano & D4.1-Identificar figuras geométricas planas. & Setembro \\
\hline 2\% Ano & D4.1-Identificar figuras geométricas planas. & Setembro \\
\hline \multicolumn{3}{|c|}{ 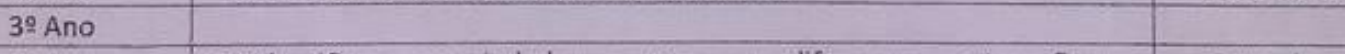 } \\
\hline 4: Ano & $\begin{array}{l}\text { D3 Identificar propriedades comuns e diferenças entre figuras } \\
\text { bidimensionais pelo número de lados, pelos tipos de ângulos }\end{array}$ & Setembro \\
\hline 5:Ano & $\begin{array}{l}\text { D3 Identificar propriedades comuns e diferenças entre figuras } \\
\text { bidimensionais pelo número de lados, pelos tipos de ângulos } \\
\text { D4 Identificar quadriláteros observando as posiçōes relativas entre seus } \\
\text { lados (paralelos, concorrentes, perpendiculares) }\end{array}$ & Setembro \\
\hline Ano & Grandezas e Medidas & Período \\
\hline 12 Ano & $\begin{array}{l}\text { D5.1 - Comparar e ordenar comprimentos } \\
\text { D5.3 - Identificar, comparar, relacionar e ordenar tempo em } \\
\text { diferentes sistemas de medida. }\end{array}$ & Outubro \\
\hline 29 Ano & $\begin{array}{l}\text { D5.1 - Comparar e ordenar comprimentos } \\
\text { D5.2 - Identificar e relacionar cédulas e moedas. }\end{array}$ & Outubro \\
\hline \multicolumn{3}{|c|}{ - } \\
\hline $4^{\circ}$ Ano & $\begin{array}{l}\text { D10 Num problema, estabelecer trocas entre cédulas e moedas do } \\
\text { sistema monetário brasileiro em funçäo de seus valores }\end{array}$ & Agosto \\
\hline S? Ano & $\begin{array}{l}\text { D10 Num problema, estabelecer trocas entre cédulas e moedas do } \\
\text { sistema monetario brasileiro em funçäo de seus valores }\end{array}$ & Agosto \\
\hline
\end{tabular}


ANEXO C - Quadro de Acompanhamento de aluno - Matemática/UE 02

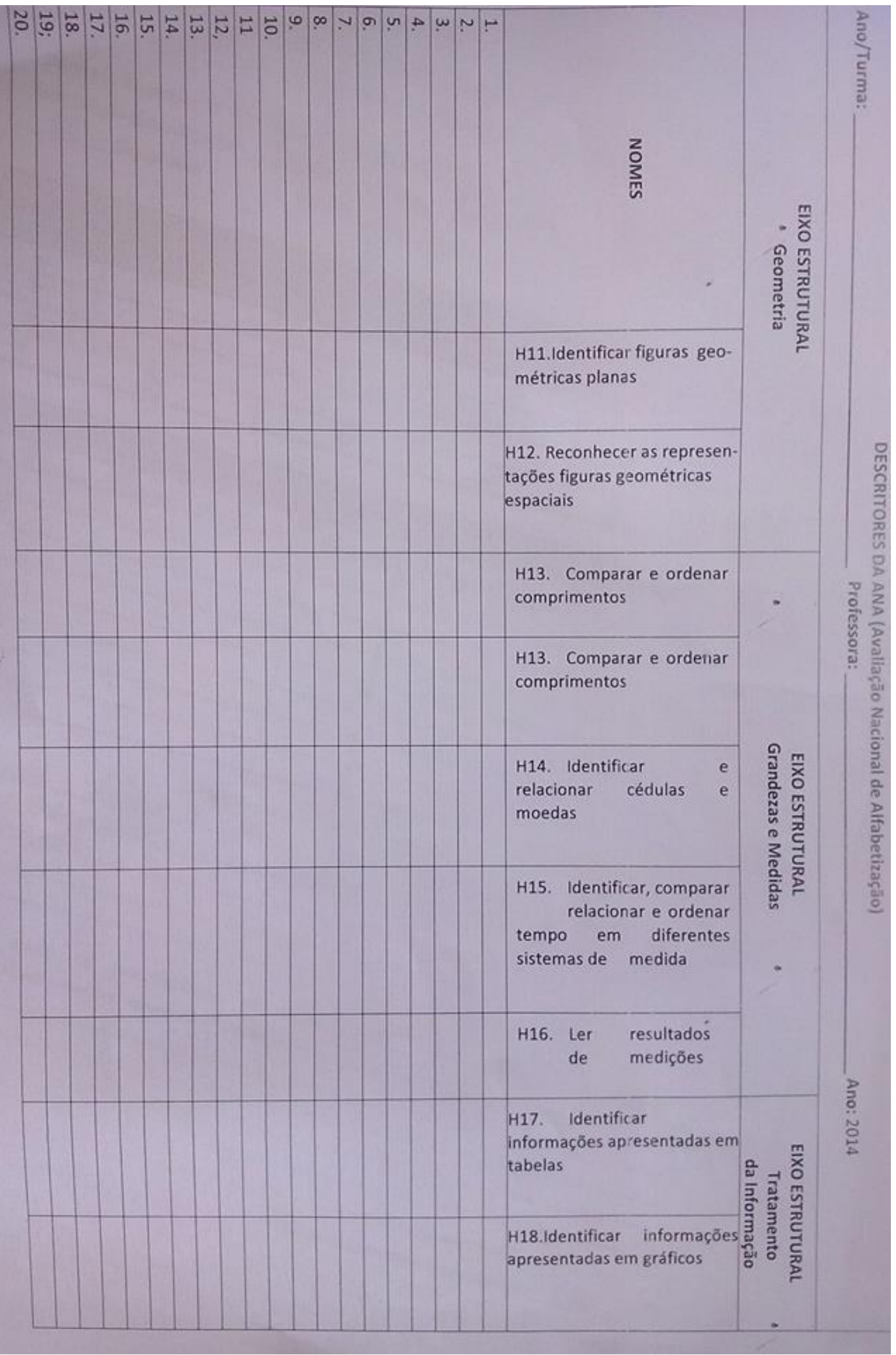


ANEXO D - Quadro de Acompanhamento de aluno - Matemática/UE 02

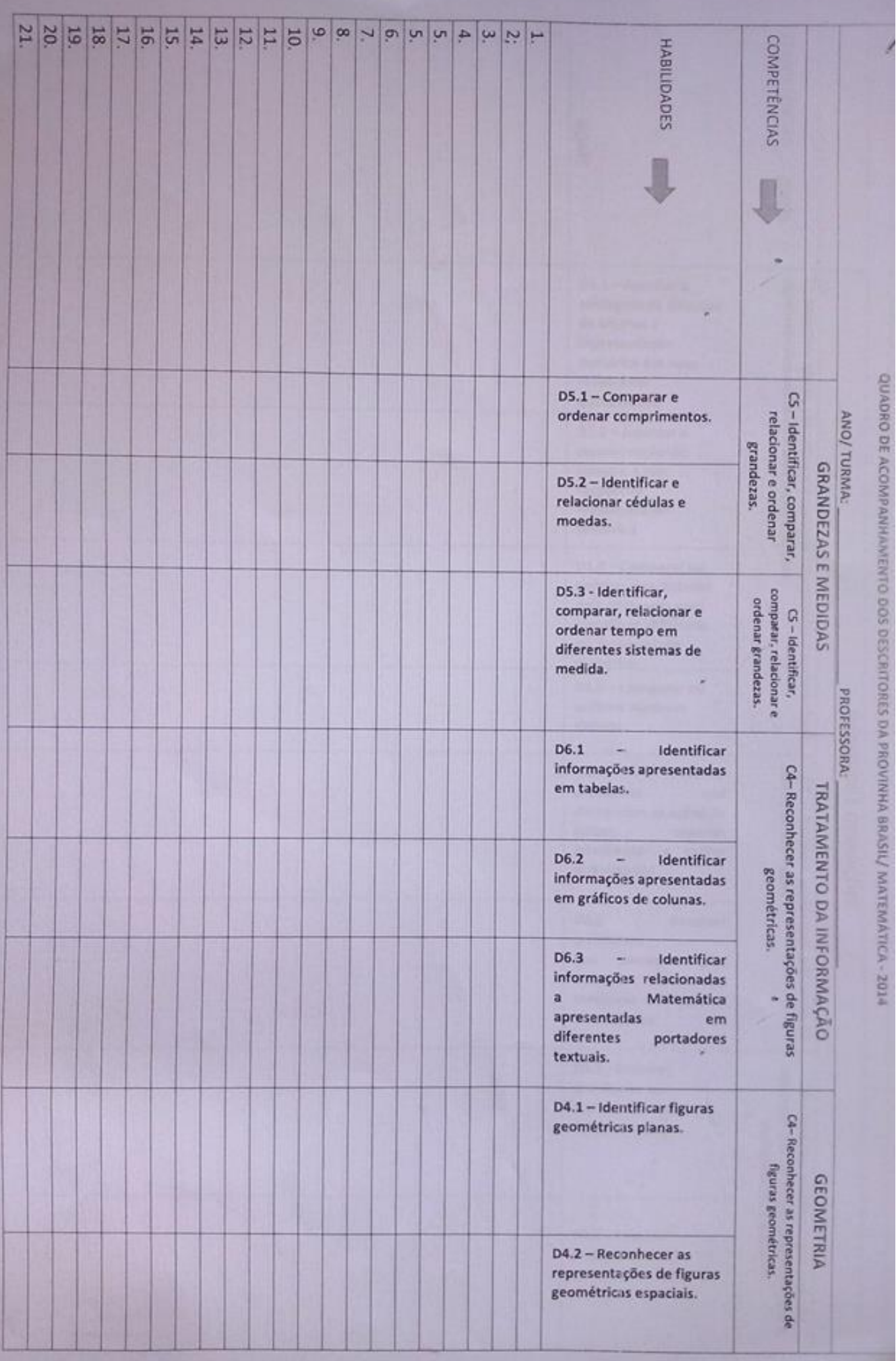


ANEXO E - Quadro de Acompanhamento de aluno - Língua Portuguesa/UE 02

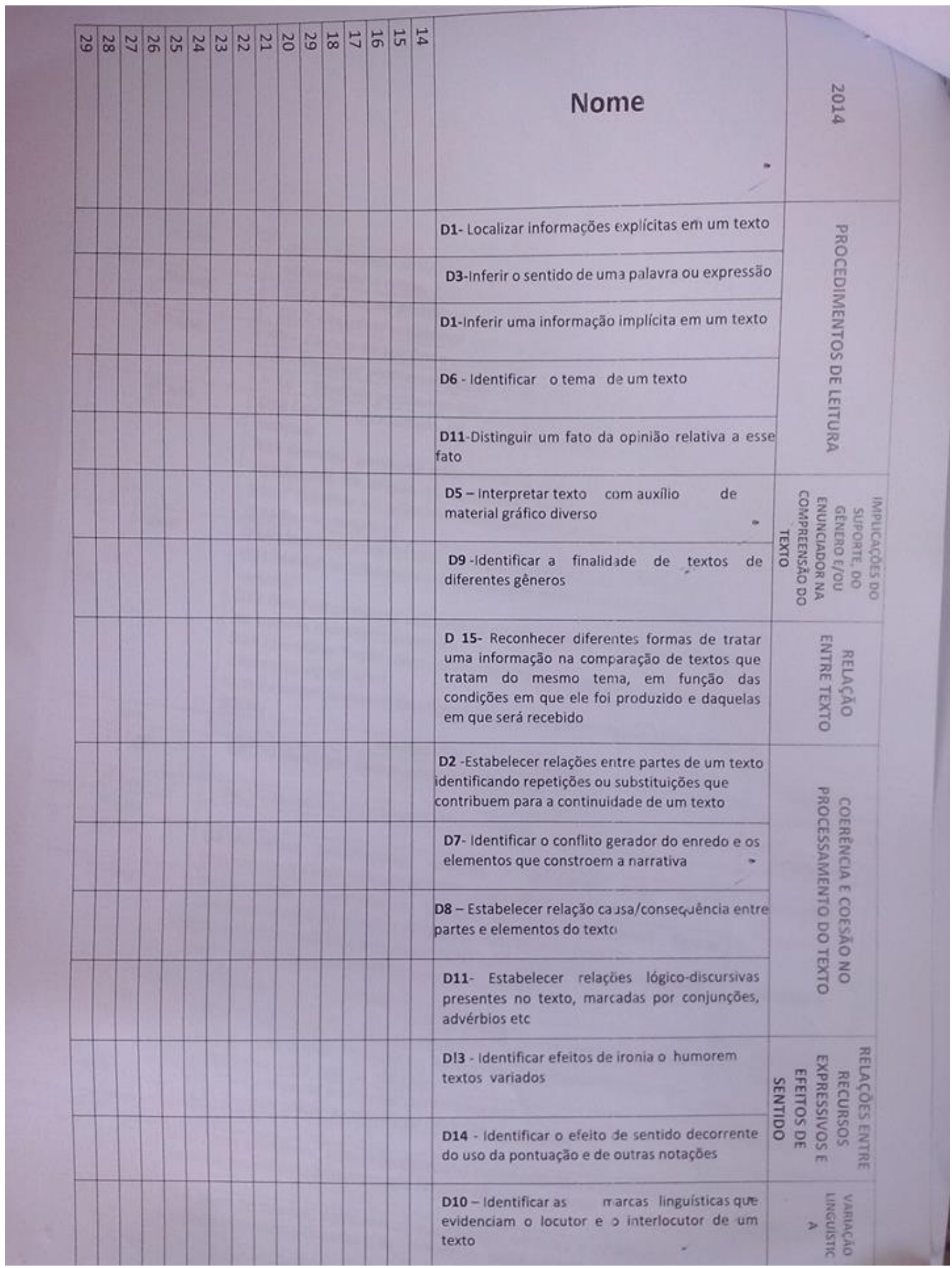


ANEXO F - Formulário para registro de reunião pedagógica UE 01

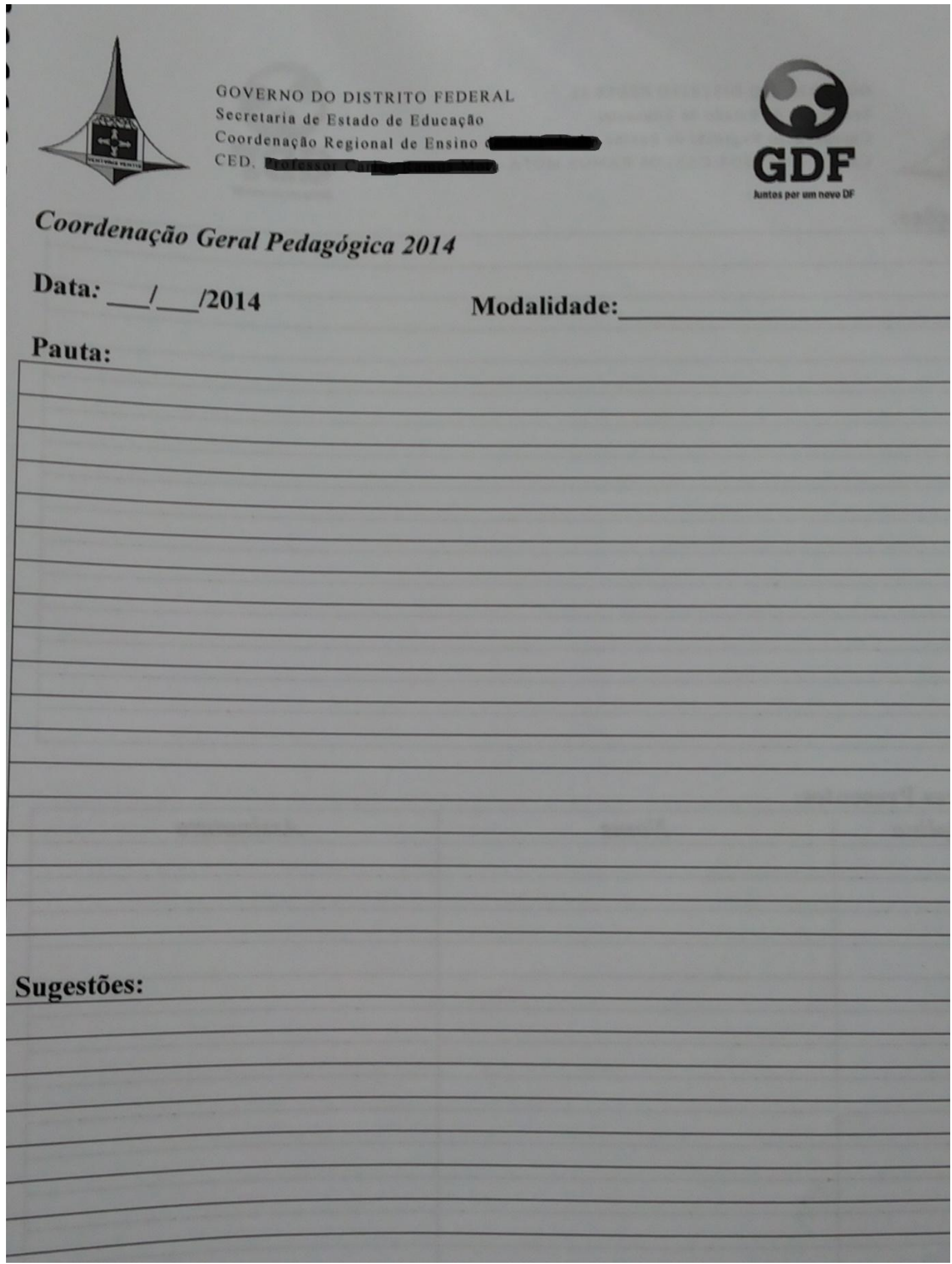




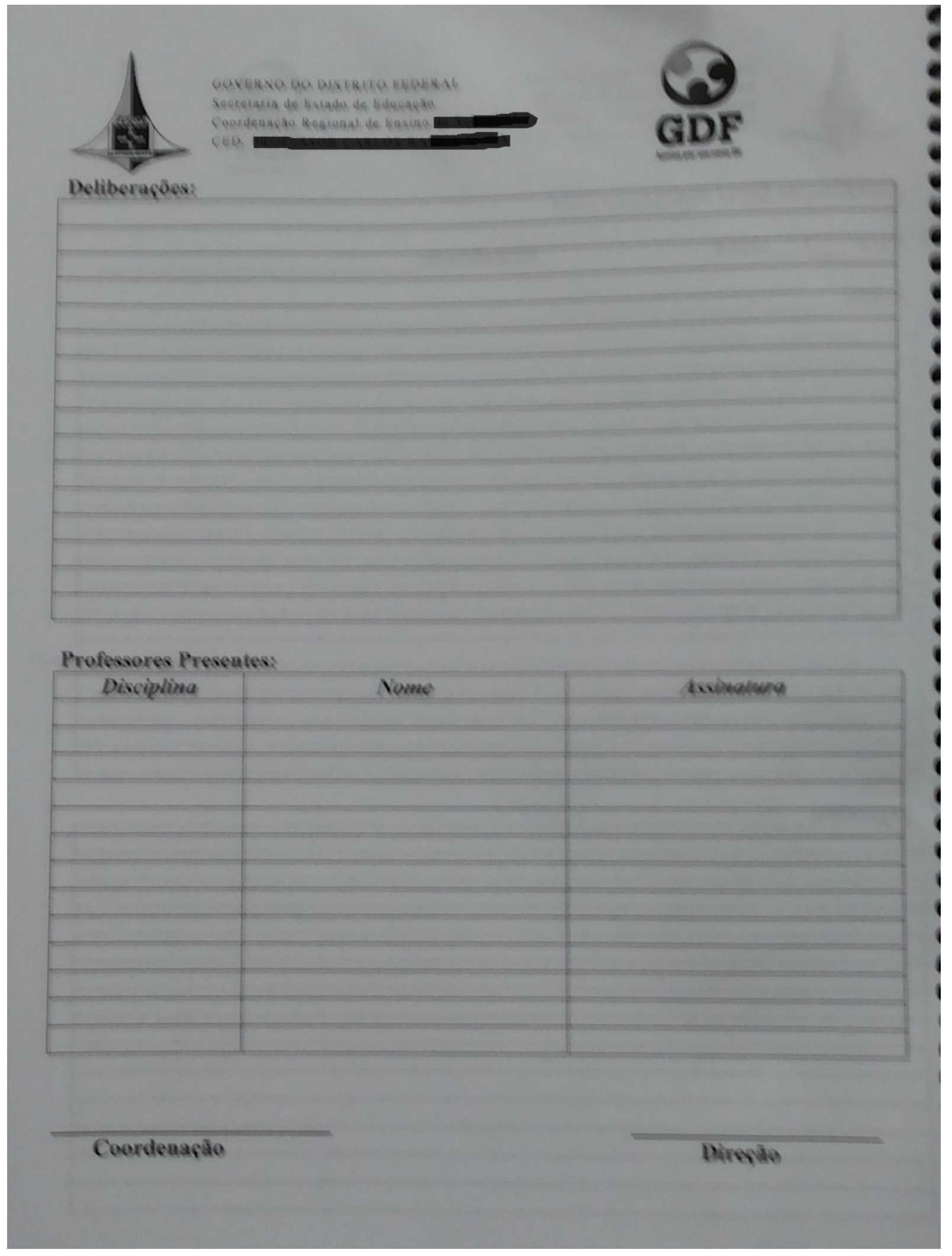

